\title{
Enhanced Component Performance Study: Turbine-Driven Pumps 1998-2014
}

\author{
John A. Schroeder
}

November 2015

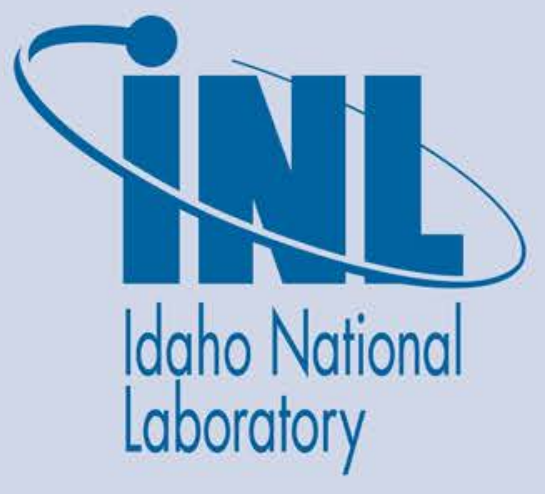

The INL is a U.S. Department of Energy National Laboratory operated by Battelle Energy Alliance 
NOTICE

This information was prepared as an account of work sponsored by an agency of the U.S. Government. Neither the U.S. Government nor any agency thereof, nor any of their employees, makes any warranty, express or implied, or assumes any legal liability or responsibility for any third party's use, or the results of such use, of any information, apparatus, product, or process disclosed herein, or represents that its use by such third party would not infringe privately owned rights. The views expressed herein are not necessarily those of the U.S. Nuclear Regulatory Commission. 


\title{
Enhanced Component Performance Study: Turbine-Driven Pumps 1998-2014
}

\author{
John A. Schroeder
}

Update Completed November 2015

Idaho National Laboratory

Risk Assessment and Management Services Department Idaho Falls, Idaho 83415

http://www.inl.gov

Prepared for the Division of Risk Assessment Office of Nuclear Regulatory Research

U.S. Nuclear Regulatory Commission NRC Agreement Number NRC-HQ-14-D-0018 



\begin{abstract}
This report presents an enhanced performance evaluation of turbine-driven pumps (TDPs) at U.S. commercial nuclear power plants. The data used in this study are based on the operating experience failure reports from fiscal year 1998 through 2014 for the component reliability as reported in the Institute of Nuclear Power Operations (INPO) Consolidated Events Database (ICES). The TDP failure modes considered are failure to start (FTS), failure to run less than or equal to one hour $(\mathrm{FTR} \leq 1 \mathrm{H})$, failure to run more than one hour $(\mathrm{FTR}>1 \mathrm{H})$, and normally running systems FTS and failure to run (FTR). The component reliability estimates and the reliability data are trended for the most recent 10year period while yearly estimates for reliability are provided for the entire active period. Statistically significant increasing trends were identified for TDP unavailability, for frequency of start demands for standby TDPs, and for run hours in the first hour after start. Statistically significant decreasing trends were identified for start demands for normally running TDPs, and for run hours per reactor critical year for normally running TDPs.
\end{abstract}




\section{CONTENTS}

ABSTRACT iii

ACRONYMS ix

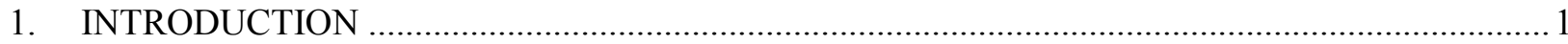

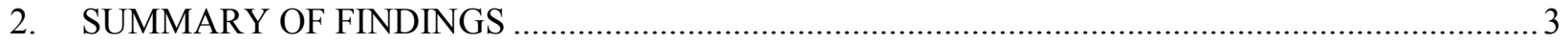

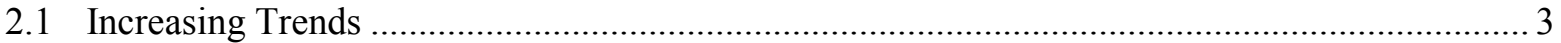

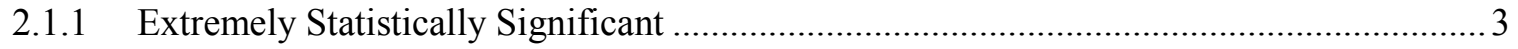

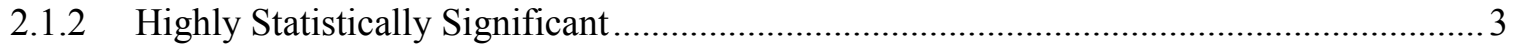

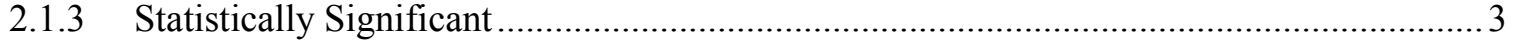

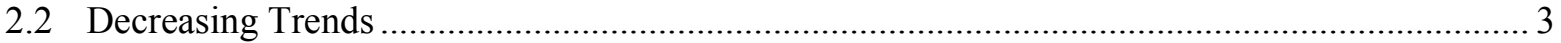

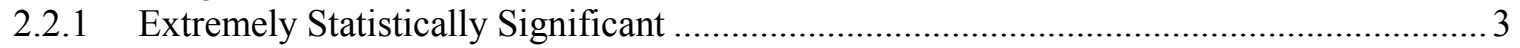

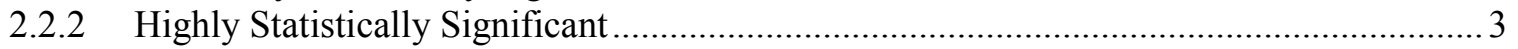

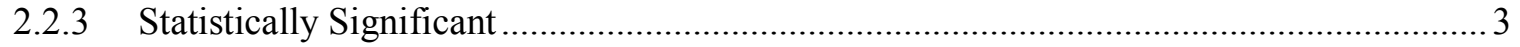

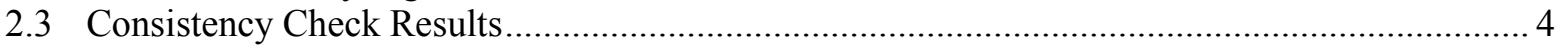

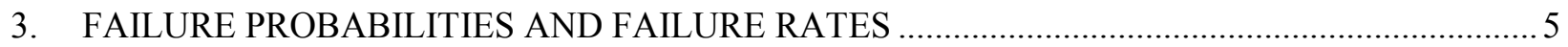

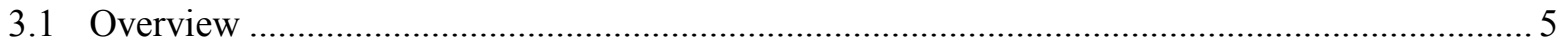

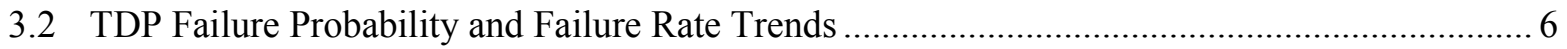

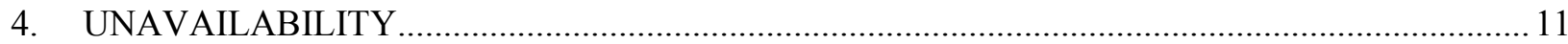

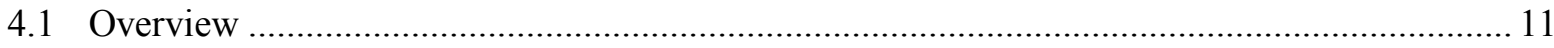

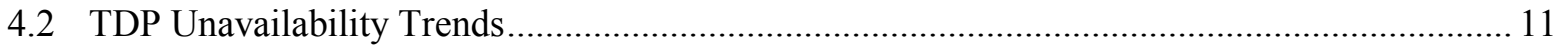

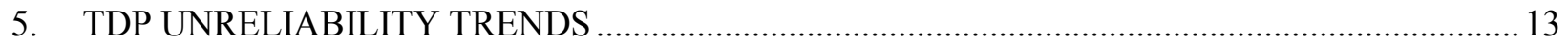

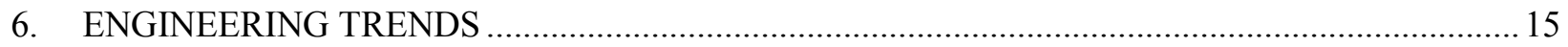

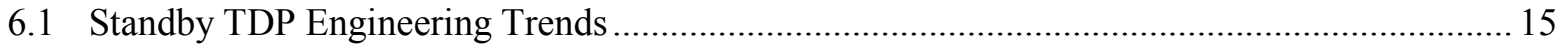

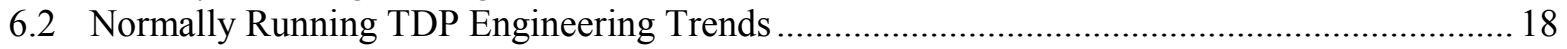

6.3 Comparison of ICES TDP Unplanned Demand Results with Industry Results ........................22

6.4 TDP Engineering Analysis by Failure Modes ...................................................................... 22

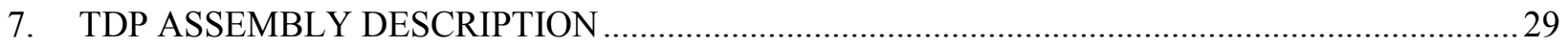

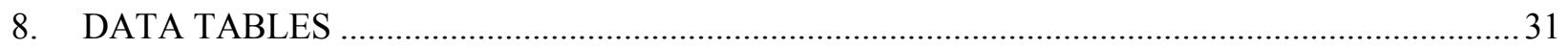

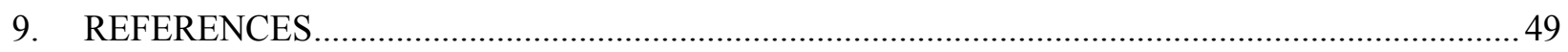




\section{FIGURES}

Figure 1. Failure probability estimate trend for standby systems, industry-wide TDP FTS trend. ............ 7

Figure 2. Failure probability estimate trend for standby systems, industry-wide TDP FTR $\leq 1 \mathrm{H}$ trend.

Figure 3. Failure rate estimate trend for standby systems, industry-wide TDP FTR $>1 \mathrm{H}$ trend. 8

Figure 4. Failure probability estimate trend for normally running systems (MFW), industry-wide TDP FTS trend.

Figure 5. Failure rate estimate trend for normally running systems (MFW), industry-wide TDP FTR trend.

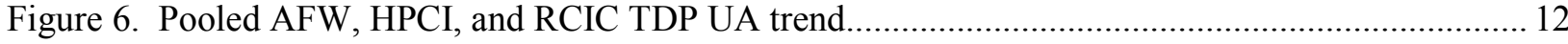

Figure 7. Standby systems, industry-wide TDP unreliability trend (8-hour mission). ........................... 13

Figure 8. Normally running systems, industry-wide TDP unreliability trend (8-hour mission)............... 14

Figure 9. Frequency (events per reactor year) of start demands, standby TDPs................................... 15

Figure 10. Standby TDP run hours per reactor critical year of run $\leq 1 \mathrm{H}$ hours.................................... 16

Figure 11. Standby TDP run hours per reactor critical year. …..................................................... 16

Figure 12. Frequency (events per reactor year) of FTS events, standby TDPs..................................... 17

Figure 13. Frequency (events per reactor year) of FTR $\leq 1 \mathrm{H}$ events, standby TDPs.............................. 17

Figure 14. Frequency (events per reactor year) of FTR $>1 \mathrm{H}$ events, standby TDPs.............................. 18

Figure 15. Frequency (events per reactor year) of start demands, normally running TDPs. .................... 19

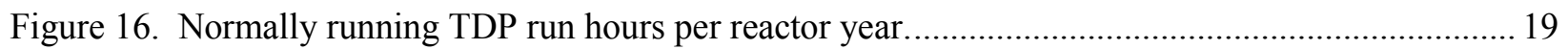

Figure 17. Frequency (events per reactor year) of FTS events, normally running TDPs. ...................... 20

Figure 18. Frequency (events per reactor year) of FTR events, normally running TDPs........................ 20

Figure 19. TDP failure event breakdown by subcomponent, failure mode, and operational status........... 25

Figure 20. TDP failure event breakdown by cause group, failure mode, and operational status.............. 26

Figure 21. TDP failure event breakdown by failure detection method, failure mode, and operational status.

Figure 22. TDP failure event breakdown by recoverability determination, failure mode, and operational status. 


\section{TABLES}

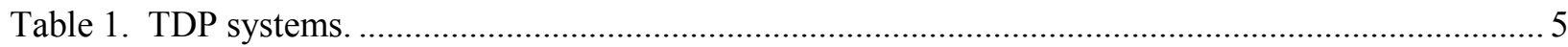

Table 2. Industry-wide distributions of $\mathrm{p}$ (failure probability) and $\lambda$ (hourly rate) for TDPs..................... 5

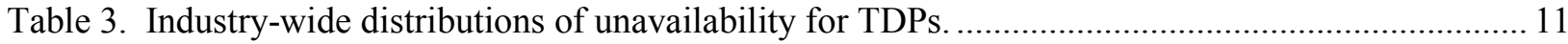

Table 4. Summary of TDP failure counts for the FTS failure mode over time by system. ..................... 21

Table 5. Summary of TDP failure counts for the FTR $\leq 1 \mathrm{H}$ failure mode over time by system................2 21

Table 6. Summary of TDP failure counts for the FTR $>1 \mathrm{H}$ and FTR failure mode over time by

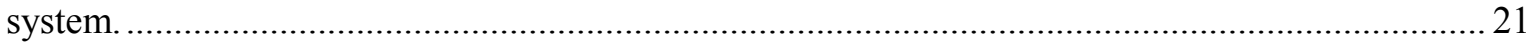

Table 7. Standby TDP unplanned demand performance comparison with industry-average performance.

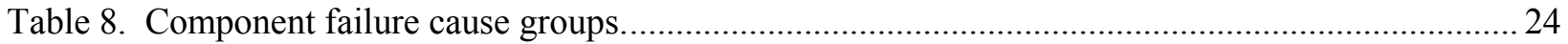

Table 9. Plot data for Figure 1, standby TDP FTS industry trend. ...................................................... 31

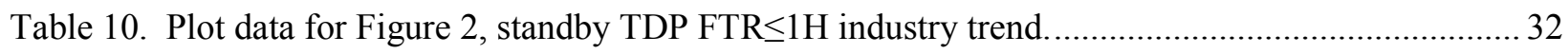

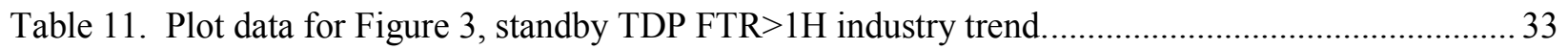

Table 12. Plot data for Figure 4, normally running TDP FTS industry trend....................................... 34

Table 13. Plot data for Figure 5, normally running TDP FTR industry trend. ...................................... 35

Table 14. Plot data for Figure 6, all standby TDP unavailability trend. .............................................. 36

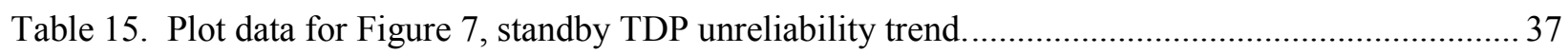

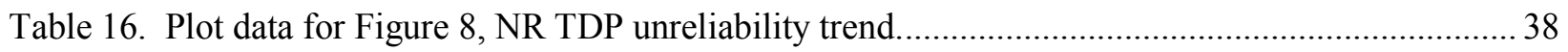

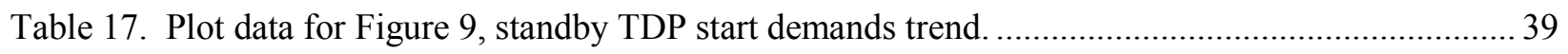

Table 18. Plot data for Figure 10, standby TDP run $\leq 1$ hour run-hours trend ....................................... 40

Table 19. Plot data for Figure 11, standby TDP run $>1$ hour run-hours trend...................................... 41

Table 20. Plot data for Figure 12, standby TDP FTS events trend.................................................... 42

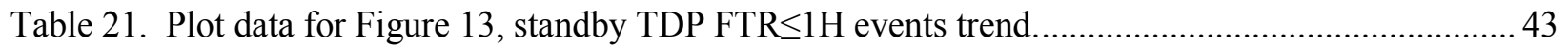

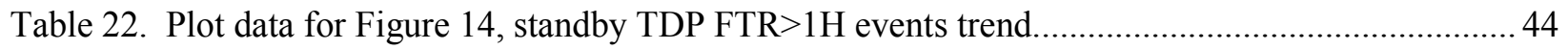

Table 23. Plot data for Figure 15, normally running TDP start demands trend....................................45

Table 24. Plot data for Figure 16, normally running TDP run hours trend.......................................... 46 
Table 25. Plot data for Figure 17, normally running TDP FTS events trend....................................... 47

Table 26. Plot data for Figure 18, normally running TDP FTR events trend. ....................................... 48 


\section{ACRONYMS}

\begin{tabular}{|c|c|}
\hline CNID & constrained non-informative prior distribution \\
\hline EPIX & Equipment Performance and Information Exchange \\
\hline EPS & emergency power supply \\
\hline ESF & engineered safety feature \\
\hline GLM & Generalized linear model \\
\hline $\mathrm{FTR} \leq 1 \mathrm{H}$ & failure to run less than or equal to one hour \\
\hline $\mathrm{FTR}>1 \mathrm{H}$ & failure to run greater than one hour \\
\hline FTR & failure to run \\
\hline FTS & failure to start \\
\hline FY & fiscal year \\
\hline HPCS & high-pressure core spray \\
\hline ICES & INPO Consolidated Events Database \\
\hline INPO & Institute of Nuclear Power Operations \\
\hline MSPI & Mitigating Systems Performance Index \\
\hline PRA & probabilistic risk assessment \\
\hline TDP & turbine-driven pump \\
\hline UA & unavailability \\
\hline
\end{tabular}




\section{Enhanced Component Performance Study: Turbine-Driven Pumps 1998-2014}

\section{INTRODUCTION}

This report presents an enhanced performance evaluation of turbine-driven pumps (TDPs) at U.S. commercial nuclear power plants from fiscal year (FY) - 1998 through FY - 2014. The objective of each updated component performance study is to obtain annual performance trends of failure rates and probabilities and to present an analysis of factors that could influence the component trends.

The data used in this study were based on the operating experience failure reports from the Institute of Nuclear Power Operations' (INPO) and Consolidated Events Database (ICES) Database [1]; formerly the Equipment Performance and Information Exchange Database (EPIX). Maintenance unavailability (UA) performance data comes from Mitigating Systems Performance Index (MSPI) data from 2002 through 2014 [1]. The TDP failure modes considered are for standby systems: failure to start (FTS), failure to run less than or equal to one hour $(\mathrm{FTR} \leq 1 \mathrm{H})$, failure to run greater than one hour $(\mathrm{FTR}>1 \mathrm{H})$, and for normally running systems: FTS and failure to run (FTR). TDP train maintenance unavailability data for trending are from the same time period, as reported in the Reactor Oversight Program and ICES. In addition to the presentation of the component failure mode data and the UA data, 8-hour unreliability is calculated and trended.

Each of the component reliability estimates and the reliability data are trended for the most recent 10year period, similar to the NRC's Industry Trend Program [2]. Additionally, yearly estimates for reliability are provided for the entire active period.

This study is modeled on the web page updates associated with the NUREG/CR-1715 series of reports [3], which was published around 2000. Those studies relied on operating experience obtained from licensee event reports, the Nuclear Plant Reliability Data System (NPRDS), and ICES. The ICES database, which includes the Mitigating Systems Performance Index (MSPI) as a subset, has matured to the point where component availability and reliability can be estimated with a higher degree of accuracy. In addition, the population of data in ICES has been growing and is much larger than the population used in the previous studies.

This report does not estimate values for use in probabilistic risk assessments (PRAs), but does evaluate component performance over time. The 2010 Component Reliability Update [4], is an update to the report: Industry-Average Performance for Components and Initiating Events at U.S Commercial Nuclear Power Plants [5] and reports the current TDP unreliability estimates for probabilistic risk assessments (PRA). Estimates from that report are included herein, for comparison. These estimates are labelled "2010 Update" in the associated tables and figures.

Previously, the study relied on operating experience obtained from licensee event reports, Nuclear Plant Reliability Data System, and ICES. The ICES database (which includes as a subset the MSPI designated devices) has matured to the point where component availability and reliability can be estimated with a higher degree of assurance of accuracy. In addition, the population of data is much larger than the population used in the previous study.

The objective of the effort for the updated component performance studies is to obtain annual performance trends of failure rates and probabilities. An overview of the trending methods, glossary of terms, and abbreviations can be found in the Overview and Reference document on the Reactor Operational Experience Results and Databases web page [6]. 
The objective of the enhanced component performance study is to present an analysis of factors that could influence the system and component trends in addition to annual performance trends of failure rates and probabilities. The factors analyzed for the TDP component are the differences in failures between total demands and actual unplanned [engineered safety feature (ESF)] demands (Section 6.3). Statistical analyses of the differences are performed and results showing whether pooling is acceptable across these factors are shown. In addition, engineering analyses were performed with respect to time period and failure mode (Section 6.4). The factors analyzed are sub-component, failure cause, recovery, and detection method. 


\section{SUMMARY OF FINDINGS}

The results of this study are summarized in this section. Of particular interest is the existence of any statistically significant ${ }^{\mathrm{a}}$ increasing trends. Figures 9 and 10 are providing essentially the same information since each start demand is assumed to result in the accumulation of one hour towards the exposure for FTR $\leq 1 \mathrm{H}$.

\subsection{Increasing Trends}

\subsubsection{Extremely Statistically Significant}

- None.

\subsubsection{Highly Statistically Significant}

- None.

\subsubsection{Statistically Significant}

- Originally a highly statistically significant increasing trend for TDP unavailability (Figure 6) was found using an iteratively re-weighted least squares routine which is currently built into the annual update software. When independently re-evaluated using a normal generalized linear regression the trend was not significant.

- A highly statistically significant increasing trend for start demands for standby TDPs (Figure 9).

- A highly statistically significant increasing trend for run hours for the first hour for standby TDPs (Figure 10).

\subsection{Decreasing Trends}

Both of the decreasing trends are only significant because of the consistent (lack of variation) values year-to-year. The actual decrease is less than $5 \%$ for both trends over the most recent 10 -year period.

\subsubsection{Extremely Statistically Significant}

- A highly statistically significant decreasing trend for run hours per reactor critical year for normally running TDPs (Figure 16).

\subsubsection{Highly Statistically Significant}

- A highly statistically significant decreasing trend for start demands for normally running TDPs (Figure 15) was identified using an iteratively re-weighted least squares routine. When independently re-evaluated using a normal generalized linear regression the trend was not significant.

\subsubsection{Statistically Significant}

- None

a. Statistically significant is defined in terms of the 'p-value.' A p-value is a probability indicating whether to accept or reject the null hypothesis that there is no trend in the data. P-values of less than or equal to 0.05 indicate that we are $95 \%$ confident that there is a trend in the data (reject the null hypothesis of no trend.) By convention, we use the "Michelin Guide" scale: p-value $<0.05$ (statistically significant), p-value $<0.01$ (highly statistically significant); p-value $<0.001$ (extremely statistically significant). 


\subsection{Consistency Check Results}

An ongoing concern in the industry is whether industry average failure estimates adequately predict standby component performance during unplanned (ESF) demands. Section 6.3 shows the results of the consistency check between industry-average failure rate count predictions and ESF detected failure observations. The consistency checks using unplanned demand data indicate that FTS and FTR $>1 \mathrm{H}$ failure observations are consistent with the industry-average failure predictions. The unplanned demand observation for the FTR $\leq 1 \mathrm{H}$ failure mode is not consistent and lies in the lower $95 \%$ meaning that the TDPs perform worse than predicted by the industry-average distribution for the FTR $\leq 1 \mathrm{H}$ failure mode. 


\section{FAILURE PROBABILITIES AND FAILURE RATES}

\subsection{Overview}

The industry-wide failure probabilities and failure rates of TDPs have been calculated from the operating experience for FTS, FTR $\leq 1 \mathrm{H}, \mathrm{FTR}>1 \mathrm{H}$, and FTR. The TDP data set obtained from ICES includes TDPs in the systems listed in Table 1. Table 2 shows industry-wide failure probability and failure rate results for the TDP [4].

Table 1. TDP systems.

\begin{tabular}{llcc}
\hline System & \multicolumn{1}{c}{ Description } & Standby & $\begin{array}{c}\text { Normally } \\
\text { Running }\end{array}$ \\
\hline AFW & Auxiliary feed water & 74 & \\
HPCI & High pressure coolant injection & 28 & \\
MFW & Main feed water & & 40 \\
RCIC & Reactor core isolation cooling & 31 & \\
& Total & 133 & 40 \\
\hline
\end{tabular}

The TDPs are assumed to operate both when the reactor is critical and during shutdown periods with sufficient steam pressure. The number of TDPs in operation is assumed to be constant throughout the study period. All demand types are considered - testing, non-testing, and, as applicable, ESF demands.

Table 2. Industry-wide distributions of $p$ (failure probability) and $\lambda$ (hourly rate) for TDPs.

\begin{tabular}{llccccccc}
\hline & Failure & & & & & \multicolumn{3}{c}{ Distribution } \\
\cline { 8 - 11 } Operation & Mode & $\mathbf{5 \%}$ & Median & Mean & $\mathbf{9 5 \%}$ & Type & $\boldsymbol{\alpha}$ & $\boldsymbol{\beta}$ \\
\hline Standby & FTS & $2.88 \mathrm{E}-04$ & $4.41 \mathrm{E}-03$ & $6.49 \mathrm{E}-03$ & $1.98 \mathrm{E}-02$ & Beta & 0.94 & $1.441 \mathrm{E}+02$ \\
& FTR $\leq 1 \mathrm{H}$ & $2.07 \mathrm{E}-04$ & $3.03 \mathrm{E}-03$ & $4.43 \mathrm{E}-03$ & $1.34 \mathrm{E}-02$ & Beta & 0.96 & $2.164 \mathrm{E}+02$ \\
& FTR>1H & $9.10 \mathrm{E}-04$ & $1.52 \mathrm{E}-03$ & $1.56 \mathrm{E}-03$ & $2.35 \mathrm{E}-03$ & Gamma & 12.50 & $8.028 \mathrm{E}+03$ \\
Running/ & FTS & $3.25 \mathrm{E}-04$ & $5.89 \mathrm{E}-03$ & $8.93 \mathrm{E}-03$ & $2.79 \mathrm{E}-02$ & Beta & 0.88 & $9.728 \mathrm{E}+01$ \\
Alternating & FTR & $1.44 \mathrm{E}-06$ & $7.67 \mathrm{E}-06$ & $9.34 \mathrm{E}-06$ & $2.29 \mathrm{E}-05$ & Gamma & 1.79 & $1.919 \mathrm{E}+05$ \\
\hline
\end{tabular}




\subsection{TDP Failure Probability and Failure Rate Trends}

The trends are shown for industry standby and for industry normally running results. Trends in the standby TDP failure probabilities and failure rates are shown in Figure 1 to Figure 3. The data for the trend plots are contained in Table 9 to Table 11. The standby systems from Table 1 are trended together for each failure mode. Trends in the failure probabilities and failure rates for normally operating TDPs are shown in Figure 4 and Figure 5. The data for the trend plots are contained in Table 12 and Table 13.

In the plots, the means of the posterior distributions from the Bayesian update process were trended across the years. The posterior distributions were also used for the vertical bounds for each year. The 5 th and 95th percentiles of these distributions give an indication of the relative variation from year to year in the data. When there are no failures, the interval tends to be larger than the interval for years when there are one or more failures. The larger interval reflects the uncertainty that comes from having little information in that year's data. Such uncertainty intervals are determined by the prior distribution. In each plot, a relatively "flat" constrained non-informative prior distribution (CNID) is used, which has large bounds.

The horizontal curves plotted around the regression lines in the graphs show 90 percent simultaneous confidence bands for the fitted lines. The simultaneous confidence band bounds are larger than ordinary confidence intervals for the trended values because they form a band that has a $90 \%$ probability of containing the entire line. In the lower left hand corner of the trend figures, the regression $p$-values are reported. They come from a statistical test on whether the slope of the regression line might be zero. Low p-values indicate that the slopes are not likely to be zero, and that trends exist.

The regression methods are all based on "ordinary least squares" (OLS); which minimizes the square of the vertical distance between the annual data points and the regression line. The p-values assume normal distributions for the data in each year, with a constant variance across the years. In the case where the data involve failure counts, the method of iterative reweighing accounts for the fact that count data are not expected to have a constant variance (for example, the variance for Poisson-distributed counts is equal to the expected number of counts). Further information on the trending methods is provided in Section 2 of the Overview and Reference document [6].

"Generalized linear model" (GLM) regression is a trending method that accounts for the expected variance of the count data. The method is based on maximizing the likelihood of the observed data. It uses the actual data - counts and demands or time; no transformation of the input data are needed. It can also be applied to ordinary data that might be normally-distributed, in which case it gives the same result if the sample is large enough. In this study, the GLM method was applied using the R [7] and SAS [8] statistical packages for those cases where the p-value was less than or equal to 0.10 . Instances have occurred where the p-value from OLS is less than 0.05 but the GLM p-value exceeds 0.05 . In these instances, the GLM method is believed to be more reliable because it accounts for more of the features present in the data.

Further information on the trending methods is provided in Section 2 of the Overview and Reference document [6]. A final feature of the trend graphs is that the baseline industry values from Table 2 are shown for comparison. 


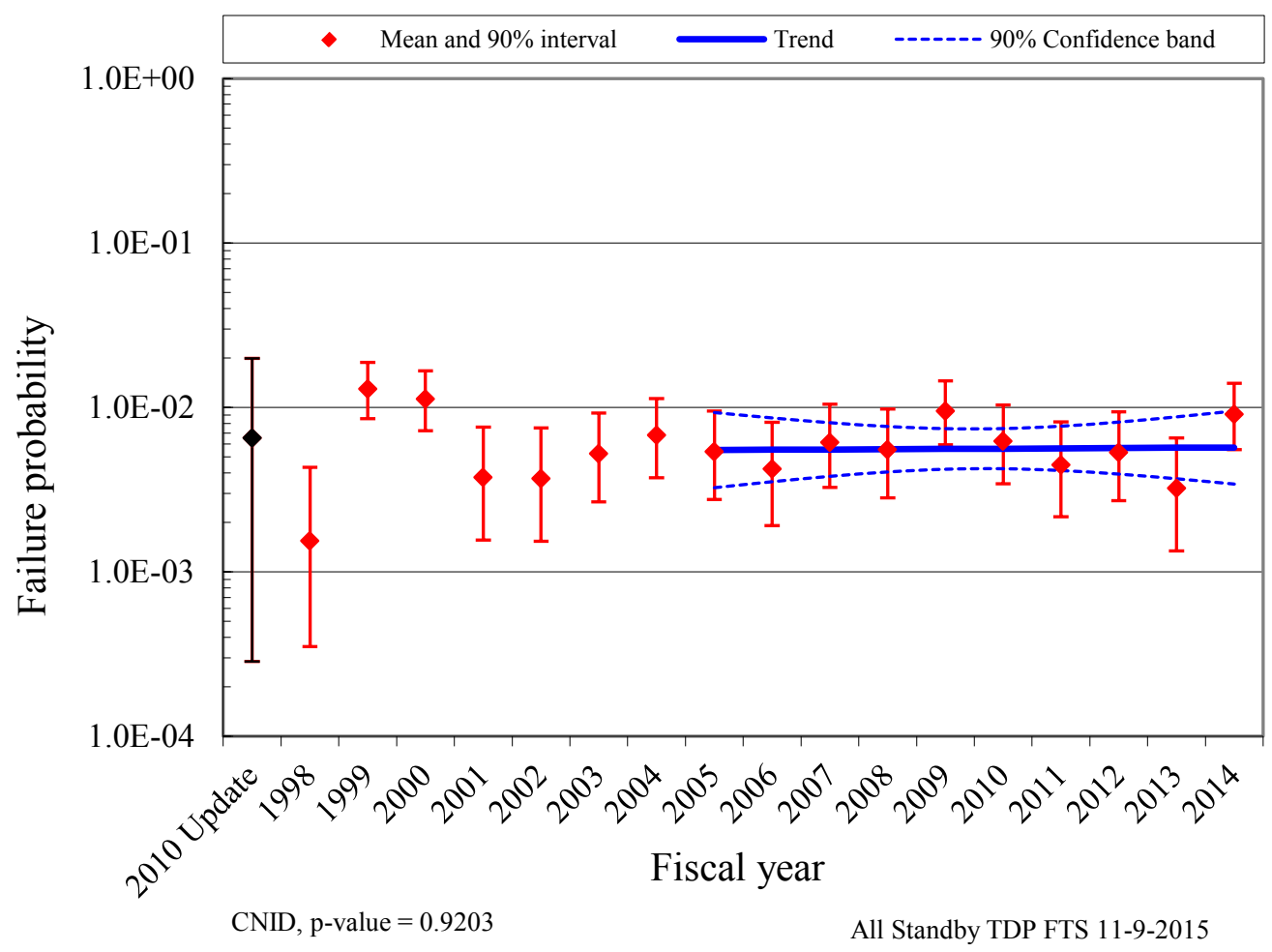

Figure 1. Failure probability estimate trend for standby systems, industry-wide TDP FTS trend.

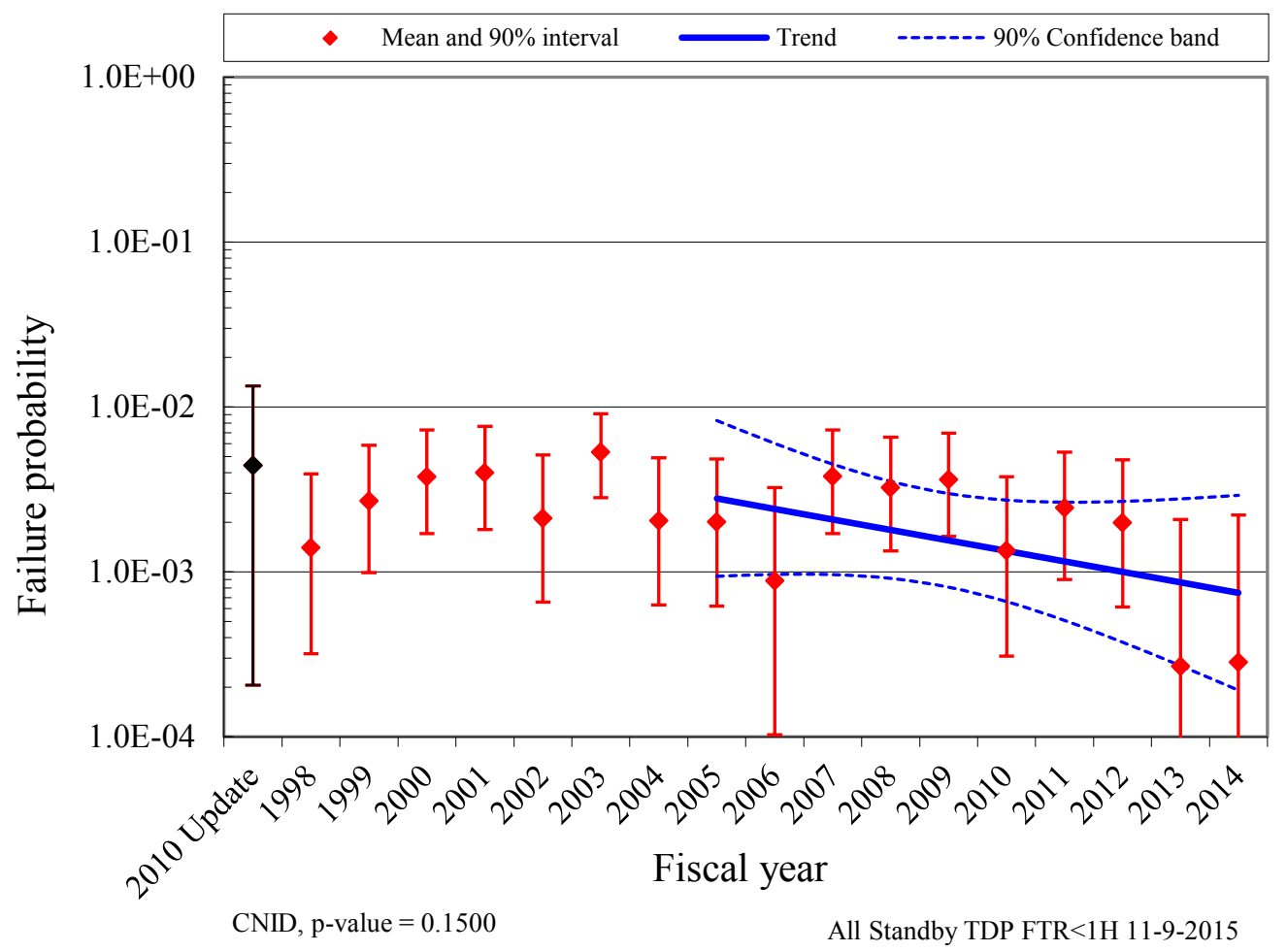

Figure 2. Failure probability estimate trend for standby systems, industry-wide TDP FTR $\leq 1 H$ trend. 


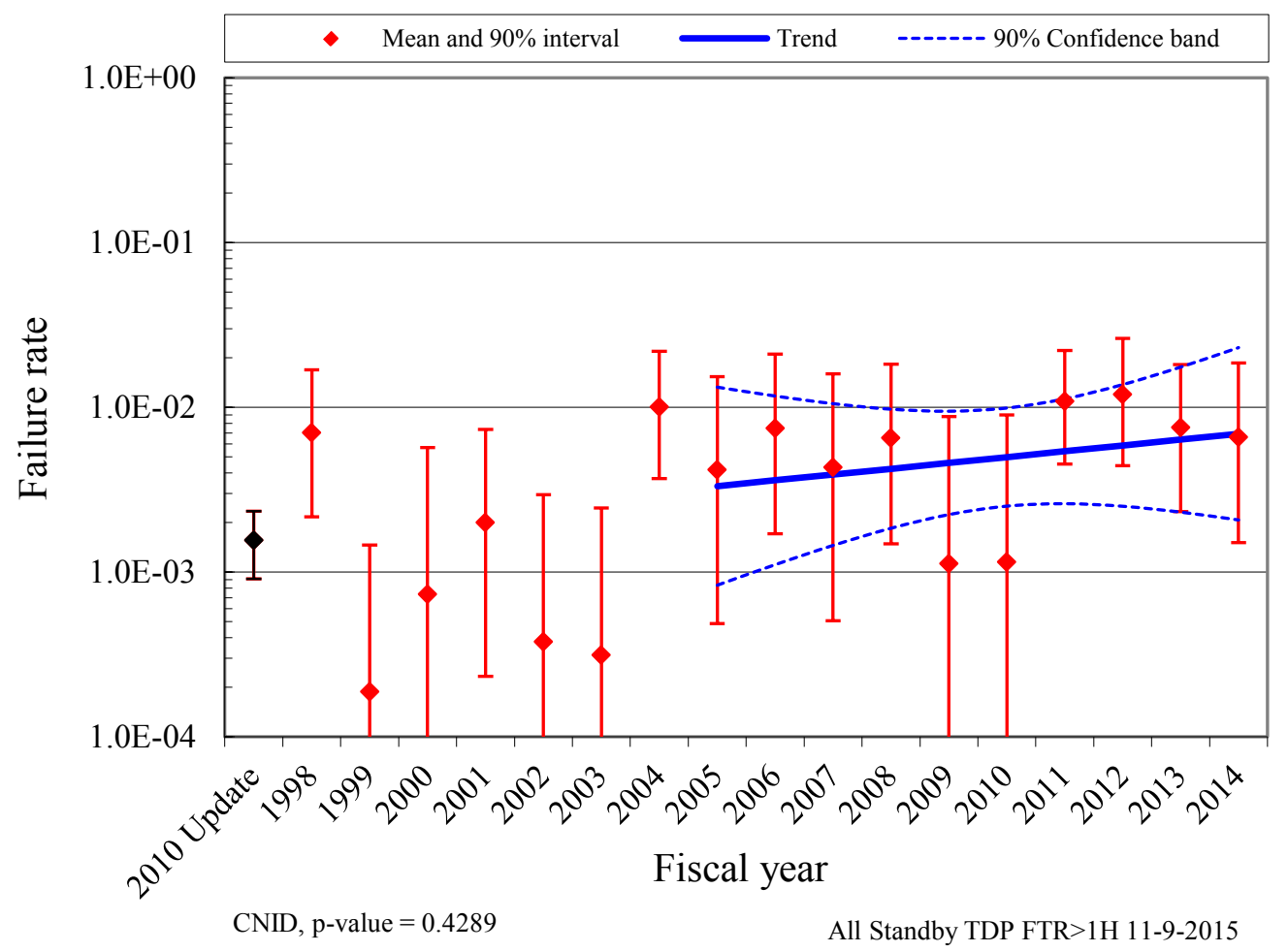

Figure 3. Failure rate estimate trend for standby systems, industry-wide TDP FTR $>1 \mathrm{H}$ trend.

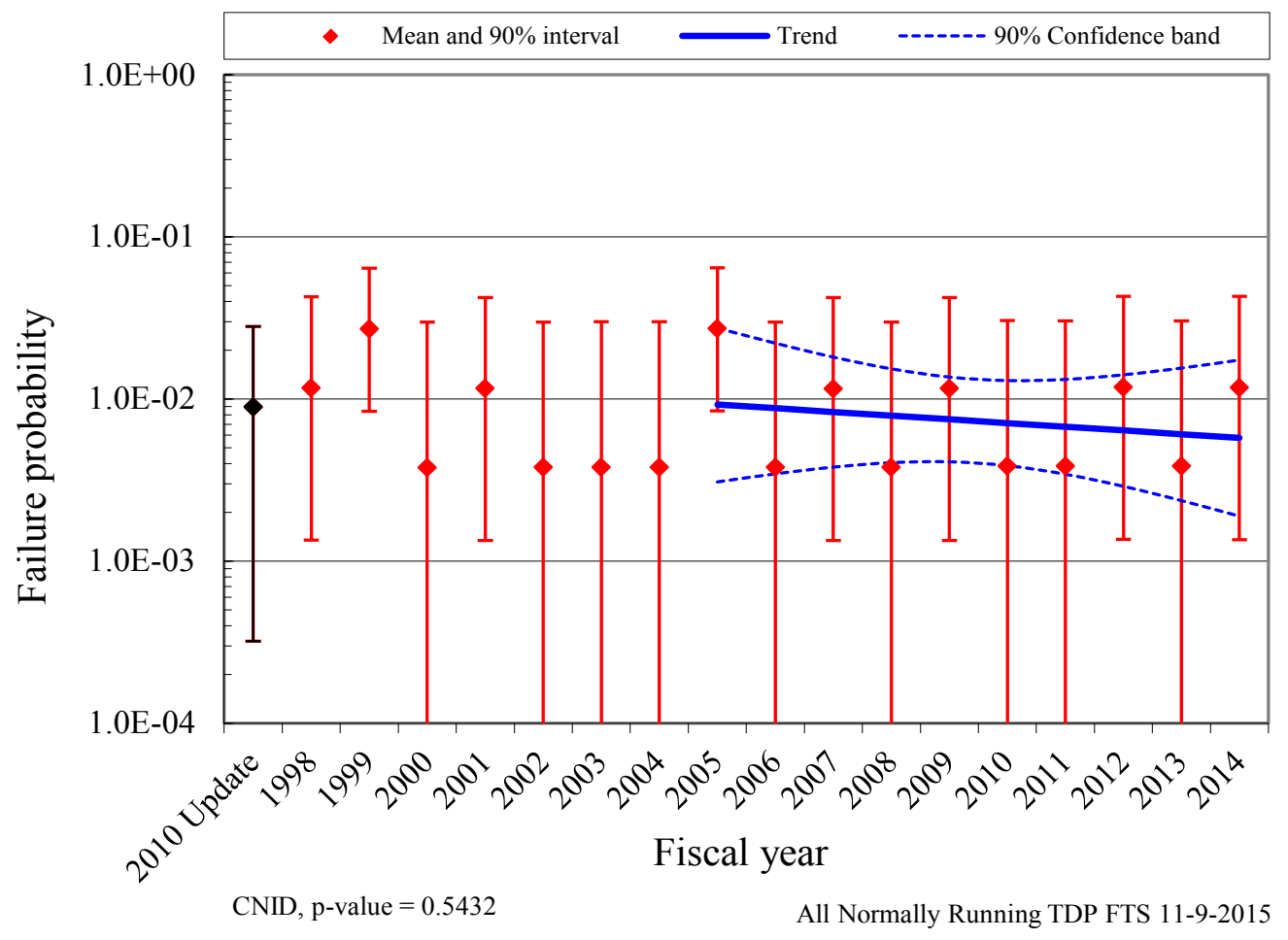

Figure 4. Failure probability estimate trend for normally running systems (MFW), industry-wide TDP FTS trend. 


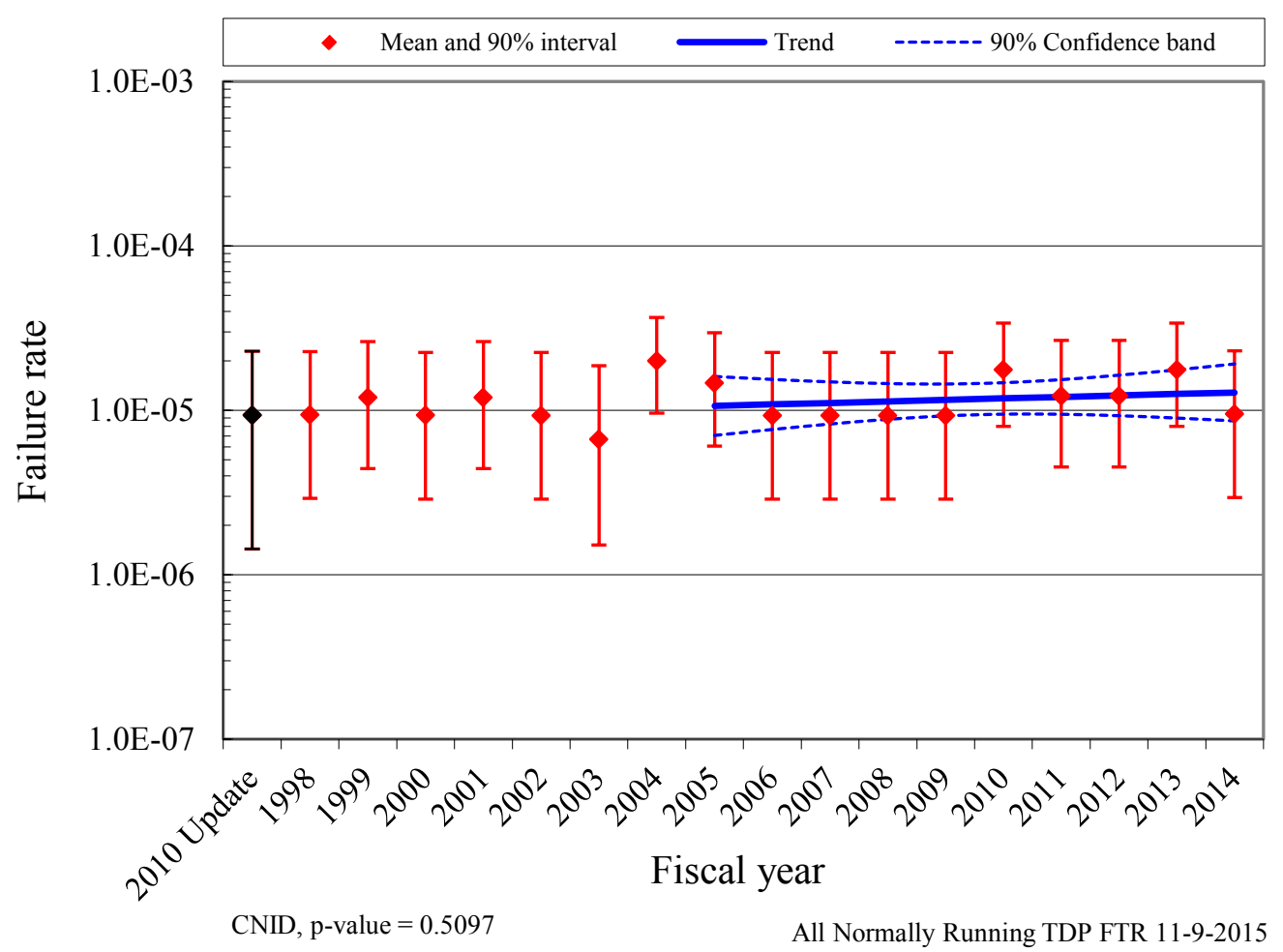

Figure 5. Failure rate estimate trend for normally running systems (MFW), industry-wide TDP FTR trend. 
Enhanced Component Performance Study 


\section{UNAVAILABILITY}

\subsection{Overview}

The industry-wide test or maintenance UA of TDP trains has been calculated from the operating experience. UA data are for TDP trains, which can include more than just the TDP. However, in most cases the TDP contributes the majority of the UA reported. Table 3 shows overall results for the TDP [4] based on UA data from MSPI Basis Documents, covering 2002 to 2010. In the calculations, planned and unplanned unavailable hours for a train are combined.

Table 3. Industry-average distributions of unavailability for TDPs.

\begin{tabular}{lccrr}
\multicolumn{1}{c}{ Description } & Mean & Distribution & \multicolumn{1}{c}{$\boldsymbol{\alpha}$} & \multicolumn{1}{c}{$\boldsymbol{\beta}$} \\
\hline TDP test or maintenance (AFW) & $5.33 \mathrm{E}-03$ & Beta & 1.93 & 360.48 \\
\hline TDP test or maintenance (ALL) & $7.76 \mathrm{E}-03$ & Beta & 2.17 & 277.36 \\
TDP test or maintenance (HPCI) & $1.15 \mathrm{E}-02$ & Beta & 11.88 & 1024.52 \\
TDP test or maintenance (RCIC) & $1.02 \mathrm{E}-02$ & Beta & 5.65 & 550.06 \\
\hline
\end{tabular}

\subsection{TDP Unavailability Trends}

For the FY 1998-2014 period, the following are overall maintenance unavailability data. Note that these data do not supersede the data in Table 3 for use in risk assessments.

The trend in standby TDP train unavailability is shown in Figure 6. The data for this figure is in Table 14. The TDPs in systems AFW, HPCI, and RCIC are pooled and trended (these are the systems with maintenance unavailability data currently analyzed). The trend chart shows the results of using data for each year's component unavailability data over time. The yearly (FY 1998-2014) unavailability and reactor critical hour data were obtained from the Reactor Oversight Program (1998 to 2001) and ICES (FY 2002 to 2014) data for the TDP component. The total downtimes during operation for each plant and year were summed, and divided by the corresponding number of TDP-reactor critical hours.

Unavailability data for shutdown periods are not reported.

The mean and variance for each year is the sample mean and variance calculated from the plant-level unavailability's for that year. The vertical bar spans the calculated 5th to 95th percentiles of the beta distribution with matching means.

For the trend graphs, a least squares fit is sought for the linear or logit model. Section 3 in the Overview and Reference document provides further information [6]. In the lower left hand corner of the trend figures, the p-value is reported. 


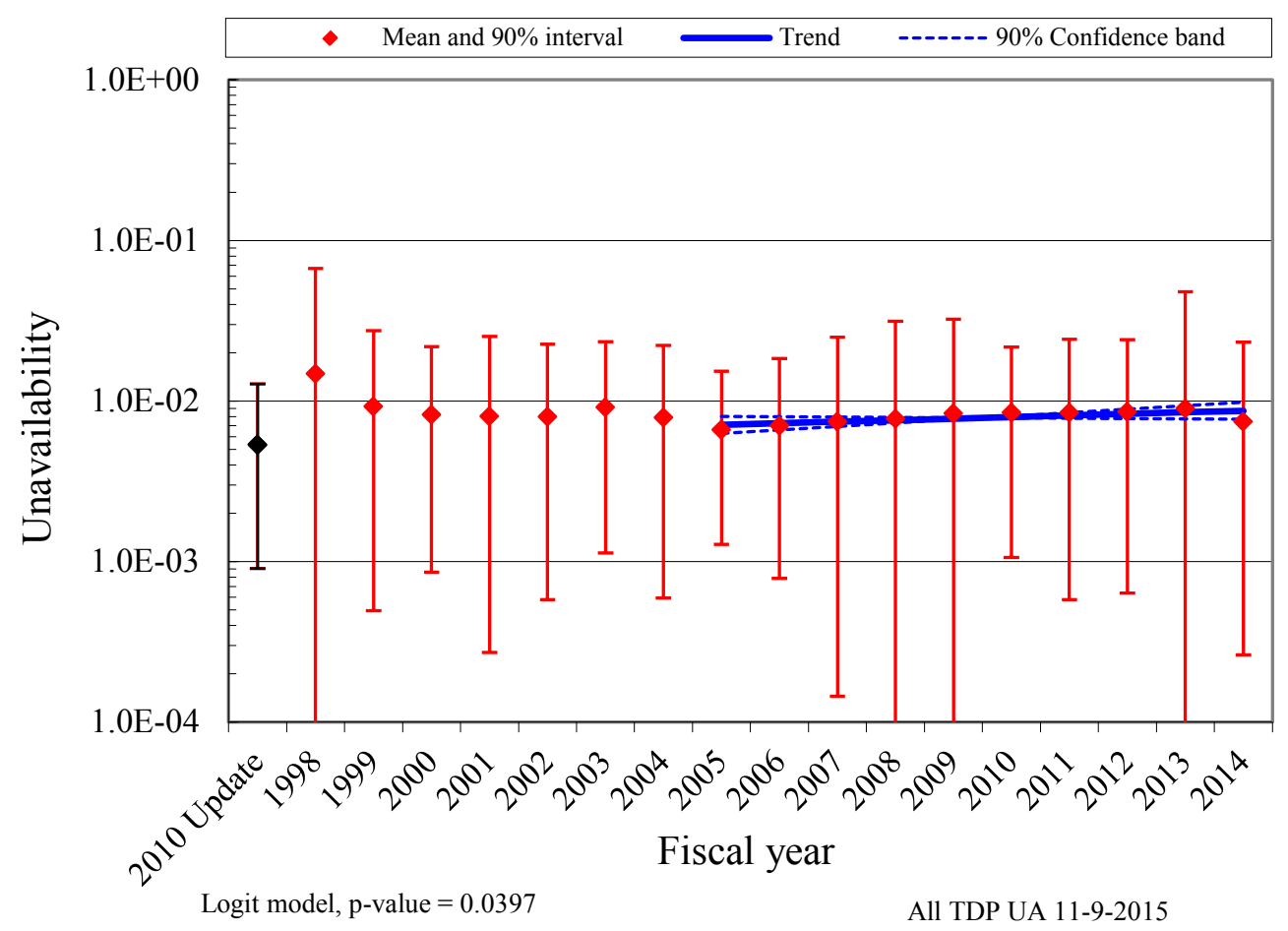

Figure 6. Pooled AFW, HPCI, and RCIC TDP UA trend. 


\section{TDP UNRELIABILITY TRENDS}

Trends in total component unreliability are shown in Figure 7 and Figure 8. Plot data for these figures are in Table 15 and Table 16, respectively. Total unreliability is defined as the result of the union of the UA, FTS, FTR $\leq 1 \mathrm{H}$, and FTR $>1 \mathrm{H}$ (or FTR) failure probabilities. The FTR $>1 \mathrm{H}$ is calculated for 7 hours and the FTR is calculated for 8 hours to provide the results for an 8 -hour mission. Since the normally running systems TDP components do not have UA data or the FTR $\leq 1 \mathrm{H}$ data, there is no UA or $\mathrm{FTR} \leq 1 \mathrm{H}$ for that calculation. The trending method is described in more detail in Section 4 of the Overview and Reference document [6]. In the lower left hand corner of the trend figures, the regression method is reported.

No "2010 Update" data for use in risk assessments are cited for EDG unreliability because these data are not published. The risk assessment models compute unreliability as an output rather than an input. Additionally the standby systems from Table 2 are trended together.

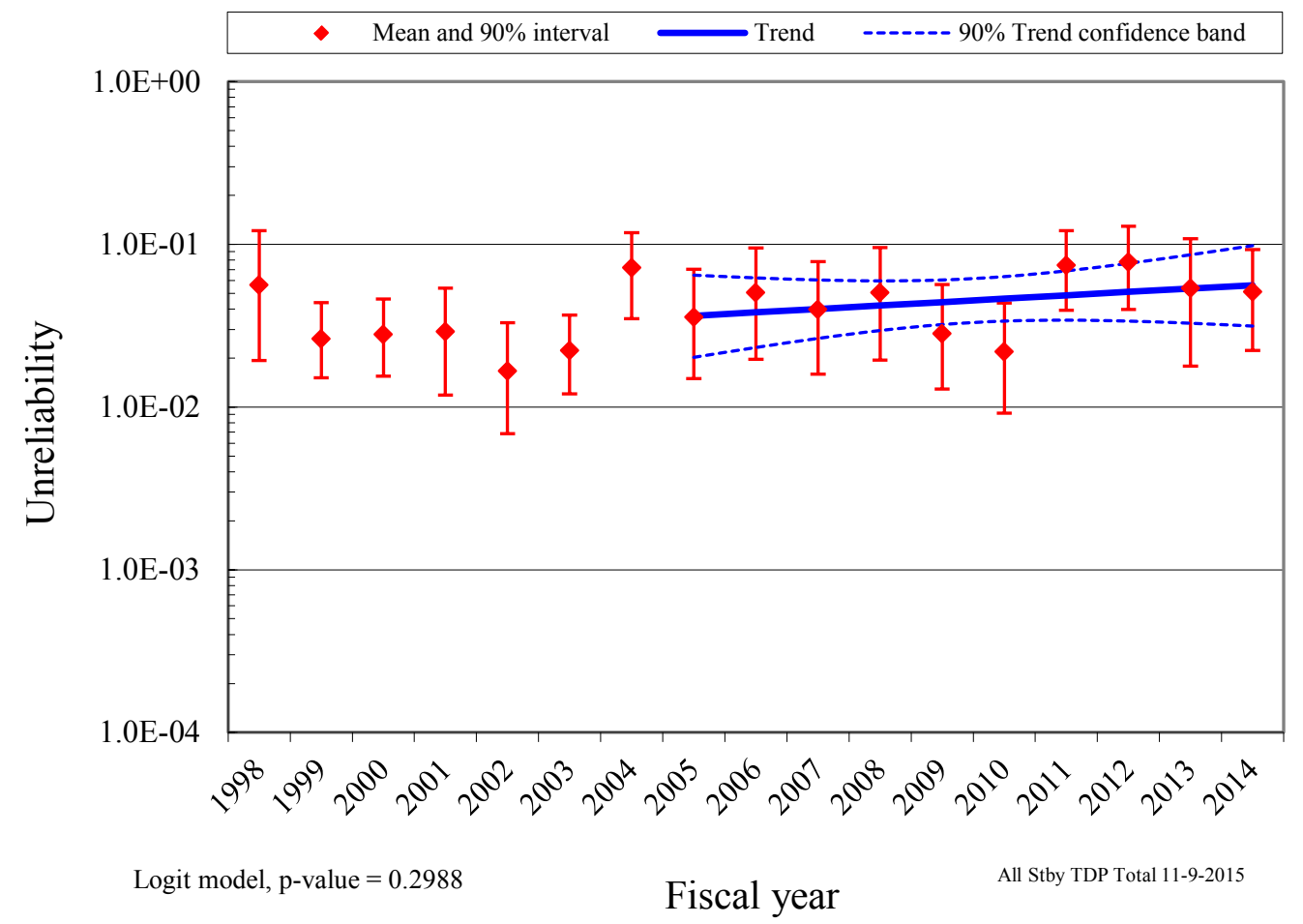

Figure 7. Standby systems, industry-wide TDP unreliability trend (8-hour mission). 


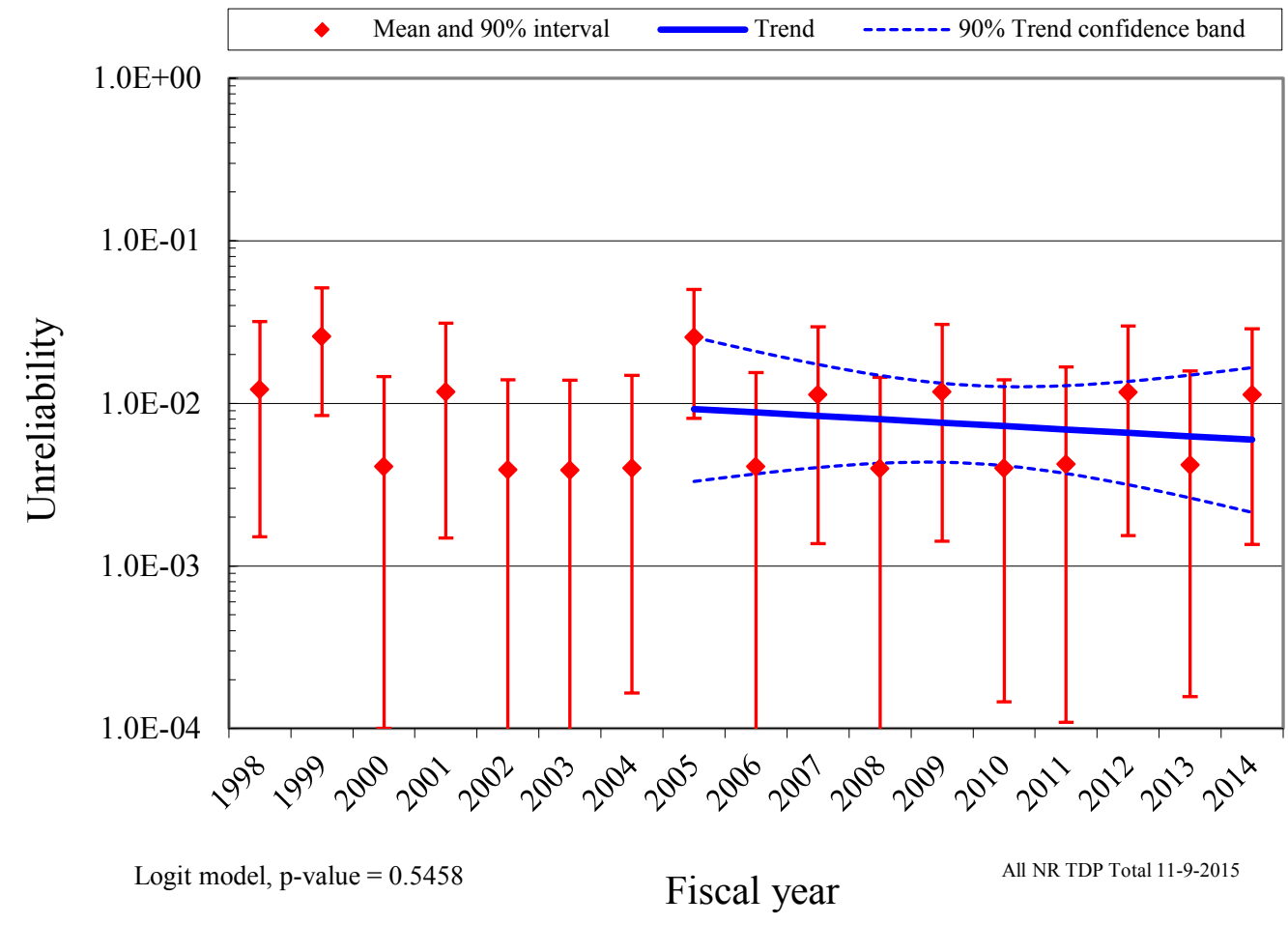

Figure 8. Normally running systems, industry-wide TDP unreliability trend (8-hour mission). 


\section{ENGINEERING TRENDS}

This section presents frequency trends for TDP failures and demands. The data are normalized by reactor year for plants that have the equipment being trended. The rate methods described in Section 2 of the Overview and Reference document are used [6].

\subsection{Standby TDP Engineering Trends}

Figure 9 shows the trend for standby TDP start demands. Figure 10 shows the trend for TDP run $\leq 1$ hour demands. Figure 11 shows the trend for the TDP run hours. Table 17, Table 18, and Table 19 provide the plot data, respectively.

Figure 12 shows the trend for TDP FTS events. Figure 13 shows the trend for TDP FTR $\leq 1 \mathrm{H}$ events, and Figure 14 shows the trend for the TDP FTR $>1 \mathrm{H}$ events. Table 20, Table 22, and Table 23 provide the plot data, respectively. The standby systems from Table 2 are trended together for each figure.

Table 4 summarizes the failures by system and year for the FTS failure mode. Table 5 summarizes the failures by system and year for the FTR $\leq 1 \mathrm{H}$ failure mode. Table 6 summarizes the failures by system and year for the FTR $>1 \mathrm{H}$ failure mode. Table 4, Table 5, and Table 6 only include systems where failures of that failure mode have been detected.

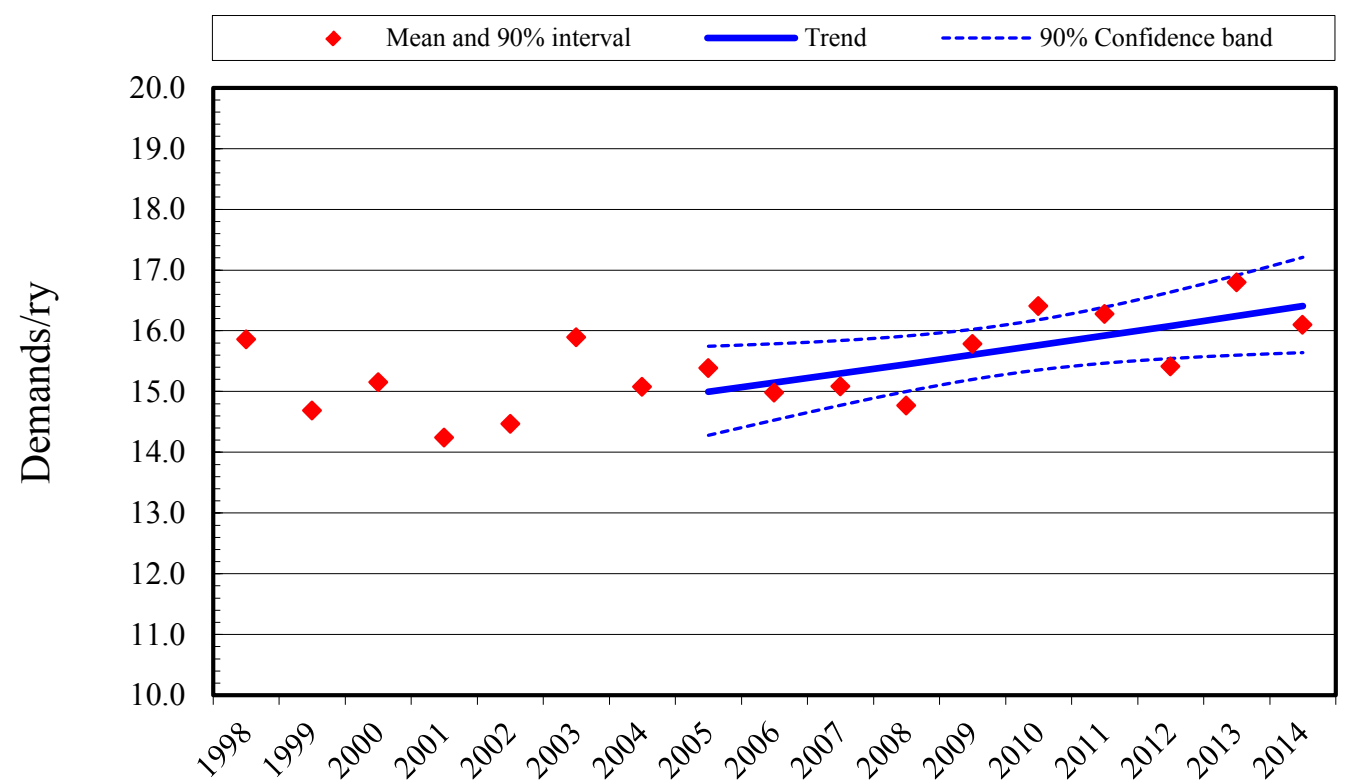

Fiscal year

CNID, p-value $=0.0250$

Figure 9. Frequency (events per reactor year) of start demands, standby TDPs. 


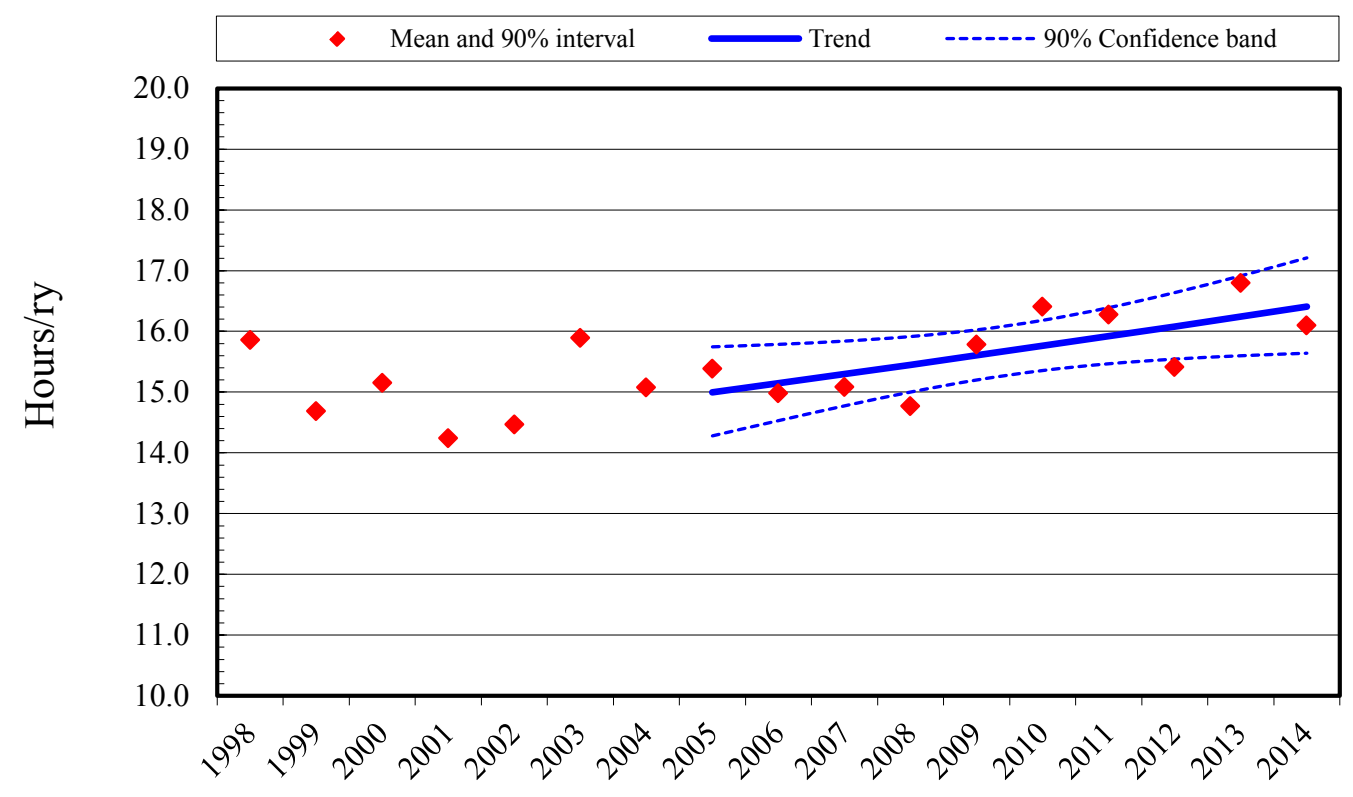

Fiscal year

CNID, $\mathrm{p}$-value $=0.0250 \quad$ All Standby TDP FTR $<1$ H 11-9-2015

Figure 10. Standby TDP run hours per reactor critical year of run $\leq 1$ H hours.

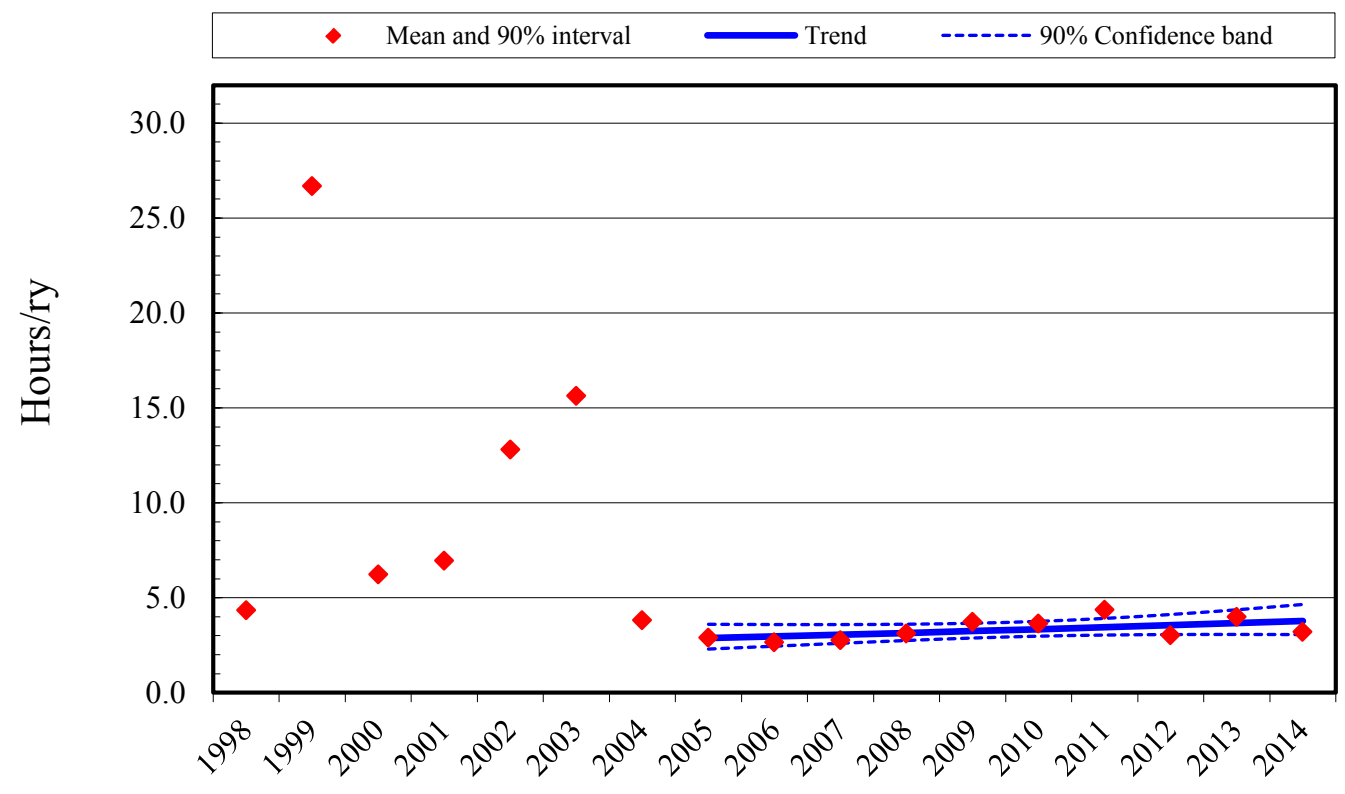

Fiscal year

CNID, $\mathrm{p}$-value $=0.1025$

All Standby TDP FTR >1H 11-9-2015

Figure 11. Standby TDP run hours per reactor critical year. 


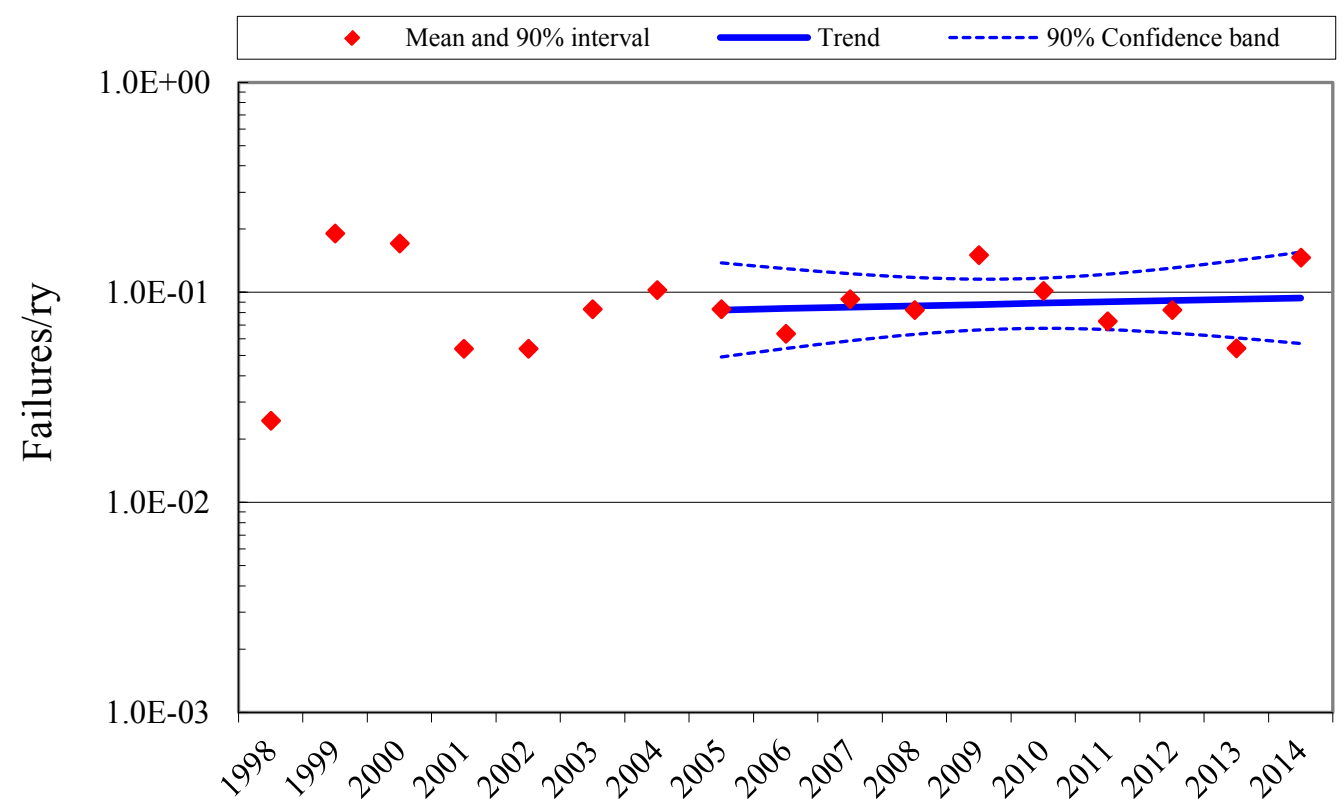

Fiscal year

CNID, p-value $=0.7106$

All Standby TDP FTS 11-9-2015

Figure 12. Frequency (events per reactor year) of FTS events, standby TDPs.

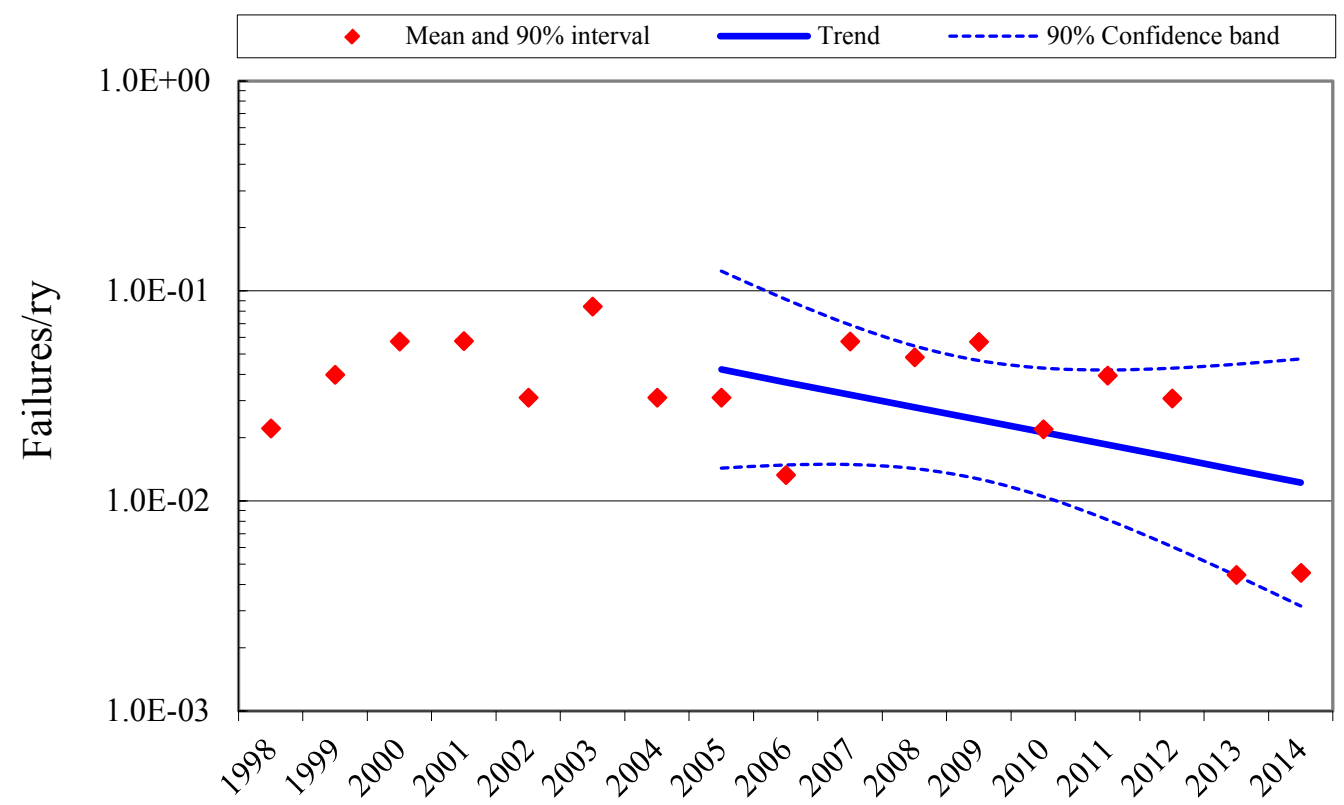

Fiscal year

CNID, $\mathrm{p}$-value $=0.1712$

All Standby TDP FTR $<1$ H 11-9-2015

Figure 13. Frequency (events per reactor year) of FTR $\leq 1 \mathrm{H}$ events, standby TDPs. 


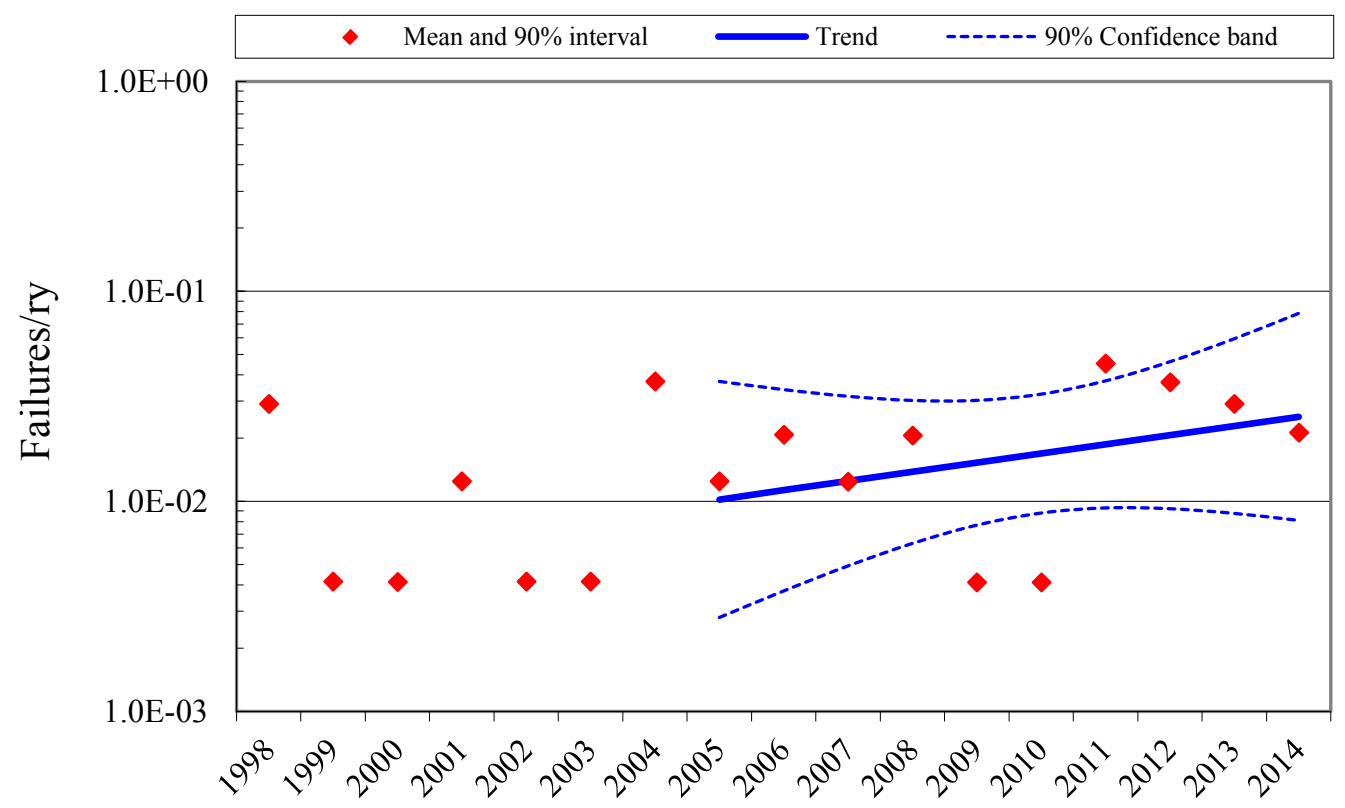

Fiscal year

CNID, p-value $=0.3020$

All Standby TDP FTR $>1 \mathrm{H}$ 11-9-2015

Figure 14. Frequency (events per reactor year) of FTR $>1$ H events, standby TDPs.

\subsection{Normally Running TDP Engineering Trends}

Figure 15 shows the trend for TDP start demands and Figure 16 shows the trend for the TDP run hours. Table 23 and Table 24 provide the plot data, respectively.

Figure 17 shows the trend for TDP FTS events and Figure 18 shows the trend for the TDP FTR events. Table 25 and Table 26 provide the plot data, respectively. The normally running system (MFW) from Table 2 is trended for each figure. 


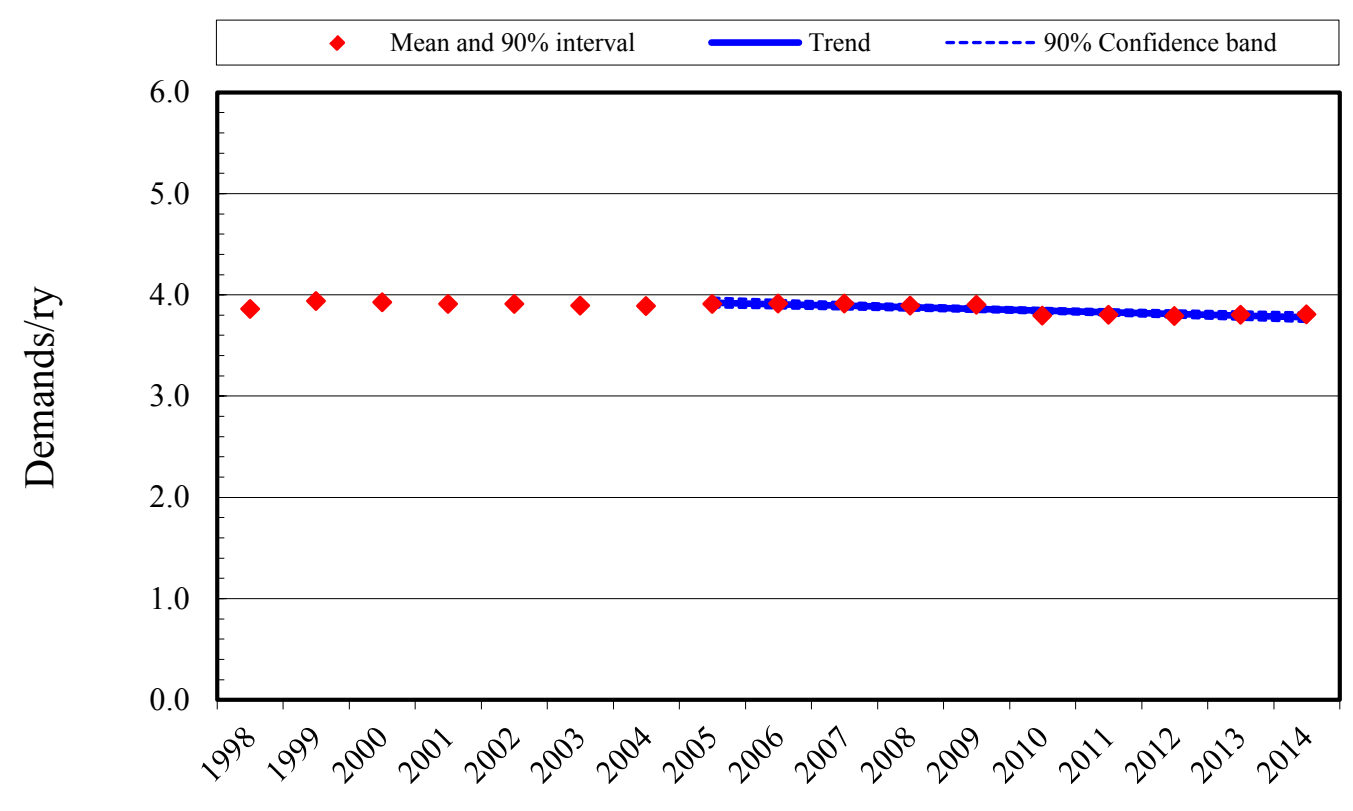

Fiscal year

CNID, p-value $=0.0011 \quad$ All Normally Running TDP FTS 11-9-2015

Figure 15. Frequency (events per reactor year) of start demands, normally running TDPs.

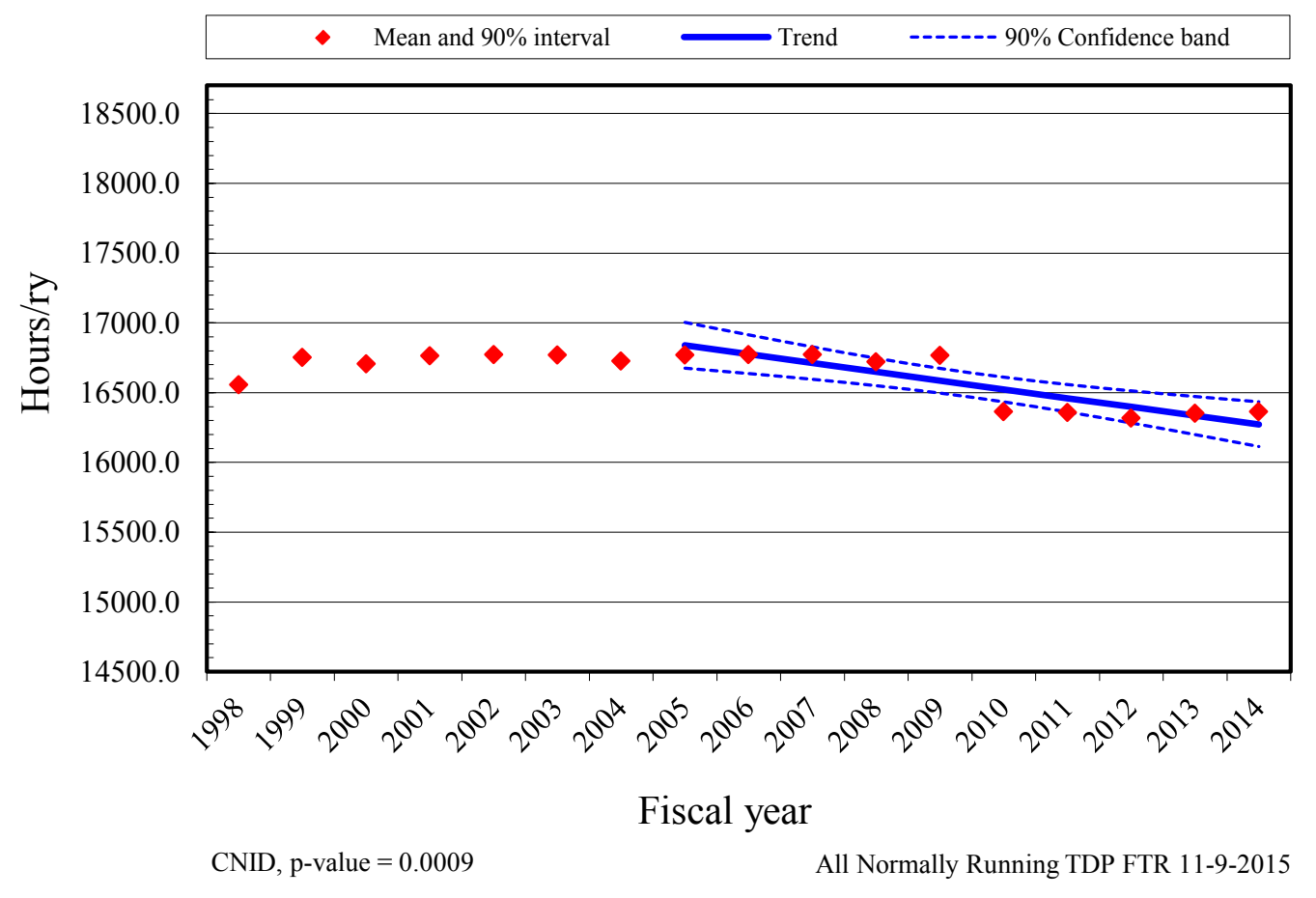

Figure 16. Normally running TDP run hours per reactor year. 


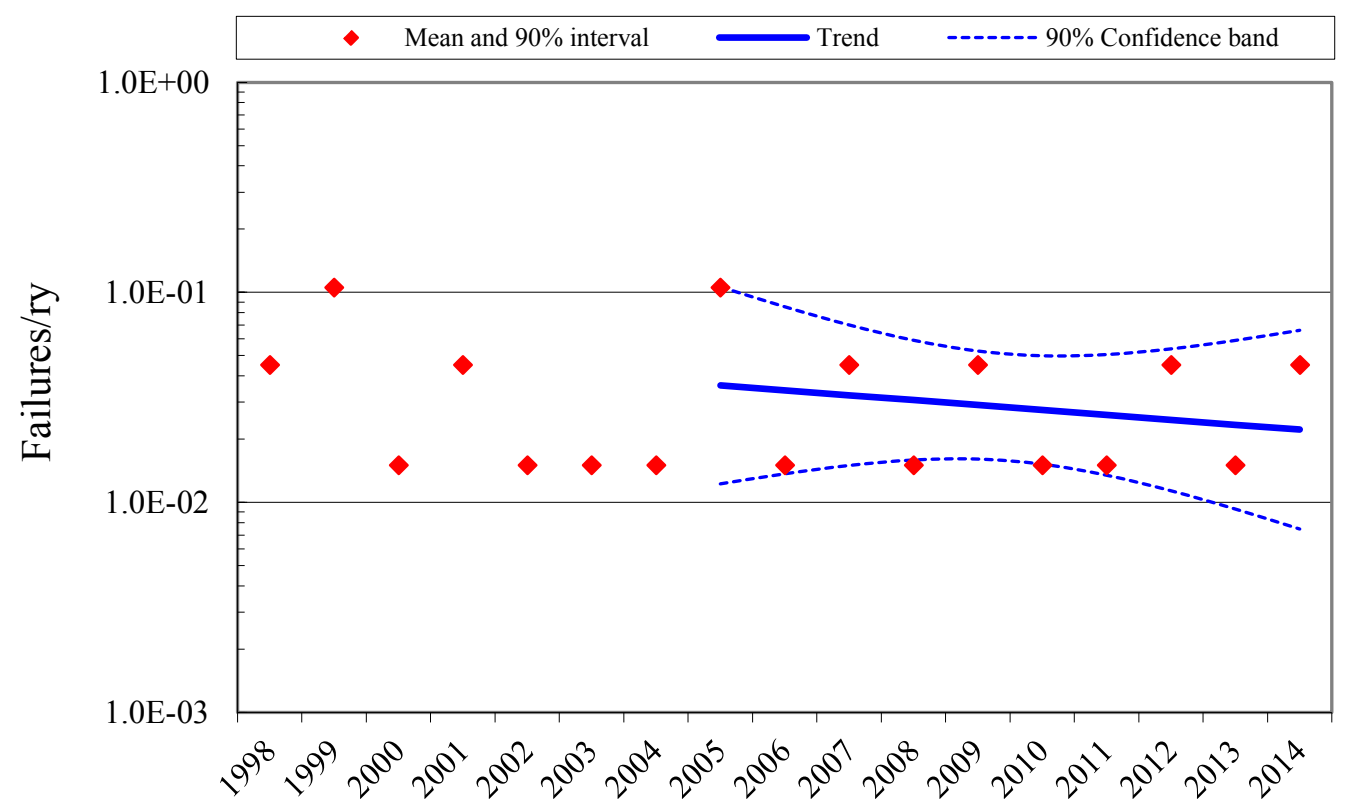

Fiscal year

CNID, p-value $=0.5258$

All Normally Running TDP FTS 11-9-2015

Figure 17. Frequency (events per reactor year) of FTS events, normally running TDPS.

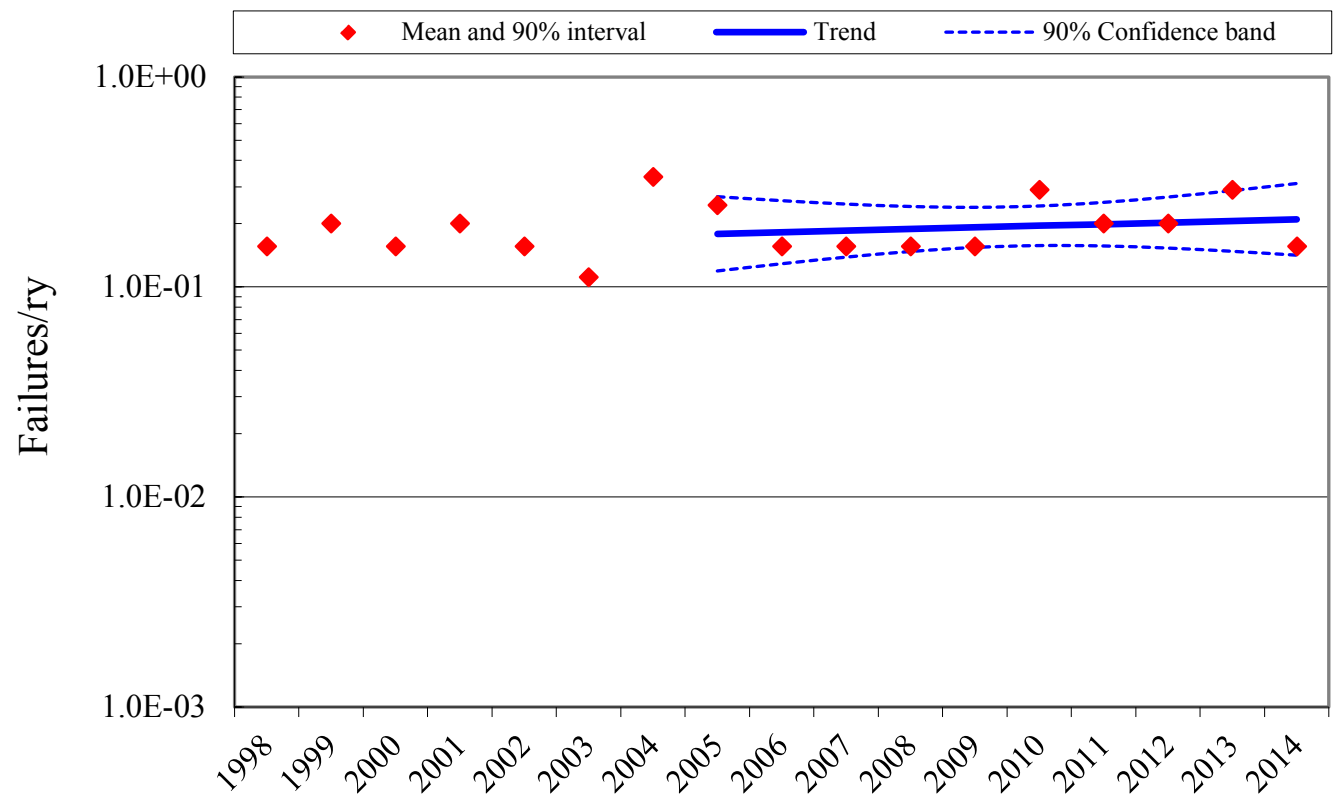

Fiscal year

CNID, $\mathrm{p}$-value $=0.5732$

All Normally Running TDP FTR 11-9-2015

Figure 18. Frequency (events per reactor year) of FTR events, normally running TDPs. 
Table 4. Summary of TDP failure counts for the FTS failure mode over time by system.

\begin{tabular}{|c|c|c|c|c|c|c|c|c|c|c|c|c|c|c|}
\hline \multirow[b]{2}{*}{$\begin{array}{c}\text { System } \\
\text { Code }\end{array}$} & \multirow[b]{2}{*}{$\begin{array}{l}\text { TDP } \\
\text { Count }\end{array}$} & \multirow[b]{2}{*}{$\begin{array}{c}\text { TDP } \\
\text { Percent }\end{array}$} & \multicolumn{10}{|c|}{ Fiscal Year } & \multirow[b]{2}{*}{ Total } & \multirow{2}{*}{$\begin{array}{c}\text { Percent } \\
\text { of } \\
\text { Failures }\end{array}$} \\
\hline & & & 05 & 06 & 07 & 08 & 09 & 10 & 11 & 12 & 13 & 14 & & \\
\hline AFW & 74 & $42.5 \%$ & 4 & 3 & 4 & 3 & 10 & 4 & 4 & 2 & 1 & 12 & 47 & $48.5 \%$ \\
\hline $\mathrm{HCl}$ & 28 & $16.1 \%$ & 2 & 1 & 3 & 1 & 3 & 3 & 2 & 3 & 3 & 1 & 22 & $22.7 \%$ \\
\hline $\mathrm{RCl}$ & 31 & $17.8 \%$ & 2 & 2 & 2 & 4 & 2 & 3 & 1 & 3 & 1 & 1 & 21 & $21.6 \%$ \\
\hline MFW & 41 & $23.6 \%$ & 3 & 0 & 1 & 0 & 1 & 0 & 0 & 1 & 0 & 1 & 7 & $7.2 \%$ \\
\hline Total & 174 & $100.0 \%$ & 11 & 6 & 10 & 8 & 16 & 10 & 7 & 9 & 5 & 15 & 97 & $100.0 \%$ \\
\hline
\end{tabular}

Table 5. Summary of TDP failure counts for the FTR $\leq 1 \mathrm{H}$ failure mode over time by system.

\begin{tabular}{|c|c|c|c|c|c|c|c|c|c|c|c|c|c|c|}
\hline \multirow{2}{*}{$\begin{array}{c}\text { System } \\
\text { Code }\end{array}$} & \multirow{2}{*}{$\begin{array}{l}\text { TDP } \\
\text { Count }\end{array}$} & \multirow{2}{*}{$\begin{array}{c}\text { TDP } \\
\text { Percent }\end{array}$} & \multicolumn{10}{|c|}{ Fiscal Year } & \multirow[b]{2}{*}{ Total } & \multirow{2}{*}{$\begin{array}{c}\text { Percent of } \\
\text { Failures }\end{array}$} \\
\hline & & & 05 & 06 & 07 & 08 & 09 & 10 & 11 & 12 & 13 & 14 & & \\
\hline AFW & 74 & $55.6 \%$ & 1 & 1 & 2 & 3 & 4 & 2 & 1 & 2 & 0 & 0 & 16 & AFW \\
\hline $\mathrm{HCl}$ & 28 & $21.1 \%$ & 0 & 0 & 2 & 2 & 1 & 0 & 0 & 0 & 0 & 0 & 5 & $\mathrm{HCl}$ \\
\hline $\mathrm{RCl}$ & 31 & $23.3 \%$ & 2 & 0 & 2 & 0 & 1 & 0 & 3 & 1 & 0 & 0 & 9 & $\mathrm{RCl}$ \\
\hline Total & 133 & $100.0 \%$ & 3 & 1 & 6 & 5 & 6 & 2 & 4 & 3 & 0 & 0 & 30 & Total \\
\hline
\end{tabular}

Table 6. Summary of TDP failure counts for the FTR $>1 H$ and FTR failure mode over time by system.

\begin{tabular}{|c|c|c|c|c|c|c|c|c|c|c|c|c|c|c|}
\hline \multirow{2}{*}{$\begin{array}{c}\text { System } \\
\text { Code }\end{array}$} & \multirow{2}{*}{$\begin{array}{l}\text { TDP } \\
\text { Count }\end{array}$} & \multirow{2}{*}{$\begin{array}{c}\text { TDP } \\
\text { Percent }\end{array}$} & \multicolumn{10}{|c|}{ Fiscal Year } & \multirow[b]{2}{*}{ Total } & \multirow{2}{*}{$\begin{array}{c}\text { Percent of } \\
\text { Failures }\end{array}$} \\
\hline & & & 05 & 06 & 07 & 08 & 09 & 10 & 11 & 12 & 13 & 14 & & \\
\hline AFW & 74 & $42.5 \%$ & 1 & 2 & 0 & 1 & 0 & 0 & 2 & 3 & 1 & 2 & 11 & AFW \\
\hline $\mathrm{HCl}$ & 28 & $16.1 \%$ & 0 & 0 & 0 & 1 & 0 & 0 & 3 & 0 & 1 & 0 & 5 & $\mathrm{HCl}$ \\
\hline $\mathrm{RCl}$ & 31 & $17.8 \%$ & 0 & 0 & 1 & 0 & 0 & 0 & 0 & 1 & 1 & 0 & 3 & $\mathrm{RCl}$ \\
\hline MFW & 41 & $23.6 \%$ & 5 & 3 & 3 & 3 & 3 & 6 & 4 & 4 & 6 & 3 & 35 & MFW \\
\hline Total & 174 & $100.0 \%$ & 6 & 5 & 4 & 5 & 3 & 6 & 9 & 8 & 9 & 5 & 54 & Total \\
\hline
\end{tabular}




\subsection{Comparison of ICES TDP Unplanned Demand Results with Industry Results}

An ongoing concern in the industry is whether a combination of test, non-test demand, and actual demand data adequately represents standby component performance during unplanned demands. This comparison evaluates the same dataset for standby components that is used for the overall trends shown in this document, but limits the failure data to those that are discovered during an ESF demand and the ESF demands reported in ICES. The data are further limited to FY-2003 to present since the ESF demand reporting in ICES is inconsistent prior to FY-2003.

The standby TDP ESF unplanned demand data covering FY-2003 through FY-2013 are summarized in Table 7. Consistency between the unplanned demand data and industry-average performance from Table 2 was evaluated using the predictive distribution approach outlined in the Handbook of Parameter Estimation for PRA, NUREG/CR-6823, Sections 6.2.3.5 and 6.3.3.4 [9].

The unplanned demand data were aggregated at the plant and system level (failures and demands). Assuming each plant and system can have a different failure probability, the industry-average distribution (from Table 2) was sampled for each plant and system. The predicted number of failure events for each plant and system was evaluated using the binomial distribution with the plant-specific failure probability and its associated number of demands. Then the total number of predicted failures was obtained by summing the individual plant results. This process was repeated 1000 times, each time obtaining a total number of predicted failures. The 1000 sample results were ordered from high to low. Then the actual number of unplanned demand failures observed (listed in Table 7) was compared with this ordered sample to determine the probability of observing this number of failures or greater. If the probability was greater than 0.05 and less than 0.95 , then the unplanned demand performance was considered to be consistent with the industry-average distribution obtained from the ICES data analysis.

Table 7. Standby TDP unplanned demand performance comparison with industry-average performance.

\begin{tabular}{|c|c|c|c|c|c|c|}
\hline Failure Modes & Plants & $\begin{array}{l}\text { Demands } \\
\text { or Hours }\end{array}$ & Failures & $\begin{array}{l}\text { Expected } \\
\text { Failures }\end{array}$ & $\begin{array}{l}\text { Probability } \\
\text { of } \\
\geq \text { Failures }\end{array}$ & $\begin{array}{l}\text { Consistent with } \\
\text { Industry-Average } \\
\text { Performance? }^{\text {a }}\end{array}$ \\
\hline FTS & 98 & 577 & 4 & 3.7 & 0.38 & Yes \\
\hline $\mathrm{FTR} \leq 1 \mathrm{H}$ & 98 & 347 & 7 & 1.5 & 0.03 & No \\
\hline FTR $>1 \mathrm{H}$ & 98 & 737 & 1 & 1.1 & 0.66 & Yes \\
\hline
\end{tabular}

a. If the probability of observing the actual failures or greater is $\geq 0.05$ and $\leq 0.95$, then the manufacturer performance is considered to be consistent with the industry-average performance.

The unplanned demand FTS and FTR $>1 \mathrm{H}$ are consistent with the industry-average distribution. The unplanned demand failure mode observation FTR $\leq 1 \mathrm{H}$ is not consistent and lies in the lower $95 \%$ (degraded performance) meaning that the TDP performs worse on an unexpected demand than predicted by the industry-average failure rate distribution.

\subsection{TDP Engineering Analysis by Failure Modes}

The engineering analysis of TDP failure sub-components, causes, detection methods, and recovery possibility are presented in this section. First, each analysis divides the events into two categories: standby and normally running TDPs. Note that the FTR $\leq 1 \mathrm{H}$ failure mode only applies to standby TDPs and therefore only shows the Standby category data. 
The second division of the events is by the failure mode determined after ICES data review by the staff. See Section 0 for more description of failure modes.

TDP sub-component contributions to the three failure modes are presented in Figure 19. The subcomponent contributions are similar to those used in the CCF database. The driver (specifically the governor) has the highest percentage contributions to failures for all three failure modes.

TDP cause group contributions to the three failure modes are presented in Figure 20. The cause groups are similar to those used in the CCF database. Table 8 shows the breakdown of the cause groups with the specific causes that were coded during the data collection. The most likely causes are human errors, design issues, and internal faults. Internal means that the cause was related to something within the TDP component such as a worn out part or the normal internal environment. The human cause group is primarily influenced by maintenance and operating procedures and practices. The design cause group is influenced by manufacturing, installation, and design issues.

TDP detection methods to the three failure modes are presented in Figure 21. There are differences in the detection method based on the Standby and normally running categories.

Standby - the most likely detection method for all three failure modes is testing. Inspection is also important for the FTS failure mode. The incidence of inspection for the FTS failure mode indicates that the equipment was observed to be unable to start without a demand (e.g., an alarmed condition, leaking oil, state of another component, etc.).

Normally running - the most likely detection method for FTR is non-testing. The prevalent FTS detection is non-test demands.

TDP recovery to the three failure modes are presented in Figure 22. The overall non-recovery to recovery ratio is approximately $4: 1$. 
Table 8. Component failure cause groups.

\begin{tabular}{|c|c|c|}
\hline Group & Specific Cause & Description \\
\hline \multirow[t]{3}{*}{ Design } & $\begin{array}{l}\text { Construction/installation } \\
\text { error or inadequacy }\end{array}$ & $\begin{array}{l}\text { Used when a construction or installation error is made during } \\
\text { the original or modification installation. This includes } \\
\text { specification of incorrect component or material. }\end{array}$ \\
\hline & $\begin{array}{l}\text { Design error or } \\
\text { inadequacy }\end{array}$ & Used when a design error is made. \\
\hline & $\begin{array}{l}\text { Manufacturing error or } \\
\text { inadequacy }\end{array}$ & $\begin{array}{l}\text { Used when a manufacturing error is made during component } \\
\text { manufacture. }\end{array}$ \\
\hline \multirow[t]{2}{*}{ External } & State of other component & $\begin{array}{l}\text { Used when the cause of a failure is the result of a component } \\
\text { state that is not associated with the component that failed. An } \\
\text { example would be the diesel failed due to no fuel in the fuel } \\
\text { storage tanks. }\end{array}$ \\
\hline & $\begin{array}{l}\text { Ambient environmental } \\
\text { stress }\end{array}$ & $\begin{array}{l}\text { Used when the cause of a failure is the result of an } \\
\text { environmental condition from the location of the component. }\end{array}$ \\
\hline \multirow[t]{3}{*}{ Human } & $\begin{array}{l}\text { Accidental action } \\
\text { (unintentional or undesired } \\
\text { human errors) }\end{array}$ & $\begin{array}{l}\text { Used when a human error (during the performance of an } \\
\text { activity) results in an unintentional or undesired action. }\end{array}$ \\
\hline & Human action procedure & $\begin{array}{l}\text { Used when the procedure is not followed or the procedure is } \\
\text { incorrect. For example: when a missed step or incorrect step } \\
\text { in a surveillance procedure results in a component failure. }\end{array}$ \\
\hline & Inadequate maintenance & $\begin{array}{l}\text { Used when a human error (during the performance of } \\
\text { maintenance) results in an unintentional or undesired action. }\end{array}$ \\
\hline \multirow[t]{4}{*}{ Internal } & $\begin{array}{l}\text { Internal to component, } \\
\text { piece-part }\end{array}$ & $\begin{array}{l}\text { Used when the cause of a failure is a non-specific result of a } \\
\text { failure internal to the component that failed other than aging } \\
\text { or wear. }\end{array}$ \\
\hline & Internal environment & $\begin{array}{l}\text { The internal environment led to the failure. Debris/Foreign } \\
\text { material as well as an operating medium chemistry issue. }\end{array}$ \\
\hline & Set point drift & $\begin{array}{l}\text { Used when the cause of a failure is the result of set point drift } \\
\text { or adjustment. }\end{array}$ \\
\hline & Age/Wear & $\begin{array}{l}\text { Used when the cause of the failure is a non-specific aging or } \\
\text { wear issue. }\end{array}$ \\
\hline \multirow[t]{2}{*}{ Other } & Unknown & Used when the cause of the failure is not known. \\
\hline & $\begin{array}{l}\text { Other (stated cause does } \\
\text { not fit other categories) }\end{array}$ & $\begin{array}{l}\text { Used when the cause of a failure is provided but it does not } \\
\text { meet any one of the descriptions. }\end{array}$ \\
\hline Procedure & Inadequate procedure & $\begin{array}{l}\text { Used when the cause of a failure is the result of an } \\
\text { inadequate procedure operating or maintenance. }\end{array}$ \\
\hline
\end{tabular}



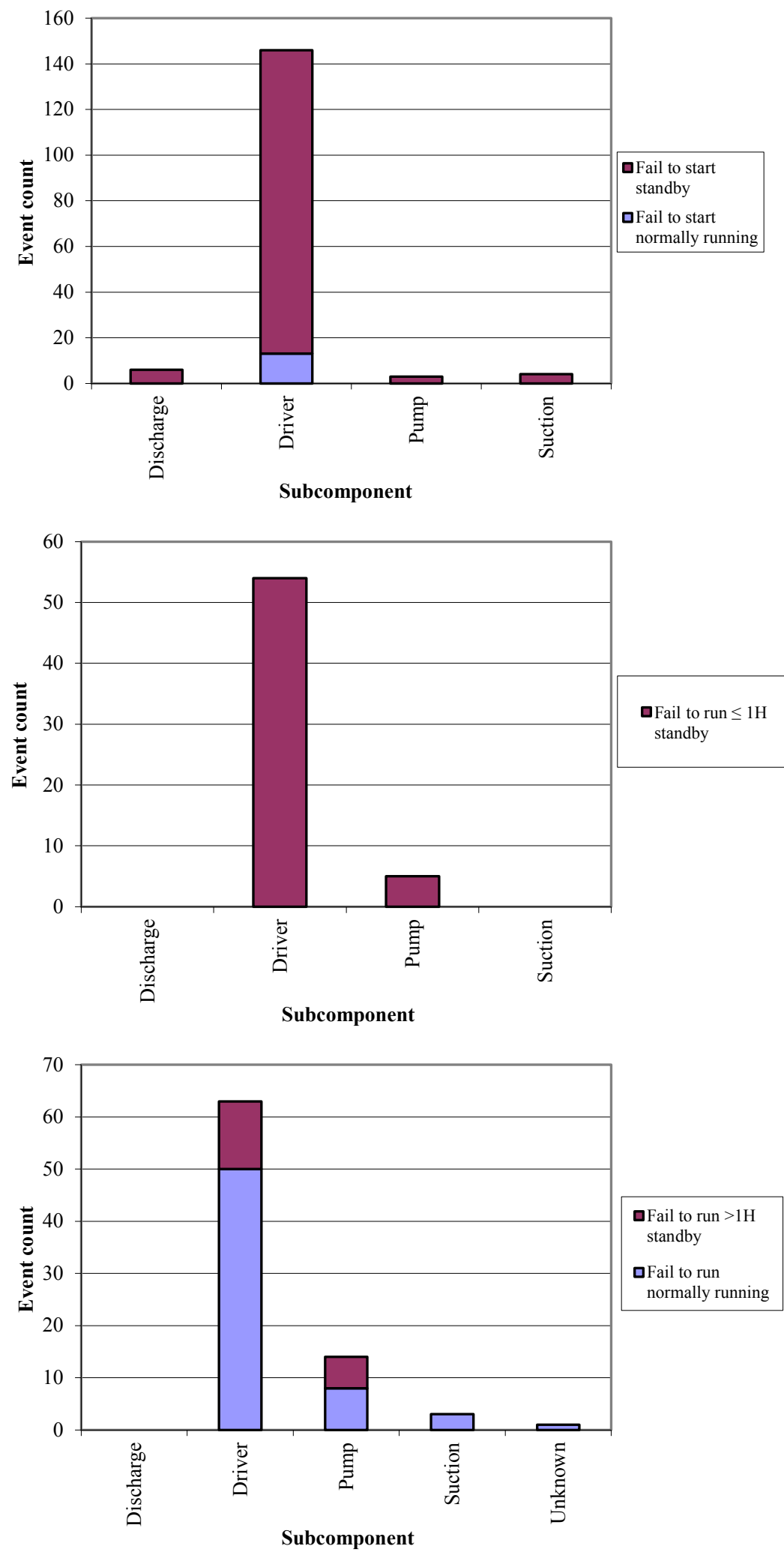

Figure 19. TDP failure event breakdown by subcomponent, failure mode, and operational status. 

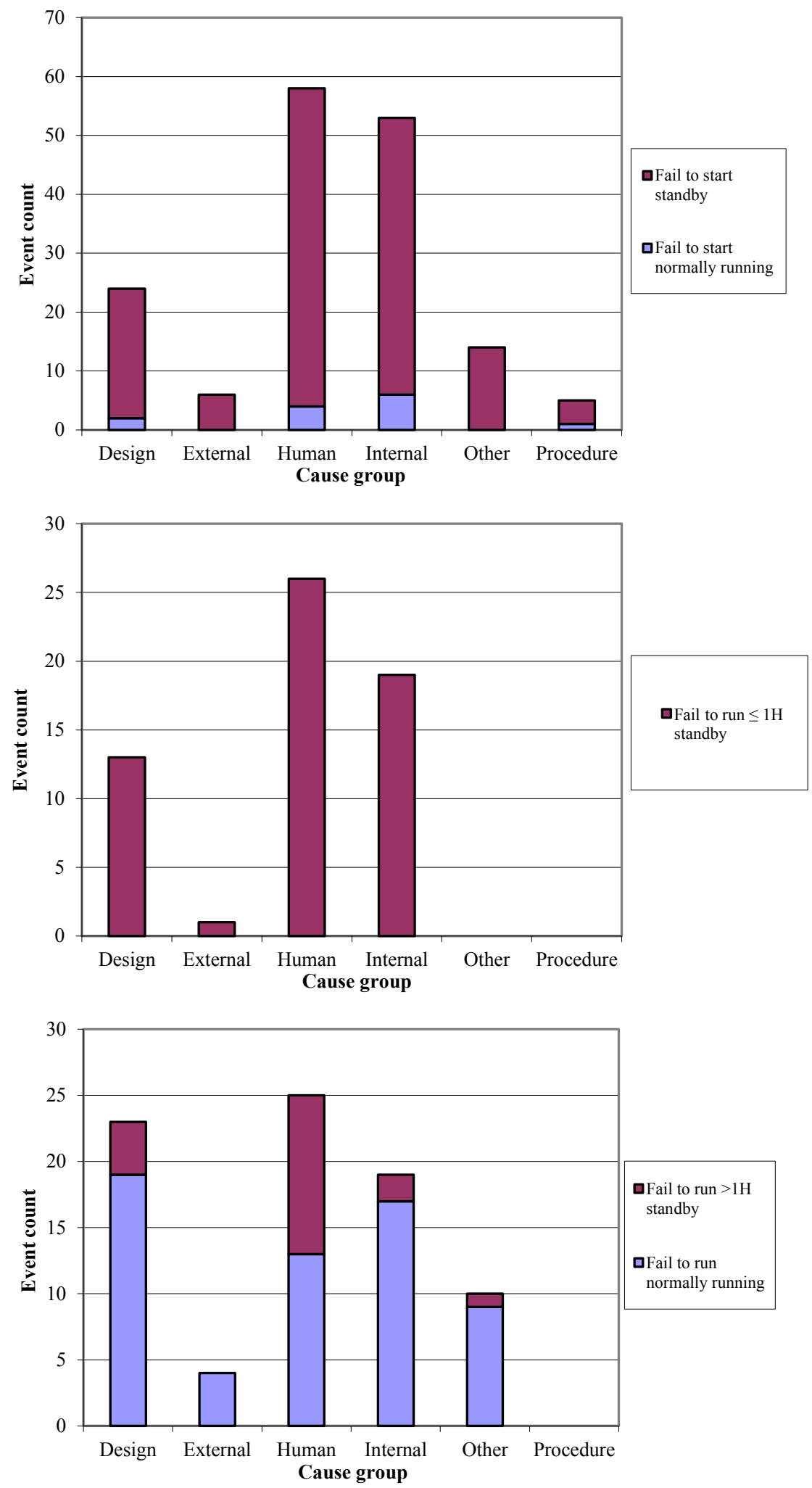

Figure 20. TDP failure event breakdown by cause group, failure mode, and operational status. 

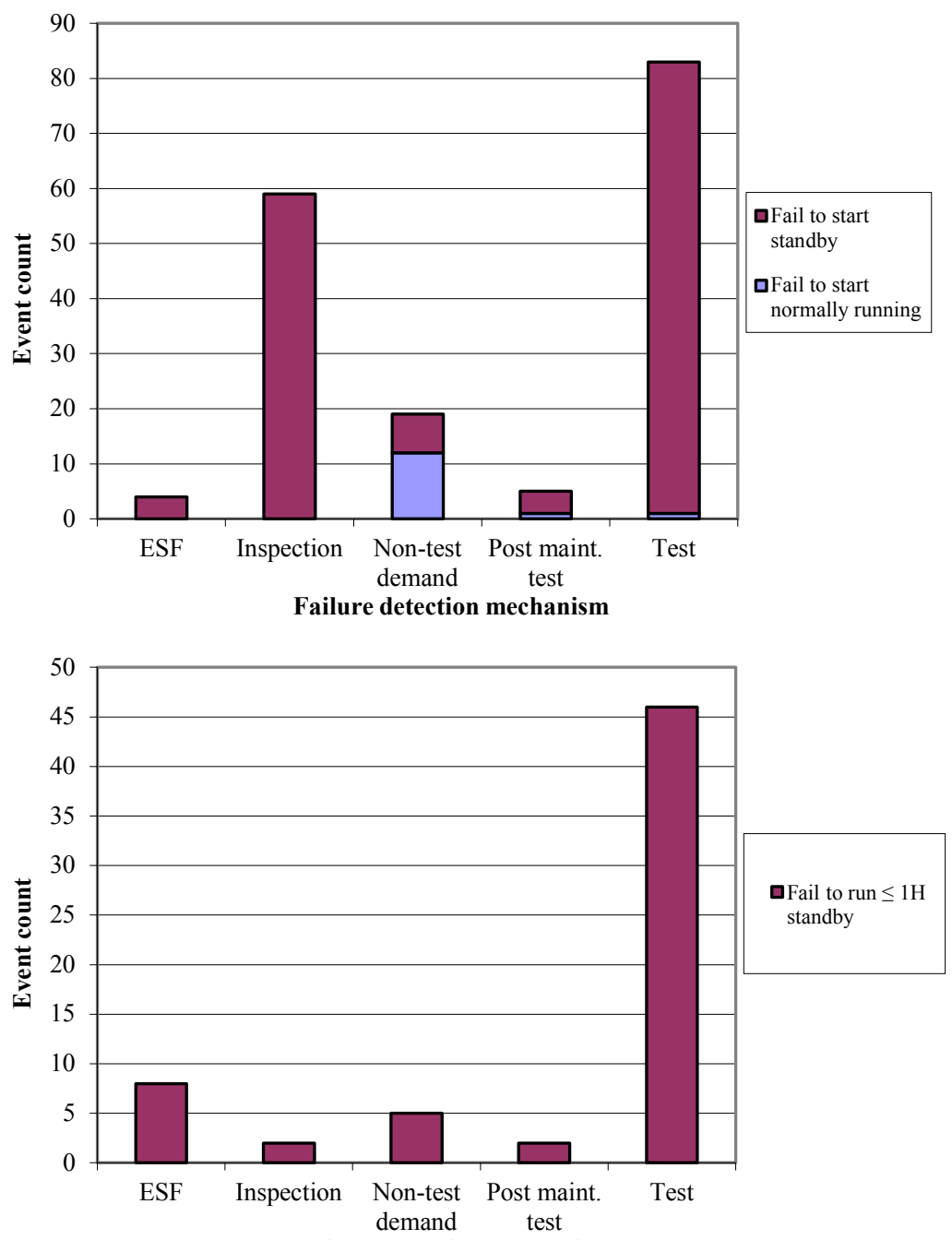

Failure detection mechanism

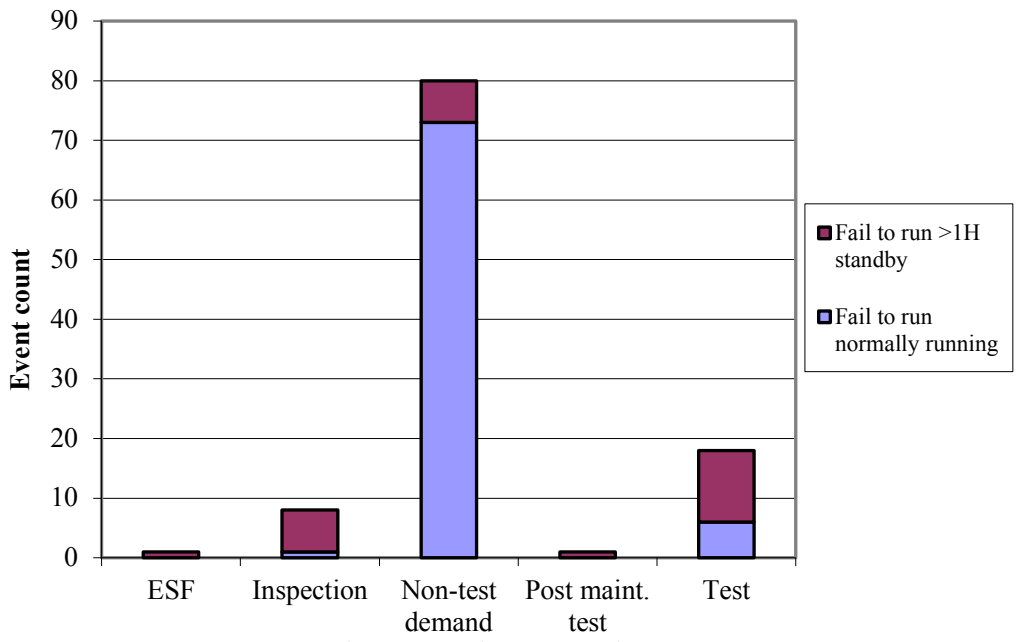

Failure detection mechanism

Figure 21. TDP failure event breakdown by failure detection method, failure mode, and operational status. 

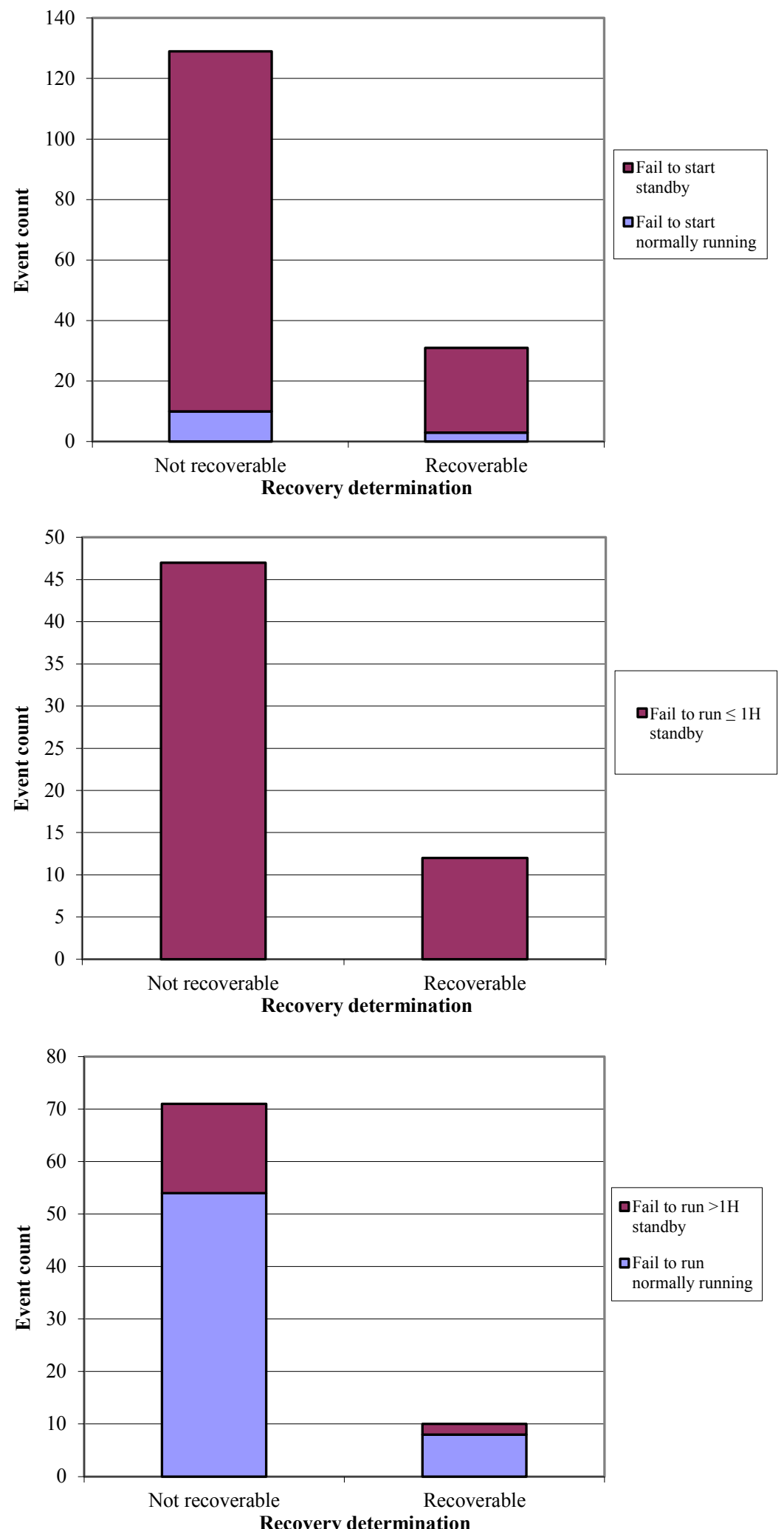

Figure 22. TDP failure event breakdown by recoverability determination, failure mode, and operational status. 


\section{TDP ASSEMBLY DESCRIPTION}

The TDP is generally comprised of a pump, a turbine driver, and a governor. Most plant designs use a single stage "Terry Turbine", whose piece-parts include a turbine trip and throttle valve, a mechanical over speed trip mechanism, and a lubrication system. The various types of governors, used for turbine speed control are mostly manufactured by the Woodward Corporation. For the AFW system TDP, the governors are predominantly mechanical/hydraulic; pressure-compensated, and have a pneumatic remote speed-setting capability. For the RCIC and HPCI systems, the TDPs typically have a Woodward type EG-M electric/electronic governor and EG-R hydraulic actuators. Piece-parts of all governors include a turbine stop valve and a governor valve, while the EG-M usually includes a ramp generator/signal converter and other electrical controls.

The TDP failure modes include FTS, FTR $\leq 1 \mathrm{H}$, and FTR $>1 \mathrm{H}$. These failure modes were used in NUREG/CR-6928 [5] and are similar to those used in the MSPI Program.

Guidelines for determining whether a component event reported in ICES is to be included in FTS, FTR $\leq 1 \mathrm{H}$, or FTR $>1 \mathrm{H}$ are similar to those used in the MSPI Program. In general, any circumstance in which the component is not able to meet the performance requirements defined in the PRA is counted. This includes conditions revealed through testing, operational demands, unplanned demands, or discovery. Also, run failures that occur beyond the typical 24-hour mission time in PRAs are included. However, certain events are excluded: slow starting times that do not exceed the PRA success criteria, conditions that are annunciated immediately in the control room without a demand, and run events that are shown to not have caused an actual run failure within 24 hours. Also, events occurring during maintenance or post-maintenance testing that are related to the actual maintenance activities are excluded. All of the TDP events within ICES were reviewed to ensure that they were binned to the correct failure mode-FTS, FTR $\leq 1 \mathrm{H}, \mathrm{FTR}>1 \mathrm{H}$, or no failure. However, even given detailed descriptions of failure events, this binning still required some judgment and involves some uncertainty.

Guidelines for counting demands and run hours are similar to those in the MSPI Program. Start and run demands include those resulting from tests, operational demands, and unplanned demands. Demands during maintenance and post-maintenance testing are excluded. Similarly, run hours include those from tests, operational demands, and unplanned demands. 
Enhanced Component Performance Study 


\section{DATA TABLES}

Table 9. Plot data for Figure 1, standby TDP FTS industry trend.

\begin{tabular}{|c|c|c|c|c|c|c|c|c|}
\hline \multirow[b]{2}{*}{$\mathbf{F Y}$} & \multirow[b]{2}{*}{ Failures } & \multirow[b]{2}{*}{ Demands } & \multicolumn{3}{|c|}{ Regression Curve Data Points } & \multicolumn{3}{|c|}{ Yearly Estimate Data Points } \\
\hline & & & Mean & $\begin{array}{c}\text { Lower } \\
(\mathbf{5 \% )}\end{array}$ & $\begin{array}{l}\text { Upper } \\
(95 \%)\end{array}$ & $\begin{array}{c}\text { Lower } \\
(5 \%)\end{array}$ & $\begin{array}{l}\text { Upper } \\
(95 \%)\end{array}$ & Mean \\
\hline \multicolumn{2}{|c|}{2010 Update } & & & & & $2.86 \mathrm{E}-04$ & $1.99 \mathrm{E}-02$ & $6.49 \mathrm{E}-03$ \\
\hline 1998 & 2 & $1,538.0$ & & & & $3.51 \mathrm{E}-04$ & 4.33E-03 & $1.54 \mathrm{E}-03$ \\
\hline 1999 & 19 & $1,424.6$ & & & & 8.53E-03 & $1.88 \mathrm{E}-02$ & $1.29 E-02$ \\
\hline 2000 & 17 & $1,473.4$ & & & & 7.23E-03 & 1.67E-02 & $1.12 \mathrm{E}-02$ \\
\hline 2001 & 5 & $1,381.0$ & & & & $1.56 \mathrm{E}-03$ & $7.62 \mathrm{E}-03$ & $3.75 E-03$ \\
\hline 2002 & 5 & $1,403.0$ & & & & $1.54 \mathrm{E}-03$ & 7.50E-03 & 3.70E-03 \\
\hline 2003 & 8 & $1,541.2$ & & & & 2.67E-03 & $9.25 \mathrm{E}-03$ & $5.23 E-03$ \\
\hline 2004 & 10 & $1,466.2$ & & & & $3.74 \mathrm{E}-03$ & 1.13E-02 & 6.77E-03 \\
\hline 2005 & 8 & $1,492.3$ & $5.51 \mathrm{E}-03$ & $3.25 \mathrm{E}-03$ & $9.32 \mathrm{E}-03$ & $2.75 \mathrm{E}-03$ & $9.54 \mathrm{E}-03$ & 5.39E-03 \\
\hline 2006 & 6 & $1,453.2$ & 5.53E-03 & 3.54E-03 & 8.64E-03 & $1.92 \mathrm{E}-03$ & 8.11E-03 & 4.23E-03 \\
\hline 2007 & 9 & $1,468.4$ & $5.55 \mathrm{E}-03$ & 3.81E-03 & 8.08E-03 & 3.26E-03 & 1.05E-02 & $6.12 \mathrm{E}-03$ \\
\hline 2008 & 8 & $1,450.8$ & 5.58E-03 & 4.05E-03 & 7.67E-03 & 2.83E-03 & $9.80 \mathrm{E}-03$ & 5.54E-03 \\
\hline 2009 & 15 & $1,546.7$ & 5.60E-03 & 4.21E-03 & 7.44E-03 & 5.92E-03 & $1.45 \mathrm{E}-02$ & 9.51E-03 \\
\hline 2010 & 10 & $1,607.5$ & 5.62E-03 & 4.24E-03 & $7.45 \mathrm{E}-03$ & $3.43 E-03$ & 1.04E-02 & $6.21 \mathrm{E}-03$ \\
\hline 2011 & 7 & $1,595.1$ & 5.65E-03 & 4.14E-03 & 7.70E-03 & 2.16E-03 & 8.20E-03 & 4.46E-03 \\
\hline 2012 & 8 & $1,514.1$ & 5.67E-03 & 3.94E-03 & 8.15E-03 & 2.71E-03 & 9.41E-03 & 5.32E-03 \\
\hline 2013 & 5 & $1,622.0$ & 5.69E-03 & 3.69E-03 & 8.77E-03 & 1.34E-03 & 6.54E-03 & $3.22 E-03$ \\
\hline 2014 & 14 & $1,513.1$ & $5.71 \mathrm{E}-03$ & $3.42 E-03$ & 9.52E-03 & 5.55E-03 & $1.41 \mathrm{E}-02$ & 9.08E-03 \\
\hline Total & 156 & $25,490.9$ & & & & & & \\
\hline
\end{tabular}


Table 10. Plot data for Figure 2, standby TDP FTR $\leq 1 \mathrm{H}$ industry trend.

\begin{tabular}{|c|c|c|c|c|c|c|c|c|}
\hline \multirow[b]{2}{*}{$\mathbf{F Y}$} & \multirow[b]{2}{*}{ Failures } & \multirow[b]{2}{*}{ Demands } & \multicolumn{3}{|c|}{ Regression Curve Data Points } & \multicolumn{3}{|c|}{ Yearly Estimate Data Points } \\
\hline & & & Mean & $\begin{array}{c}\text { Lower } \\
(5 \%)\end{array}$ & $\begin{array}{l}\text { Upper } \\
(95 \%)\end{array}$ & $\begin{array}{c}\text { Lower } \\
(5 \%)\end{array}$ & $\begin{array}{l}\text { Upper } \\
(95 \%)\end{array}$ & Mean \\
\hline \multicolumn{2}{|c|}{2010 Update } & & & & & 2.06E-04 & $1.34 \mathrm{E}-02$ & $4.43 \mathrm{E}-03$ \\
\hline 1998 & 2 & $1,538.0$ & & & & 3.20E-04 & 3.93E-03 & $1.40 \mathrm{E}-03$ \\
\hline 1999 & 4 & $1,424.6$ & & & & 9.93E-04 & $5.87 \mathrm{E}-03$ & $2.69 \mathrm{E}-03$ \\
\hline 2000 & 6 & $1,473.4$ & & & & $1.71 \mathrm{E}-03$ & $7.25 \mathrm{E}-03$ & 3.77E-03 \\
\hline 2001 & 6 & $1,381.0$ & & & & $1.81 \mathrm{E}-03$ & $7.66 \mathrm{E}-03$ & $3.98 \mathrm{E}-03$ \\
\hline 2002 & 3 & $1,403.0$ & & & & $6.55 \mathrm{E}-04$ & $5.12 \mathrm{E}-03$ & $2.12 \mathrm{E}-03$ \\
\hline 2003 & 9 & $1,541.2$ & & & & 2.82E-03 & $9.12 \mathrm{E}-03$ & $5.30 \mathrm{E}-03$ \\
\hline 2004 & 3 & $1,466.2$ & & & & $6.31 \mathrm{E}-04$ & 4.93E-03 & $2.04 \mathrm{E}-03$ \\
\hline 2005 & 3 & $1,492.3$ & $2.79 \mathrm{E}-03$ & $9.41 \mathrm{E}-04$ & $8.29 \mathrm{E}-03$ & $6.22 \mathrm{E}-04$ & $4.85 \mathrm{E}-03$ & $2.01 \mathrm{E}-03$ \\
\hline 2006 & 1 & $1,453.2$ & $2.41 \mathrm{E}-03$ & $9.67 \mathrm{E}-04$ & $6.02 \mathrm{E}-03$ & 1.03E-04 & $3.25 \mathrm{E}-03$ & $8.81 \mathrm{E}-04$ \\
\hline 2007 & 6 & $1,468.4$ & $2.08 \mathrm{E}-03$ & $9.64 \mathrm{E}-04$ & $4.51 \mathrm{E}-03$ & $1.71 \mathrm{E}-03$ & $7.27 \mathrm{E}-03$ & $3.78 \mathrm{E}-03$ \\
\hline 2008 & 5 & $1,450.8$ & $1.80 \mathrm{E}-03$ & $9.15 \mathrm{E}-04$ & 3.54E-03 & $1.34 \mathrm{E}-03$ & $6.57 \mathrm{E}-03$ & $3.23 \mathrm{E}-03$ \\
\hline 2009 & 6 & $1,546.7$ & $1.56 \mathrm{E}-03$ & $8.09 \mathrm{E}-04$ & 2.99E-03 & $1.64 \mathrm{E}-03$ & $6.96 \mathrm{E}-03$ & $3.62 \mathrm{E}-03$ \\
\hline 2010 & 2 & $1,607.5$ & $1.34 \mathrm{E}-03$ & $6.61 \mathrm{E}-04$ & $2.73 \mathrm{E}-03$ & $3.08 \mathrm{E}-04$ & $3.79 \mathrm{E}-03$ & $1.35 \mathrm{E}-03$ \\
\hline 2011 & 4 & $1,595.1$ & $1.16 \mathrm{E}-03$ & $5.08 \mathrm{E}-04$ & $2.65 \mathrm{E}-03$ & $9.01 \mathrm{E}-04$ & $5.33 \mathrm{E}-03$ & 2.44E-03 \\
\hline 2012 & 3 & $1,514.1$ & $1.00 \mathrm{E}-03$ & $3.75 \mathrm{E}-04$ & $2.68 \mathrm{E}-03$ & $6.14 \mathrm{E}-04$ & $4.79 \mathrm{E}-03$ & $1.98 \mathrm{E}-03$ \\
\hline 2013 & 0 & $1,622.0$ & $8.66 \mathrm{E}-04$ & $2.70 \mathrm{E}-04$ & $2.78 \mathrm{E}-03$ & $1.05 \mathrm{E}-06$ & $2.09 \mathrm{E}-03$ & 2.67E-04 \\
\hline 2014 & 0 & $1,513.1$ & $7.48 \mathrm{E}-04$ & $1.92 \mathrm{E}-04$ & 2.92E-03 & $1.11 \mathrm{E}-06$ & 2.22E-03 & $2.84 \mathrm{E}-04$ \\
\hline Total & 63 & $25,490.9$ & & & & & & \\
\hline
\end{tabular}


Table 11. Plot data for Figure 3, standby TDP FTR $>1 H$ industry trend.

\begin{tabular}{|c|c|c|c|c|c|c|c|c|}
\hline \multirow[b]{2}{*}{ FY } & \multirow[b]{2}{*}{ Failures } & \multirow[b]{2}{*}{ Hours } & \multicolumn{3}{|c|}{ Regression Curve Data Points } & \multicolumn{3}{|c|}{ Yearly Estimate Data Points } \\
\hline & & & Mean & $\begin{array}{c}\text { Lower } \\
(5 \%)\end{array}$ & $\begin{array}{l}\text { Upper } \\
(95 \%)\end{array}$ & $\begin{array}{c}\text { Lower } \\
(5 \%)\end{array}$ & $\begin{array}{l}\text { Upper } \\
(95 \%)\end{array}$ & Mean \\
\hline \multicolumn{2}{|c|}{2010 Update } & & & & & $9.12 \mathrm{E}-04$ & $2.35 \mathrm{E}-03$ & $1.56 \mathrm{E}-03$ \\
\hline 1998 & 3 & 420.5 & & & & 2.17E-03 & 1.69E-02 & 7.01E-03 \\
\hline 1999 & 0 & $2,590.3$ & & & & 7.37E-07 & $1.46 \mathrm{E}-03$ & $1.87 \mathrm{E}-04$ \\
\hline 2000 & 0 & 604.5 & & & & $2.88 \mathrm{E}-06$ & $5.72 \mathrm{E}-03$ & 7.31E-04 \\
\hline 2001 & 1 & 674.4 & & & & 2.33E-04 & 7.35E-03 & $1.99 \mathrm{E}-03$ \\
\hline 2002 & 0 & $1,242.9$ & & & & $1.49 \mathrm{E}-06$ & 2.96E-03 & $3.78 \mathrm{E}-04$ \\
\hline 2003 & 0 & $1,516.5$ & & & & 1.23E-06 & $2.45 \mathrm{E}-03$ & 3.13E-04 \\
\hline 2004 & 4 & 370.2 & & & & $3.70 \mathrm{E}-03$ & 2.19E-02 & 1.00E-02 \\
\hline 2005 & 1 & 281.0 & 3.32E-03 & 8.33E-04 & 1.33E-02 & 4.89E-04 & $1.54 \mathrm{E}-02$ & 4.17E-03 \\
\hline 2006 & 2 & 255.7 & 3.61E-03 & 1.11E-03 & 1.17E-02 & 1.71E-03 & 2.10E-02 & 7.47E-03 \\
\hline 2007 & 1 & 268.0 & 3.91E-03 & $1.45 \mathrm{E}-03$ & 1.05E-02 & 5.07E-04 & 1.60E-02 & 4.32E-03 \\
\hline 2008 & 2 & 306.0 & 4.24E-03 & $1.85 \mathrm{E}-03$ & $9.75 \mathrm{E}-03$ & 1.49E-03 & 1.83E-02 & $6.49 \mathrm{E}-03$ \\
\hline 2009 & 0 & 365.4 & 4.60E-03 & $2.24 \mathrm{E}-03$ & $9.48 \mathrm{E}-03$ & 4.42E-06 & 8.79E-03 & 1.12E-03 \\
\hline 2010 & 0 & 355.7 & 4.99E-03 & $2.52 \mathrm{E}-03$ & 9.91E-03 & 4.52E-06 & 8.99E-03 & 1.15E-03 \\
\hline 2011 & 5 & 426.6 & $5.42 \mathrm{E}-03$ & 2.60E-03 & 1.13E-02 & 4.52E-03 & 2.21E-02 & 1.09E-02 \\
\hline 2012 & 4 & 296.7 & 5.87E-03 & $2.51 \mathrm{E}-03$ & 1.37E-02 & 4.42E-03 & 2.62E-02 & 1.20E-02 \\
\hline 2013 & 3 & 385.6 & 6.37E-03 & 2.31E-03 & 1.76E-02 & 2.33E-03 & 1.82E-02 & 7.53E-03 \\
\hline 2014 & 2 & 299.8 & 6.91E-03 & 2.07E-03 & 2.30E-02 & 1.51E-03 & 1.86E-02 & 6.60E-03 \\
\hline Total & 28 & $10,659.7$ & & & & & & \\
\hline
\end{tabular}


Table 12. Plot data for Figure 4, normally running TDP FTS industry trend.

\begin{tabular}{|c|c|c|c|c|c|c|c|c|}
\hline \multirow[b]{2}{*}{ FY } & \multirow[b]{2}{*}{ Failures } & \multirow[b]{2}{*}{ Demands } & \multicolumn{3}{|c|}{ Regression Curve Data Points } & \multicolumn{3}{|c|}{ Yearly Estimate Data Points } \\
\hline & & & Mean & $\begin{array}{c}\text { Lower } \\
(5 \%)\end{array}$ & $\begin{array}{l}\text { Upper } \\
(95 \%)\end{array}$ & $\begin{array}{c}\text { Lower } \\
(5 \%)\end{array}$ & $\begin{array}{l}\text { Upper } \\
(95 \%)\end{array}$ & Mean \\
\hline \multicolumn{2}{|c|}{2010 Update } & & & & & $3.22 \mathrm{E}-04$ & $2.80 \mathrm{E}-02$ & 8.93E-03 \\
\hline 1998 & 1 & 77.2 & & & & 1.35E-03 & 4.27E-02 & 1.17E-02 \\
\hline 1999 & 3 & 78.7 & & & & 8.41E-03 & 6.43E-02 & 2.71E-02 \\
\hline 2000 & 0 & 78.7 & & & & $1.26 \mathrm{E}-05$ & 2.98E-02 & 3.77E-03 \\
\hline 2001 & 1 & 78.2 & & & & $1.34 \mathrm{E}-03$ & 4.24E-02 & 1.16E-02 \\
\hline 2002 & 0 & 78.2 & & & & 1.27E-05 & 2.99E-02 & 3.79E-03 \\
\hline 2003 & 0 & 77.8 & & & & 1.27E-05 & 3.00E-02 & 3.80E-03 \\
\hline 2004 & 0 & 78.0 & & & & 1.27E-05 & 2.99E-02 & 3.79E-03 \\
\hline 2005 & 3 & 78.2 & $9.25 \mathrm{E}-03$ & 3.08E-03 & 2.74E-02 & 8.44E-03 & 6.46E-02 & 2.72E-02 \\
\hline 2006 & 0 & 78.2 & 8.78E-03 & 3.46E-03 & 2.21E-02 & 1.27E-05 & 2.99E-02 & 3.79E-03 \\
\hline 2007 & 1 & 78.2 & 8.33E-03 & 3.81E-03 & 1.81E-02 & 1.34E-03 & 4.23E-02 & 1.16E-02 \\
\hline 2008 & 0 & 78.1 & 7.91E-03 & 4.05E-03 & $1.54 \mathrm{E}-02$ & 1.27E-05 & 2.99E-02 & 3.79E-03 \\
\hline 2009 & 1 & 78.0 & 7.50E-03 & 4.11E-03 & 1.37E-02 & 1.34E-03 & 4.24E-02 & 1.16E-02 \\
\hline 2010 & 0 & 75.9 & 7.12E-03 & 3.89E-03 & 1.30E-02 & 1.29E-05 & 3.04E-02 & 3.86E-03 \\
\hline 2011 & 0 & 76.0 & 6.75E-03 & 3.44E-03 & 1.32E-02 & 1.29E-05 & 3.04E-02 & 3.85E-03 \\
\hline 2012 & 1 & 76.0 & 6.41E-03 & 2.90E-03 & $1.41 \mathrm{E}-02$ & 1.36E-03 & 4.31E-02 & 1.18E-02 \\
\hline 2013 & 0 & 76.0 & 6.08E-03 & 2.37E-03 & $1.55 \mathrm{E}-02$ & 1.29E-05 & 3.04E-02 & $3.85 \mathrm{E}-03$ \\
\hline 2014 & 1 & 76.1 & 5.77E-03 & $1.90 \mathrm{E}-03$ & 1.74E-02 & $1.36 \mathrm{E}-03$ & 4.30E-02 & 1.18E-02 \\
\hline Total & 12 & $1,317.5$ & & & & & & \\
\hline
\end{tabular}


Table 13. Plot data for Figure 5, normally running TDP FTR industry trend.

\begin{tabular}{|c|c|c|c|c|c|c|c|c|}
\hline \multirow[b]{2}{*}{ FY } & \multirow[b]{2}{*}{ Failures } & \multirow[b]{2}{*}{ Hours } & \multicolumn{3}{|c|}{ Regression Curve Data Points } & \multicolumn{3}{|c|}{ Yearly Estimate Data Points } \\
\hline & & & Mean & $\begin{array}{c}\text { Lower } \\
(5 \%)\end{array}$ & $\begin{array}{l}\text { Upper } \\
(95 \%) \\
\end{array}$ & $\begin{array}{c}\text { Lower } \\
(5 \%)\end{array}$ & $\begin{array}{l}\text { Upper } \\
(95 \%) \\
\end{array}$ & Mean \\
\hline \multicolumn{2}{|c|}{2010 Update } & & & & & $1.43 \mathrm{E}-06$ & $2.29 E-05$ & $9.34 \mathrm{E}-06$ \\
\hline 1998 & 3 & $331,126.2$ & & & & 2.91E-06 & 2.27E-05 & $9.41 \mathrm{E}-06$ \\
\hline 1999 & 4 & $335,021.6$ & & & & $4.42 \mathrm{E}-06$ & 2.62E-05 & $1.20 \mathrm{E}-05$ \\
\hline 2000 & 3 & $335,021.6$ & & & & 2.88E-06 & $2.25 \mathrm{E}-05$ & 9.31E-06 \\
\hline 2001 & 4 & $335,265.0$ & & & & $4.42 \mathrm{E}-06$ & $2.62 \mathrm{E}-05$ & 1.20E-05 \\
\hline 2002 & 3 & $335,432.3$ & & & & 2.88E-06 & 2.25E-05 & $9.30 \mathrm{E}-06$ \\
\hline 2003 & 2 & $335,401.9$ & & & & $1.52 \mathrm{E}-06$ & $1.87 \mathrm{E}-05$ & 6.64E-06 \\
\hline 2004 & 7 & $335,432.3$ & & & & 9.65E-06 & 3.67E-05 & 1.99E-05 \\
\hline 2005 & 5 & $335,356.3$ & 1.06E-05 & 7.04E-06 & 1.61E-05 & $6.08 \mathrm{E}-06$ & 2.97E-05 & 1.46E-05 \\
\hline 2006 & 3 & $335,447.5$ & 1.09E-05 & 7.66E-06 & 1.54E-05 & 2.88E-06 & $2.25 E-05$ & 9.30E-06 \\
\hline 2007 & 3 & $335,417.1$ & 1.11E-05 & 8.27E-06 & 1.49E-05 & 2.88E-06 & 2.25E-05 & 9.30E-06 \\
\hline 2008 & 3 & $335,325.8$ & 1.13E-05 & 8.83E-06 & 1.46E-05 & 2.88E-06 & 2.25E-05 & 9.30E-06 \\
\hline 2009 & 3 & $335,341.1$ & 1.16E-05 & $9.26 \mathrm{E}-06$ & 1.45E-05 & 2.88E-06 & 2.25E-05 & 9.30E-06 \\
\hline 2010 & 6 & $327,256.8$ & 1.18E-05 & 9.49E-06 & 1.47E-05 & 8.00E-06 & 3.39E-05 & 1.77E-05 \\
\hline 2011 & 4 & $327,119.9$ & 1.21E-05 & 9.47E-06 & 1.54E-05 & 4.52E-06 & 2.67E-05 & 1.22E-05 \\
\hline 2012 & 4 & $327,226.4$ & 1.23E-05 & $9.28 \mathrm{E}-06$ & 1.64E-05 & 4.52E-06 & 2.67E-05 & 1.22E-05 \\
\hline 2013 & 6 & $327,043.8$ & 1.26E-05 & 8.98E-06 & 1.77E-05 & 8.01E-06 & 3.40E-05 & 1.77E-05 \\
\hline 2014 & 3 & $327,241.6$ & 1.29E-05 & 8.63E-06 & 1.92E-05 & 2.94E-06 & 2.30E-05 & 9.51E-06 \\
\hline Total & 66 & $5,655,477.2$ & & & & & & \\
\hline
\end{tabular}


Table 14. Plot data for Figure 6, all standby TDP unavailability trend.

\begin{tabular}{|c|c|c|c|c|c|c|c|c|}
\hline \multirow[b]{2}{*}{ FY } & \multirow[b]{2}{*}{$\begin{array}{l}\text { UA } \\
\text { Hours }\end{array}$} & \multirow[b]{2}{*}{$\begin{array}{l}\text { Critical } \\
\text { Hours }\end{array}$} & \multicolumn{3}{|c|}{ Regression Curve Data Points } & \multicolumn{3}{|c|}{ Yearly Estimate Data Points } \\
\hline & & & Mean & $\begin{array}{c}\text { Lower } \\
(5 \%)\end{array}$ & $\begin{array}{l}\text { Upper } \\
(95 \%)\end{array}$ & $\begin{array}{l}\text { Lower } \\
(5 \%)\end{array}$ & $\begin{array}{l}\text { Upper } \\
(95 \%)\end{array}$ & Mean \\
\hline \multicolumn{2}{|c|}{2010 Update } & & & & & $9.04 \mathrm{E}-04$ & $1.28 \mathrm{E}-02$ & $5.33 E-03$ \\
\hline 1998 & 8,366 & 641,458 & & & & $1.83 \mathrm{E}-06$ & 6.69E-02 & 1.47E-02 \\
\hline 1999 & 8,254 & 922,022 & & & & 4.93E-04 & 2.73E-02 & $9.21 \mathrm{E}-03$ \\
\hline 2000 & 7,840 & 954,887 & & & & 8.59E-04 & 2.18E-02 & 8.21E-03 \\
\hline 2001 & 7,560 & 959,741 & & & & 2.72E-04 & $2.53 \mathrm{E}-02$ & 8.02E-03 \\
\hline 2002 & 7,612 & 961,200 & & & & $5.77 \mathrm{E}-04$ & $2.26 \mathrm{E}-02$ & 7.98E-03 \\
\hline 2003 & 8,559 & 942,160 & & & & 1.13E-03 & 2.34E-02 & $9.11 \mathrm{E}-03$ \\
\hline 2004 & 7,527 & 970,566 & & & & 5.94E-04 & 2.22E-02 & 7.87E-03 \\
\hline 2005 & 6,184 & 956,879 & 7.09E-03 & $6.28 \mathrm{E}-03$ & 8.01E-03 & $1.28 \mathrm{E}-03$ & $1.53 \mathrm{E}-02$ & $6.60 \mathrm{E}-03$ \\
\hline 2006 & 6,817 & 973,031 & 7.26E-03 & 6.60E-03 & 7.98E-03 & 7.87E-04 & $1.84 \mathrm{E}-02$ & 7.00E-03 \\
\hline 2007 & 7,124 & 969,478 & 7.42E-03 & 6.94E-03 & 7.94E-03 & $1.44 \mathrm{E}-04$ & $2.50 \mathrm{E}-02$ & 7.44E-03 \\
\hline 2008 & 7,489 & 971,347 & 7.59E-03 & 7.29E-03 & 7.91E-03 & 1.23E-05 & 3.13E-02 & 7.72E-03 \\
\hline 2009 & 7,854 & 967,222 & 7.77E-03 & 7.66E-03 & 7.87E-03 & 2.64E-05 & 3.23E-02 & 8.32E-03 \\
\hline 2010 & 7,956 & 953,467 & 7.94E-03 & 7.84E-03 & 8.05E-03 & $1.06 \mathrm{E}-03$ & 2.16E-02 & 8.44E-03 \\
\hline 2011 & 7,837 & 943,250 & 8.13E-03 & 7.80E-03 & 8.46E-03 & 5.78E-04 & 2.42E-02 & 8.46E-03 \\
\hline 2012 & 8,055 & 933,925 & 8.31E-03 & 7.77E-03 & 8.89E-03 & 6.36E-04 & 2.41E-02 & 8.53E-03 \\
\hline 2013 & 8,018 & 915,795 & 8.50E-03 & 7.73E-03 & 9.34E-03 & 1.16E-09 & 4.79E-02 & 8.94E-03 \\
\hline 2014 & 6,940 & 936,639 & 8.70E-03 & 7.70E-03 & 9.82E-03 & 2.62E-04 & 2.33E-02 & 7.42E-03 \\
\hline Total & 129,990 & $15,873,069$ & & & & & & \\
\hline
\end{tabular}


Table 15. Plot data for Figure 7, standby TDP unreliability trend.

\begin{tabular}{|c|c|c|c|c|c|c|}
\hline \multirow[b]{2}{*}{ FY } & \multicolumn{3}{|c|}{ Regression Curve Data Points } & \multicolumn{3}{|c|}{ Yearly Estimate Data Points } \\
\hline & Mean & Lower (5\%) & Upper (95\%) & Lower (5\%) & Upper (95\%) & Mean \\
\hline 1998 & & & & 1.93E-02 & 1.21E-01 & 5.61E-02 \\
\hline 1999 & & & & $1.51 \mathrm{E}-02$ & 4.38E-02 & 2.62E-02 \\
\hline 2000 & & & & $1.55 \mathrm{E}-02$ & 4.61E-02 & 2.79E-02 \\
\hline 2001 & & & & 1.18E-02 & 5.37E-02 & 2.89E-02 \\
\hline 2002 & & & & 6.87E-03 & 3.29E-02 & 1.66E-02 \\
\hline 2003 & & & & $1.20 \mathrm{E}-02$ & 3.68E-02 & 2.22E-02 \\
\hline 2004 & & & & 3.49E-02 & 1.18E-01 & 7.15E-02 \\
\hline 2005 & 3.64E-02 & 2.02E-02 & $6.46 \mathrm{E}-02$ & $1.50 \mathrm{E}-02$ & 7.04E-02 & 3.56E-02 \\
\hline 2006 & $3.82 \mathrm{E}-02$ & 2.32E-02 & $6.22 \mathrm{E}-02$ & 1.96E-02 & 9.49E-02 & 5.03E-02 \\
\hline 2007 & 4.01E-02 & 2.64E-02 & 6.04E-02 & 1.59E-02 & $7.82 \mathrm{E}-02$ & 3.98E-02 \\
\hline 2008 & 4.21E-02 & 2.95E-02 & 5.96E-02 & 1.94E-02 & $9.55 \mathrm{E}-02$ & 5.04E-02 \\
\hline 2009 & $4.41 \mathrm{E}-02$ & 3.21E-02 & 6.04E-02 & $1.29 \mathrm{E}-02$ & 5.64E-02 & 2.81E-02 \\
\hline 2010 & 4.63E-02 & 3.37E-02 & 6.33E-02 & $9.18 \mathrm{E}-03$ & 4.36E-02 & 2.18E-02 \\
\hline 2011 & 4.86E-02 & 3.42E-02 & 6.87E-02 & 3.93E-02 & $1.21 \mathrm{E}-01$ & 7.43E-02 \\
\hline 2012 & 5.10E-02 & 3.37E-02 & 7.64E-02 & 3.98E-02 & $1.29 \mathrm{E}-01$ & 7.76E-02 \\
\hline 2013 & 5.35E-02 & 3.27E-02 & 8.62E-02 & 1.78E-02 & $1.08 \mathrm{E}-01$ & 5.35E-02 \\
\hline 2014 & 5.61E-02 & 3.14E-02 & 9.81E-02 & 2.23E-02 & $9.28 \mathrm{E}-02$ & 5.08E-02 \\
\hline
\end{tabular}


Table 16. Plot data for Figure 8, NR TDP unreliability trend.

\begin{tabular}{ccccccc}
\hline & \multicolumn{2}{c}{ Regression Curve Data Points } & \multicolumn{3}{c}{ Yearly Estimate Data Points } \\
\cline { 2 - 6 } FY & Mean & Lower (5\%) & Upper (95\%) & $\begin{array}{c}\text { Lower } \\
\mathbf{( 5 \% )}\end{array}$ & $\begin{array}{l}\text { Upper } \\
\mathbf{( 9 5 \% )}\end{array}$ & Mean \\
\hline 1998 & & & & $1.51 \mathrm{E}-03$ & $3.18 \mathrm{E}-02$ & $1.22 \mathrm{E}-02$ \\
1999 & & & & $8.44 \mathrm{E}-03$ & $5.15 \mathrm{E}-02$ & $2.58 \mathrm{E}-02$ \\
\hline 2000 & & & & $1.00 \mathrm{E}-04$ & $1.46 \mathrm{E}-02$ & $4.08 \mathrm{E}-03$ \\
\hline 2001 & & & & $1.49 \mathrm{E}-03$ & $3.11 \mathrm{E}-02$ & $1.17 \mathrm{E}-02$ \\
\hline 2002 & & & & $8.20 \mathrm{E}-05$ & $1.40 \mathrm{E}-02$ & $3.90 \mathrm{E}-03$ \\
\hline 2003 & & & & $6.92 \mathrm{E}-05$ & $1.39 \mathrm{E}-02$ & $3.86 \mathrm{E}-03$ \\
\hline 2004 & & & & $1.66 \mathrm{E}-04$ & $1.49 \mathrm{E}-02$ & $3.98 \mathrm{E}-03$ \\
\hline 2005 & $9.24 \mathrm{E}-03$ & $3.31 \mathrm{E}-03$ & $2.55 \mathrm{E}-02$ & $8.09 \mathrm{E}-03$ & $5.02 \mathrm{E}-02$ & $2.55 \mathrm{E}-02$ \\
\hline 2006 & $8.80 \mathrm{E}-03$ & $3.69 \mathrm{E}-03$ & $2.09 \mathrm{E}-02$ & $9.01 \mathrm{E}-05$ & $1.54 \mathrm{E}-02$ & $4.08 \mathrm{E}-03$ \\
\hline 2007 & $8.39 \mathrm{E}-03$ & $4.03 \mathrm{E}-03$ & $1.74 \mathrm{E}-02$ & $1.37 \mathrm{E}-03$ & $2.97 \mathrm{E}-02$ & $1.13 \mathrm{E}-02$ \\
\hline 2008 & $7.99 \mathrm{E}-03$ & $4.28 \mathrm{E}-03$ & $1.49 \mathrm{E}-02$ & $8.55 \mathrm{E}-05$ & $1.45 \mathrm{E}-02$ & $3.95 \mathrm{E}-03$ \\
\hline 2009 & $7.61 \mathrm{E}-03$ & $4.34 \mathrm{E}-03$ & $1.33 \mathrm{E}-02$ & $1.42 \mathrm{E}-03$ & $3.06 \mathrm{E}-02$ & $1.18 \mathrm{E}-02$ \\
\hline 2010 & $7.25 \mathrm{E}-03$ & $4.14 \mathrm{E}-03$ & $1.27 \mathrm{E}-02$ & $1.46 \mathrm{E}-04$ & $1.40 \mathrm{E}-02$ & $3.98 \mathrm{E}-03$ \\
\hline 2011 & $6.91 \mathrm{E}-03$ & $3.70 \mathrm{E}-03$ & $1.29 \mathrm{E}-02$ & $1.09 \mathrm{E}-04$ & $1.67 \mathrm{E}-02$ & $4.22 \mathrm{E}-03$ \\
\hline 212 & $6.58 \mathrm{E}-03$ & $3.16 \mathrm{E}-03$ & $1.36 \mathrm{E}-02$ & $1.54 \mathrm{E}-03$ & $3.00 \mathrm{E}-02$ & $1.17 \mathrm{E}-02$ \\
\hline 2013 & $6.27 \mathrm{E}-03$ & $2.62 \mathrm{E}-03$ & $1.49 \mathrm{E}-02$ & $1.57 \mathrm{E}-04$ & $1.59 \mathrm{E}-02$ & $4.17 \mathrm{E}-03$ \\
\hline 2014 & $5.97 \mathrm{E}-03$ & $2.13 \mathrm{E}-03$ & $1.66 \mathrm{E}-02$ & $1.36 \mathrm{E}-03$ & $2.87 \mathrm{E}-02$ & $1.13 \mathrm{E}-02$ \\
\hline
\end{tabular}


Table 17. Plot data for Figure 9, standby TDP start demands trend.

\begin{tabular}{ccccccccc}
\hline & & & \multicolumn{2}{c}{ Regression Curve Data Points } & \multicolumn{2}{c}{ Yearly Estimate Data Points } \\
\cline { 6 - 9 } FY & Demands & $\begin{array}{c}\text { Reactor } \\
\text { Years }\end{array}$ & Mean & $\begin{array}{c}\text { Lower } \\
\mathbf{( 5 \% )}\end{array}$ & $\begin{array}{c}\text { Upper } \\
\mathbf{( 9 5 \% )}\end{array}$ & $\begin{array}{c}\text { Lower } \\
\mathbf{( 5 \% )}\end{array}$ & $\begin{array}{c}\text { Upper } \\
\mathbf{( 9 5 \% )}\end{array}$ & Mean \\
\hline 1998 & 1,538 & 97.0 & & & & $1.52 \mathrm{E}+01$ & $1.65 \mathrm{E}+01$ & $1.59 \mathrm{E}+01$ \\
\hline 1999 & 1,425 & 97.0 & & & & $1.41 \mathrm{E}+01$ & $1.53 \mathrm{E}+01$ & $1.47 \mathrm{E}+01$ \\
\hline 2000 & 1,473 & 97.3 & & & & $1.45 \mathrm{E}+01$ & $1.58 \mathrm{E}+01$ & $1.51 \mathrm{E}+01$ \\
\hline 2001 & 1,381 & 97.0 & & & & $1.36 \mathrm{E}+01$ & $1.49 \mathrm{E}+01$ & $1.42 \mathrm{E}+01$ \\
\hline 2002 & 1,403 & 97.0 & & & & $1.38 \mathrm{E}+01$ & $1.51 \mathrm{E}+01$ & $1.45 \mathrm{E}+01$ \\
\hline 2003 & 1,541 & 97.0 & & & & $1.52 \mathrm{E}+01$ & $1.66 \mathrm{E}+01$ & $1.59 \mathrm{E}+01$ \\
\hline 2004 & 1,466 & 97.3 & & & & $1.44 \mathrm{E}+01$ & $1.57 \mathrm{E}+01$ & $1.51 \mathrm{E}+01$ \\
\hline 2005 & 1,492 & 97.0 & $1.50 \mathrm{E}+01$ & $1.43 \mathrm{E}+01$ & $1.57 \mathrm{E}+01$ & $1.47 \mathrm{E}+01$ & $1.61 \mathrm{E}+01$ & $1.54 \mathrm{E}+01$ \\
\hline 2006 & 1,453 & 97.0 & $1.51 \mathrm{E}+01$ & $1.45 \mathrm{E}+01$ & $1.58 \mathrm{E}+01$ & $1.43 \mathrm{E}+01$ & $1.56 \mathrm{E}+01$ & $1.50 \mathrm{E}+01$ \\
\hline 2007 & 1,468 & 97.4 & $1.53 \mathrm{E}+01$ & $1.48 \mathrm{E}+01$ & $1.58 \mathrm{E}+01$ & $1.44 \mathrm{E}+01$ & $1.57 \mathrm{E}+01$ & $1.51 \mathrm{E}+01$ \\
\hline 2008 & 1,451 & 98.3 & $1.55 \mathrm{E}+01$ & $1.50 \mathrm{E}+01$ & $1.59 \mathrm{E}+01$ & $1.41 \mathrm{E}+01$ & $1.54 \mathrm{E}+01$ & $1.48 \mathrm{E}+01$ \\
\hline 2009 & 1,547 & 98.0 & $1.56 \mathrm{E}+01$ & $1.52 \mathrm{E}+01$ & $1.60 \mathrm{E}+01$ & $1.51 \mathrm{E}+01$ & $1.65 \mathrm{E}+01$ & $1.58 \mathrm{E}+01$ \\
\hline 2010 & 1,608 & 98.0 & $1.58 \mathrm{E}+01$ & $1.54 \mathrm{E}+01$ & $1.62 \mathrm{E}+01$ & $1.57 \mathrm{E}+01$ & $1.71 \mathrm{E}+01$ & $1.64 \mathrm{E}+01$ \\
\hline 2011 & 1,595 & 98.0 & $1.59 \mathrm{E}+01$ & $1.55 \mathrm{E}+01$ & $1.64 \mathrm{E}+01$ & $1.56 \mathrm{E}+01$ & $1.70 \mathrm{E}+01$ & $1.63 \mathrm{E}+01$ \\
\hline 2012 & 1,514 & 98.3 & $1.61 \mathrm{E}+01$ & $1.55 \mathrm{E}+01$ & $1.66 \mathrm{E}+01$ & $1.48 \mathrm{E}+01$ & $1.61 \mathrm{E}+01$ & $1.54 \mathrm{E}+01$ \\
\hline 2013 & 1,622 & 96.6 & $1.62 \mathrm{E}+01$ & $1.56 \mathrm{E}+01$ & $1.69 \mathrm{E}+01$ & $1.61 \mathrm{E}+01$ & $1.75 \mathrm{E}+01$ & $1.68 \mathrm{E}+01$ \\
\hline 2014 & 1,513 & 94.0 & $1.64 \mathrm{E}+01$ & $1.56 \mathrm{E}+01$ & $1.72 \mathrm{E}+01$ & $1.54 \mathrm{E}+01$ & $1.68 \mathrm{E}+01$ & $1.61 \mathrm{E}+01$ \\
\hline Total & 25,491 & $1,652.0$ & & & & & & \\
\hline
\end{tabular}


Table 18. Plot data for Figure 10, standby TDP run $\leq 1$ hour run-hours trend.

\begin{tabular}{|c|c|c|c|c|c|c|c|c|}
\hline \multirow[b]{2}{*}{ FY } & \multirow[b]{2}{*}{ Hours } & \multirow[b]{2}{*}{$\begin{array}{c}\text { Reactor } \\
\text { Years }\end{array}$} & \multicolumn{3}{|c|}{ Regression Curve Data Points } & \multicolumn{3}{|c|}{ Yearly Estimate Data Points } \\
\hline & & & Mean & $\begin{array}{c}\text { Lower } \\
\text { (5\%) }\end{array}$ & $\begin{array}{l}\text { Upper } \\
(95 \%)\end{array}$ & $\begin{array}{c}\text { Lower } \\
(5 \%)\end{array}$ & $\begin{array}{l}\text { Upper } \\
(95 \%)\end{array}$ & Mean \\
\hline 1998 & 1,538 & 97.0 & & & & $1.52 \mathrm{E}+01$ & $1.65 E+01$ & $1.59 \mathrm{E}+01$ \\
\hline 1999 & 1,425 & 97.0 & & & & $1.41 \mathrm{E}+01$ & $1.53 \mathrm{E}+01$ & $1.47 E+01$ \\
\hline 2000 & 1,473 & 97.3 & & & & $1.45 E+01$ & $1.58 \mathrm{E}+01$ & $1.51 \mathrm{E}+01$ \\
\hline 2001 & 1,381 & 97.0 & & & & $1.36 \mathrm{E}+01$ & $1.49 \mathrm{E}+01$ & $1.42 E+01$ \\
\hline 2002 & 1,403 & 97.0 & & & & $1.38 \mathrm{E}+01$ & $1.51 \mathrm{E}+01$ & $1.45 E+01$ \\
\hline 2003 & 1,541 & 97.0 & & & & $1.52 \mathrm{E}+01$ & $1.66 \mathrm{E}+01$ & $1.59 E+01$ \\
\hline 2004 & 1,466 & 97.3 & & & & $1.44 \mathrm{E}+01$ & $1.57 E+01$ & $1.51 \mathrm{E}+01$ \\
\hline 2005 & 1,492 & 97.0 & $1.50 \mathrm{E}+01$ & $1.43 E+01$ & $1.57 \mathrm{E}+01$ & $1.47 \mathrm{E}+01$ & $1.61 \mathrm{E}+01$ & $1.54 \mathrm{E}+01$ \\
\hline 2006 & 1,453 & 97.0 & $1.51 \mathrm{E}+01$ & $1.45 E+01$ & $1.58 \mathrm{E}+01$ & $1.43 E+01$ & $1.56 \mathrm{E}+01$ & $1.50 E+01$ \\
\hline 2007 & 1,468 & 97.4 & $1.53 E+01$ & $1.48 \mathrm{E}+01$ & $1.58 \mathrm{E}+01$ & $1.44 \mathrm{E}+01$ & $1.57 \mathrm{E}+01$ & $1.51 \mathrm{E}+01$ \\
\hline 2008 & 1,451 & 98.3 & $1.55 \mathrm{E}+01$ & $1.50 \mathrm{E}+01$ & $1.59 \mathrm{E}+01$ & $1.41 \mathrm{E}+01$ & $1.54 \mathrm{E}+01$ & $1.48 \mathrm{E}+01$ \\
\hline 2009 & 1,547 & 98.0 & $1.56 \mathrm{E}+01$ & $1.52 \mathrm{E}+01$ & $1.60 E+01$ & $1.51 \mathrm{E}+01$ & $1.65 E+01$ & $1.58 E+01$ \\
\hline 2010 & 1,608 & 98.0 & $1.58 \mathrm{E}+01$ & $1.54 \mathrm{E}+01$ & $1.62 \mathrm{E}+01$ & $1.57 \mathrm{E}+01$ & $1.71 \mathrm{E}+01$ & $1.64 E+01$ \\
\hline 2011 & 1,595 & 98.0 & $1.59 \mathrm{E}+01$ & $1.55 \mathrm{E}+01$ & $1.64 \mathrm{E}+01$ & $1.56 \mathrm{E}+01$ & $1.70 \mathrm{E}+01$ & $1.63 E+01$ \\
\hline 2012 & 1,514 & 98.3 & $1.61 \mathrm{E}+01$ & $1.55 \mathrm{E}+01$ & $1.66 \mathrm{E}+01$ & $1.48 \mathrm{E}+01$ & $1.61 \mathrm{E}+01$ & $1.54 \mathrm{E}+01$ \\
\hline 2013 & 1,622 & 96.6 & $1.62 E+01$ & $1.56 \mathrm{E}+01$ & $1.69 \mathrm{E}+01$ & $1.61 \mathrm{E}+01$ & $1.75 E+01$ & $1.68 E+01$ \\
\hline 2014 & 1,513 & 94.0 & $1.64 \mathrm{E}+01$ & $1.56 \mathrm{E}+01$ & $1.72 \mathrm{E}+01$ & $1.54 \mathrm{E}+01$ & $1.68 E+01$ & $1.61 \mathrm{E}+01$ \\
\hline Total & 25,491 & $1,652.0$ & & & & & & \\
\hline
\end{tabular}


Table 19. Plot data for Figure 11, standby TDP run $>1$ hour run-hours trend.

\begin{tabular}{|c|c|c|c|c|c|c|c|c|}
\hline \multirow[b]{2}{*}{ FY } & \multirow[b]{2}{*}{$\begin{array}{l}\text { Run } \\
\text { Hours }\end{array}$} & \multirow[b]{2}{*}{$\begin{array}{c}\text { Reactor } \\
\text { Years }\end{array}$} & \multicolumn{3}{|c|}{ Regression Curve Data Points } & \multicolumn{3}{|c|}{ Yearly Estimate Data Points } \\
\hline & & & Mean & $\begin{array}{c}\text { Lower } \\
(5 \%)\end{array}$ & $\begin{array}{l}\text { Upper } \\
(95 \%)\end{array}$ & $\begin{array}{c}\text { Lower } \\
(5 \%)\end{array}$ & $\begin{array}{l}\text { Upper } \\
(95 \%)\end{array}$ & Mean \\
\hline 1998 & 420 & 97.0 & & & & $3.99 E+00$ & $4.70 \mathrm{E}+00$ & $4.33 E+00$ \\
\hline 1999 & 2,590 & 97.0 & & & & $2.58 \mathrm{E}+01$ & $2.75 E+01$ & 2.67E+01 \\
\hline 2000 & 605 & 97.3 & & & & $5.80 E+00$ & $6.64 \mathrm{E}+00$ & $6.21 E+00$ \\
\hline 2001 & 674 & 97.0 & & & & $6.51 \mathrm{E}+00$ & $7.40 \mathrm{E}+00$ & $6.95 \mathrm{E}+00$ \\
\hline 2002 & 1,243 & 97.0 & & & & $1.22 \mathrm{E}+01$ & $1.34 \mathrm{E}+01$ & $1.28 \mathrm{E}+01$ \\
\hline 2003 & 1,516 & 97.0 & & & & $1.50 \mathrm{E}+01$ & $1.63 E+01$ & $1.56 \mathrm{E}+01$ \\
\hline 2004 & 370 & 97.3 & & & & $3.49 \mathrm{E}+00$ & $4.15 E+00$ & $3.80 \mathrm{E}+00$ \\
\hline 2005 & 281 & 97.0 & $2.88 \mathrm{E}+00$ & $2.30 \mathrm{E}+00$ & $3.60 E+00$ & $2.62 E+00$ & $3.20 E+00$ & $2.90 \mathrm{E}+00$ \\
\hline 2006 & 256 & 97.0 & $2.96 \mathrm{E}+00$ & $2.45 \mathrm{E}+00$ & $3.59 E+00$ & $2.37 E+00$ & $2.92 \mathrm{E}+00$ & $2.64 \mathrm{E}+00$ \\
\hline 2007 & 268 & 97.4 & $3.05 E+00$ & $2.60 \mathrm{E}+00$ & $3.59 E+00$ & $2.48 E+00$ & $3.05 E+00$ & $2.75 \mathrm{E}+00$ \\
\hline 2008 & 306 & 98.3 & $3.15 \mathrm{E}+00$ & $2.75 \mathrm{E}+00$ & $3.61 \mathrm{E}+00$ & $2.83 E+00$ & $3.42 \mathrm{E}+00$ & $3.11 \mathrm{E}+00$ \\
\hline 2009 & 365 & 98.0 & $3.24 \mathrm{E}+00$ & $2.88 \mathrm{E}+00$ & $3.66 E+00$ & $3.41 \mathrm{E}+00$ & $4.07 E+00$ & $3.73 E+00$ \\
\hline 2010 & 356 & 98.0 & $3.34 \mathrm{E}+00$ & $2.97 \mathrm{E}+00$ & $3.76 E+00$ & $3.32 \mathrm{E}+00$ & $3.96 \mathrm{E}+00$ & $3.63 E+00$ \\
\hline 2011 & 427 & 98.0 & $3.44 \mathrm{E}+00$ & $3.03 E+00$ & $3.91 E+00$ & $4.01 \mathrm{E}+00$ & $4.71 \mathrm{E}+00$ & $4.35 \mathrm{E}+00$ \\
\hline 2012 & 297 & 98.3 & $3.55 \mathrm{E}+00$ & $3.06 \mathrm{E}+00$ & $4.12 E+00$ & $2.74 \mathrm{E}+00$ & $3.32 \mathrm{E}+00$ & $3.02 E+00$ \\
\hline 2013 & 386 & 96.6 & $3.66 \mathrm{E}+00$ & $3.07 E+00$ & $4.36 E+00$ & $3.66 \mathrm{E}+00$ & $4.34 \mathrm{E}+00$ & $3.99 E+00$ \\
\hline 2014 & 300 & 94.0 & $3.77 E+00$ & $3.06 \mathrm{E}+00$ & $4.65 E+00$ & $2.89 \mathrm{E}+00$ & $3.51 \mathrm{E}+00$ & $3.19 E+00$ \\
\hline Total & 10,660 & $1,652.0$ & & & & & & \\
\hline
\end{tabular}


Table 20. Plot data for Figure 12, standby TDP FTS events trend.

\begin{tabular}{ccccccccc}
\hline & & & \multicolumn{2}{c}{ Regression Curve Data Points } & \multicolumn{2}{c}{ Yearly Estimate Data Points } \\
\cline { 6 - 9 } FY & Failures & $\begin{array}{c}\text { Reactor } \\
\text { Years }\end{array}$ & Mean & $\begin{array}{c}\text { Lower } \\
\mathbf{( 5 \% )}\end{array}$ & $\begin{array}{c}\text { Upper } \\
\mathbf{( 9 5 \% )}\end{array}$ & $\begin{array}{c}\text { Lower } \\
\mathbf{( 5 \% )}\end{array}$ & $\begin{array}{c}\text { Upper } \\
\mathbf{( 9 5 \% )}\end{array}$ & Mean \\
\hline 1998 & 2 & 97.0 & & & & $5.59 \mathrm{E}-03$ & $6.87 \mathrm{E}-02$ & $2.44 \mathrm{E}-02$ \\
1999 & 19 & 97.0 & & & & $1.25 \mathrm{E}-01$ & $2.78 \mathrm{E}-01$ & $1.90 \mathrm{E}-01$ \\
\hline 2000 & 17 & 97.3 & & & & $1.09 \mathrm{E}-01$ & $2.54 \mathrm{E}-01$ & $1.71 \mathrm{E}-01$ \\
\hline 2001 & 5 & 97.0 & & & & $2.23 \mathrm{E}-02$ & $1.09 \mathrm{E}-01$ & $5.37 \mathrm{E}-02$ \\
\hline 2002 & 5 & 97.0 & & & & $2.23 \mathrm{E}-02$ & $1.09 \mathrm{E}-01$ & $5.37 \mathrm{E}-02$ \\
\hline 2003 & 8 & 97.0 & & & & $4.24 \mathrm{E}-02$ & $1.47 \mathrm{E}-01$ & $8.30 \mathrm{E}-02$ \\
\hline 2004 & 10 & 97.3 & & & & $5.65 \mathrm{E}-02$ & $1.71 \mathrm{E}-01$ & $1.02 \mathrm{E}-01$ \\
\hline 2005 & 8 & 97.0 & $8.25 \mathrm{E}-02$ & $4.93 \mathrm{E}-02$ & $1.38 \mathrm{E}-01$ & $4.24 \mathrm{E}-02$ & $1.47 \mathrm{E}-01$ & $8.30 \mathrm{E}-02$ \\
\hline 2006 & 6 & 97.0 & $8.37 \mathrm{E}-02$ & $5.40 \mathrm{E}-02$ & $1.30 \mathrm{E}-01$ & $2.88 \mathrm{E}-02$ & $1.22 \mathrm{E}-01$ & $6.35 \mathrm{E}-02$ \\
\hline 2007 & 9 & 97.4 & $8.50 \mathrm{E}-02$ & $5.88 \mathrm{E}-02$ & $1.23 \mathrm{E}-01$ & $4.92 \mathrm{E}-02$ & $1.59 \mathrm{E}-01$ & $9.25 \mathrm{E}-02$ \\
\hline 2008 & 8 & 98.3 & $8.62 \mathrm{E}-02$ & $6.31 \mathrm{E}-02$ & $1.18 \mathrm{E}-01$ & $4.18 \mathrm{E}-02$ & $1.45 \mathrm{E}-01$ & $8.20 \mathrm{E}-02$ \\
\hline 2009 & 15 & 98.0 & $8.75 \mathrm{E}-02$ & $6.62 \mathrm{E}-02$ & $1.16 \mathrm{E}-01$ & $9.33 \mathrm{E}-02$ & $2.29 \mathrm{E}-01$ & $1.50 \mathrm{E}-01$ \\
\hline 2010 & 10 & 98.0 & $8.88 \mathrm{E}-02$ & $6.74 \mathrm{E}-02$ & $1.17 \mathrm{E}-01$ & $5.61 \mathrm{E}-02$ & $1.70 \mathrm{E}-01$ & $1.02 \mathrm{E}-01$ \\
\hline 2011 & 7 & 98.0 & $9.01 \mathrm{E}-02$ & $6.65 \mathrm{E}-02$ & $1.22 \mathrm{E}-01$ & $3.51 \mathrm{E}-02$ & $1.33 \mathrm{E}-01$ & $7.26 \mathrm{E}-02$ \\
\hline 2012 & 8 & 98.3 & $9.14 \mathrm{E}-02$ & $6.40 \mathrm{E}-02$ & $1.31 \mathrm{E}-01$ & $4.18 \mathrm{E}-02$ & $1.45 \mathrm{E}-01$ & $8.20 \mathrm{E}-02$ \\
\hline 2013 & 5 & 96.6 & $9.28 \mathrm{E}-02$ & $6.07 \mathrm{E}-02$ & $1.42 \mathrm{E}-01$ & $2.24 \mathrm{E}-02$ & $1.10 \mathrm{E}-01$ & $5.39 \mathrm{E}-02$ \\
\hline 2014 & 14 & 94.0 & $9.42 \mathrm{E}-02$ & $5.71 \mathrm{E}-02$ & $1.55 \mathrm{E}-01$ & $8.91 \mathrm{E}-02$ & $2.26 \mathrm{E}-01$ & $1.46 \mathrm{E}-01$ \\
\hline Total & 156 & $1,652.0$ & & & & & & \\
\hline
\end{tabular}


Table 21. Plot data for Figure 13, standby TDP FTR $\leq 1 H$ events trend.

\begin{tabular}{ccccccccc}
\hline & & & \multicolumn{2}{c}{ Regression Curve Data Points } & \multicolumn{2}{c}{ Yearly Estimate Data Points } \\
\cline { 6 - 8 } FY & Failures & $\begin{array}{c}\text { Reactor } \\
\text { Years }\end{array}$ & Mean & $\begin{array}{c}\text { Lower } \\
\mathbf{( 5 \% )}\end{array}$ & $\begin{array}{c}\text { Upper } \\
\mathbf{( 9 5 \% )}\end{array}$ & $\begin{array}{c}\text { Lower } \\
\mathbf{( 5 \% )}\end{array}$ & $\begin{array}{c}\text { Upper } \\
\mathbf{( 9 5 \% )}\end{array}$ & Mean \\
\hline 1998 & 2 & 97.0 & & & & $5.07 \mathrm{E}-03$ & $6.23 \mathrm{E}-02$ & $2.21 \mathrm{E}-02$ \\
\hline 1999 & 4 & 97.0 & & & & $1.47 \mathrm{E}-02$ & $8.71 \mathrm{E}-02$ & $3.98 \mathrm{E}-02$ \\
\hline 2000 & 6 & 97.3 & & & & $2.60 \mathrm{E}-02$ & $1.10 \mathrm{E}-01$ & $5.74 \mathrm{E}-02$ \\
2001 & 6 & 97.0 & & & & $2.61 \mathrm{E}-02$ & $1.11 \mathrm{E}-01$ & $5.76 \mathrm{E}-02$ \\
\hline 2002 & 3 & 97.0 & & & & $9.60 \mathrm{E}-03$ & $7.49 \mathrm{E}-02$ & $3.10 \mathrm{E}-02$ \\
2003 & 9 & 97.0 & & & & $4.48 \mathrm{E}-02$ & $1.45 \mathrm{E}-01$ & $8.41 \mathrm{E}-02$ \\
\hline 2004 & 3 & 97.3 & & & & $9.57 \mathrm{E}-03$ & $7.47 \mathrm{E}-02$ & $3.09 \mathrm{E}-02$ \\
\hline 2005 & 3 & 97.0 & $4.22 \mathrm{E}-02$ & $1.43 \mathrm{E}-02$ & $1.24 \mathrm{E}-01$ & $9.60 \mathrm{E}-03$ & $7.49 \mathrm{E}-02$ & $3.10 \mathrm{E}-02$ \\
\hline 2006 & 1 & 97.0 & $3.68 \mathrm{E}-02$ & $1.48 \mathrm{E}-02$ & $9.12 \mathrm{E}-02$ & $1.56 \mathrm{E}-03$ & $4.90 \mathrm{E}-02$ & $1.33 \mathrm{E}-02$ \\
\hline 2007 & 6 & 97.4 & $3.21 \mathrm{E}-02$ & $1.49 \mathrm{E}-02$ & $6.90 \mathrm{E}-02$ & $2.60 \mathrm{E}-02$ & $1.10 \mathrm{E}-01$ & $5.74 \mathrm{E}-02$ \\
\hline 2008 & 5 & 98.3 & $2.80 \mathrm{E}-02$ & $1.43 \mathrm{E}-02$ & $5.47 \mathrm{E}-02$ & $2.00 \mathrm{E}-02$ & $9.79 \mathrm{E}-02$ & $4.82 \mathrm{E}-02$ \\
\hline 2009 & 6 & 98.0 & $2.44 \mathrm{E}-02$ & $1.27 \mathrm{E}-02$ & $4.66 \mathrm{E}-02$ & $2.59 \mathrm{E}-02$ & $1.10 \mathrm{E}-01$ & $5.70 \mathrm{E}-02$ \\
\hline 2010 & 2 & 98.0 & $2.12 \mathrm{E}-02$ & $1.05 \mathrm{E}-02$ & $4.29 \mathrm{E}-02$ & $5.03 \mathrm{E}-03$ & $6.17 \mathrm{E}-02$ & $2.19 \mathrm{E}-02$ \\
\hline 2011 & 4 & 98.0 & $1.85 \mathrm{E}-02$ & $8.15 \mathrm{E}-03$ & $4.21 \mathrm{E}-02$ & $1.46 \mathrm{E}-02$ & $8.63 \mathrm{E}-02$ & $3.95 \mathrm{E}-02$ \\
\hline 2012 & 3 & 98.3 & $1.61 \mathrm{E}-02$ & $6.07 \mathrm{E}-03$ & $4.29 \mathrm{E}-02$ & $9.49 \mathrm{E}-03$ & $7.41 \mathrm{E}-02$ & $3.06 \mathrm{E}-02$ \\
\hline 2013 & 0 & 96.6 & $1.41 \mathrm{E}-02$ & $4.41 \mathrm{E}-03$ & $4.48 \mathrm{E}-02$ & $1.75 \mathrm{E}-05$ & $3.47 \mathrm{E}-02$ & $4.44 \mathrm{E}-03$ \\
\hline 2014 & 0 & 94.0 & $1.23 \mathrm{E}-02$ & $3.16 \mathrm{E}-03$ & $4.75 \mathrm{E}-02$ & $1.79 \mathrm{E}-05$ & $3.55 \mathrm{E}-02$ & $4.55 \mathrm{E}-03$ \\
\hline
\end{tabular}


Table 22. Plot data for Figure 14, standby TDP FTR $>1 \mathrm{H}$ events trend.

\begin{tabular}{|c|c|c|c|c|c|c|c|c|}
\hline \multirow[b]{2}{*}{ FY } & \multirow[b]{2}{*}{ Failures } & \multirow[b]{2}{*}{$\begin{array}{c}\text { Reactor } \\
\text { Years }\end{array}$} & \multicolumn{3}{|c|}{ Regression Curve Data Points } & \multicolumn{3}{|c|}{ Yearly Estimate Data Points } \\
\hline & & & Mean & $\begin{array}{c}\text { Lower } \\
(5 \%)\end{array}$ & $\begin{array}{l}\text { Upper } \\
(95 \%)\end{array}$ & $\begin{array}{l}\text { Lower } \\
(5 \%)\end{array}$ & $\begin{array}{l}\text { Upper } \\
(95 \%)\end{array}$ & Mean \\
\hline 1998 & 3 & 97.0 & & & & 8.98E-03 & 7.01E-02 & 2.90E-02 \\
\hline 1999 & 0 & 97.0 & & & & 1.63E-05 & $3.24 \mathrm{E}-02$ & 4.14E-03 \\
\hline 2000 & 0 & 97.3 & & & & 1.63E-05 & 3.23E-02 & 4.13E-03 \\
\hline 2001 & 1 & 97.0 & & & & 1.46E-03 & 4.59E-02 & 1.24E-02 \\
\hline 2002 & 0 & 97.0 & & & & 1.63E-05 & 3.24E-02 & 4.14E-03 \\
\hline 2003 & 0 & 97.0 & & & & 1.63E-05 & $3.24 \mathrm{E}-02$ & 4.14E-03 \\
\hline 2004 & 4 & 97.3 & & & & 1.37E-02 & 8.13E-02 & $3.72 \mathrm{E}-02$ \\
\hline 2005 & 1 & 97.0 & $1.02 E-02$ & 2.80E-03 & 3.73E-02 & $1.46 \mathrm{E}-03$ & 4.59E-02 & 1.24E-02 \\
\hline 2006 & 2 & 97.0 & 1.13E-02 & 3.75E-03 & $3.41 \mathrm{E}-02$ & 4.74E-03 & 5.83E-02 & 2.07E-02 \\
\hline 2007 & 1 & 97.4 & 1.25E-02 & 4.93E-03 & 3.17E-02 & $1.45 \mathrm{E}-03$ & 4.57E-02 & $1.24 \mathrm{E}-02$ \\
\hline 2008 & 2 & 98.3 & 1.38E-02 & 6.31E-03 & 3.03E-02 & 4.70E-03 & 5.77E-02 & $2.05 \mathrm{E}-02$ \\
\hline 2009 & 0 & 98.0 & 1.53E-02 & 7.71E-03 & 3.03E-02 & 1.62E-05 & 3.21E-02 & 4.11E-03 \\
\hline 2010 & 0 & 98.0 & 1.69E-02 & 8.81E-03 & 3.24E-02 & $1.62 \mathrm{E}-05$ & 3.21E-02 & 4.11E-03 \\
\hline 2011 & 5 & 98.0 & 1.87E-02 & 9.31E-03 & 3.75E-02 & 1.88E-02 & 9.19E-02 & 4.52E-02 \\
\hline 2012 & 4 & 98.3 & 2.07E-02 & 9.23E-03 & 4.63E-02 & 1.36E-02 & 8.06E-02 & 3.69E-02 \\
\hline 2013 & 3 & 96.6 & 2.29E-02 & 8.77E-03 & 5.95E-02 & 9.01E-03 & 7.03E-02 & 2.91E-02 \\
\hline 2014 & 2 & 94.0 & 2.53E-02 & 8.12E-03 & 7.86E-02 & 4.87E-03 & 5.97E-02 & $2.12 \mathrm{E}-02$ \\
\hline Total & 28 & $1,652.0$ & & & & & & \\
\hline
\end{tabular}


Table 23. Plot data for Figure 15, normally running TDP start demands trend.

\begin{tabular}{|c|c|c|c|c|c|c|c|c|}
\hline \multirow[b]{2}{*}{ FY } & \multirow[b]{2}{*}{ Demands } & \multirow[b]{2}{*}{$\begin{array}{c}\text { Reactor } \\
\text { Years }\end{array}$} & \multicolumn{3}{|c|}{ Regression Curve Data Points } & \multicolumn{3}{|c|}{ Yearly Estimate Data Points } \\
\hline & & & Mean & $\begin{array}{c}\text { Lower } \\
(5 \%)\end{array}$ & $\begin{array}{l}\text { Upper } \\
(95 \%)\end{array}$ & $\begin{array}{l}\text { Lower } \\
(5 \%)\end{array}$ & $\begin{array}{l}\text { Upper } \\
(95 \%)\end{array}$ & Mean \\
\hline 1998 & 77 & 20.0 & & & & $3.17 E+00$ & $4.66 \mathrm{E}+00$ & $3.86 \mathrm{E}+00$ \\
\hline 1999 & 79 & 20.0 & & & & $3.24 \mathrm{E}+00$ & $4.74 \mathrm{E}+00$ & $3.94 \mathrm{E}+0 \mathrm{C}$ \\
\hline 2000 & 79 & 20.1 & & & & $3.23 E+00$ & $4.73 \mathrm{E}+00$ & $3.92 \mathrm{E}+0 \mathrm{C}$ \\
\hline 2001 & 78 & 20.0 & & & & $3.21 E+00$ & $4.71 \mathrm{E}+00$ & $3.91 \mathrm{E}+0 \mathrm{C}$ \\
\hline 2002 & 78 & 20.0 & & & & $3.21 E+00$ & $4.71 \mathrm{E}+00$ & $3.91 \mathrm{E}+0 \mathrm{C}$ \\
\hline 2003 & 78 & 20.0 & & & & $3.20 E+00$ & $4.70 \mathrm{E}+00$ & $3.89 E+0 C$ \\
\hline 2004 & 78 & 20.1 & & & & $3.20 \mathrm{E}+00$ & $4.69 \mathrm{E}+00$ & $3.89 \mathrm{E}+00$ \\
\hline 2005 & 78 & 20.0 & $3.92 E+00$ & $3.88 E+00$ & $3.97 E+00$ & $3.21 \mathrm{E}+00$ & $4.71 \mathrm{E}+00$ & $3.91 \mathrm{E}+0 \mathrm{C}$ \\
\hline 2006 & 78 & 20.0 & $3.91 E+00$ & $3.87 E+00$ & $3.95 E+00$ & $3.21 E+00$ & $4.72 \mathrm{E}+00$ & $3.91 \mathrm{E}+00$ \\
\hline 2007 & 78 & 20.0 & $3.89 E+00$ & $3.86 E+00$ & $3.92 E+00$ & $3.21 E+00$ & $4.72 \mathrm{E}+00$ & $3.91 \mathrm{E}+0 \mathrm{C}$ \\
\hline 2008 & 78 & 20.1 & $3.88 E+00$ & $3.85 E+00$ & $3.90 E+00$ & $3.20 \mathrm{E}+00$ & $4.70 \mathrm{E}+00$ & $3.89 E+00$ \\
\hline 2009 & 78 & 20.0 & $3.86 E+00$ & $3.84 E+00$ & $3.88 E+00$ & $3.21 E+00$ & $4.71 \mathrm{E}+00$ & $3.90 E+00$ \\
\hline 2010 & 76 & 20.0 & $3.84 \mathrm{E}+00$ & $3.82 E+00$ & $3.87 E+00$ & $3.11 E+00$ & $4.59 \mathrm{E}+00$ & $3.79 \mathrm{E}+00$ \\
\hline 2011 & 76 & 20.0 & $3.83 E+00$ & $3.80 E+00$ & $3.85 E+00$ & $3.12 E+00$ & $4.60 \mathrm{E}+00$ & $3.80 \mathrm{E}+0 \mathrm{C}$ \\
\hline 2012 & 76 & 20.1 & $3.81 E+00$ & $3.78 E+00$ & $3.84 E+00$ & $3.11 E+00$ & $4.58 \mathrm{E}+00$ & $3.79 \mathrm{E}+00$ \\
\hline 2013 & 76 & 20.0 & $3.80 E+00$ & $3.76 \mathrm{E}+00$ & $3.83 E+00$ & $3.12 E+00$ & $4.60 \mathrm{E}+00$ & $3.80 \mathrm{E}+0 \mathrm{C}$ \\
\hline 2014 & 76 & 20.0 & $3.78 \mathrm{E}+00$ & $3.74 \mathrm{E}+00$ & $3.82 E+00$ & $3.12 E+00$ & $4.60 \mathrm{E}+00$ & $3.81 \mathrm{E}+00$ \\
\hline Total & 1,317 & 340.2 & & & & & & \\
\hline
\end{tabular}


Table 24. Plot data for Figure 16, normally running TDP run hours trend.

\begin{tabular}{|c|c|c|c|c|c|c|c|c|}
\hline \multirow[b]{2}{*}{ FY } & \multirow[b]{2}{*}{$\begin{array}{l}\text { Run } \\
\text { Hours }\end{array}$} & \multirow[b]{2}{*}{$\begin{array}{c}\text { Reactor } \\
\text { Years }\end{array}$} & \multicolumn{3}{|c|}{ Regression Curve Data Points } & \multicolumn{3}{|c|}{ Yearly Estimate Data Points } \\
\hline & & & Mean & $\begin{array}{c}\text { Lower } \\
\text { (5\%) }\end{array}$ & $\begin{array}{l}\text { Upper } \\
(95 \%)\end{array}$ & $\begin{array}{l}\text { Lower } \\
(5 \%)\end{array}$ & $\begin{array}{l}\text { Upper } \\
(95 \%)\end{array}$ & Mean \\
\hline 1998 & 331,126 & 20.0 & & & & $1.65 E+04$ & 1.66E+04 & $1.66 \mathrm{E}+04$ \\
\hline 1999 & 335,022 & 20.0 & & & & 1.67E+04 & $1.68 \mathrm{E}+04$ & $1.68 \mathrm{E}+04$ \\
\hline 2000 & 335,022 & 20.1 & & & & 1.67E+04 & $1.68 \mathrm{E}+04$ & $1.67 E+04$ \\
\hline 2001 & 335,265 & 20.0 & & & & 1.67E+04 & $1.68 \mathrm{E}+04$ & $1.68 \mathrm{E}+04$ \\
\hline 2002 & 335,432 & 20.0 & & & & 1.67E+04 & $1.68 \mathrm{E}+04$ & $1.68 \mathrm{E}+04$ \\
\hline 2003 & 335,402 & 20.0 & & & & 1.67E+04 & $1.68 \mathrm{E}+04$ & $1.68 \mathrm{E}+04$ \\
\hline 2004 & 335,432 & 20.1 & & & & $1.67 \mathrm{E}+04$ & $1.68 \mathrm{E}+04$ & 1.67E+04 \\
\hline 2005 & 335,356 & 20.0 & $1.68 \mathrm{E}+04$ & 1.67E+04 & $1.70 \mathrm{E}+04$ & $1.67 E+04$ & $1.68 \mathrm{E}+04$ & $1.68 \mathrm{E}+04$ \\
\hline 2006 & 335,448 & 20.0 & $1.68 \mathrm{E}+04$ & $1.66 \mathrm{E}+04$ & $1.69 \mathrm{E}+04$ & $1.67 E+04$ & $1.68 E+04$ & $1.68 E+04$ \\
\hline 2007 & 335,417 & 20.0 & 1.67E+04 & $1.66 \mathrm{E}+04$ & $1.68 \mathrm{E}+04$ & $1.67 \mathrm{E}+04$ & $1.68 \mathrm{E}+04$ & $1.68 \mathrm{E}+04$ \\
\hline 2008 & 335,326 & 20.1 & $1.66 \mathrm{E}+04$ & $1.65 \mathrm{E}+04$ & $1.67 \mathrm{E}+04$ & 1.67E+04 & $1.68 \mathrm{E}+04$ & 1.67E+04 \\
\hline 2009 & 335,341 & 20.0 & $1.66 \mathrm{E}+04$ & $1.65 \mathrm{E}+04$ & $1.67 \mathrm{E}+04$ & $1.67 E+04$ & $1.68 \mathrm{E}+04$ & $1.68 \mathrm{E}+04$ \\
\hline 2010 & 327,257 & 20.0 & $1.65 \mathrm{E}+04$ & $1.64 \mathrm{E}+04$ & $1.66 \mathrm{E}+04$ & $1.63 E+04$ & $1.64 \mathrm{E}+04$ & $1.64 E+04$ \\
\hline 2011 & 327,120 & 20.0 & $1.65 \mathrm{E}+04$ & $1.64 \mathrm{E}+04$ & $1.66 \mathrm{E}+04$ & $1.63 E+04$ & $1.64 \mathrm{E}+04$ & $1.64 \mathrm{E}+04$ \\
\hline 2012 & 327,226 & 20.1 & $1.64 \mathrm{E}+04$ & $1.63 \mathrm{E}+04$ & $1.65 \mathrm{E}+04$ & $1.63 E+04$ & $1.64 \mathrm{E}+04$ & $1.63 E+04$ \\
\hline 2013 & 327,044 & 20.0 & $1.63 E+04$ & $1.62 E+04$ & $1.65 \mathrm{E}+04$ & $1.63 E+04$ & $1.64 \mathrm{E}+04$ & $1.64 \mathrm{E}+04$ \\
\hline 2014 & 327,242 & 20.0 & $1.63 E+04$ & $1.61 \mathrm{E}+04$ & $1.64 \mathrm{E}+04$ & $1.63 E+04$ & $1.64 \mathrm{E}+04$ & $1.64 \mathrm{E}+04$ \\
\hline Total & $5,655,477$ & 340.2 & & & & & & \\
\hline
\end{tabular}


Table 25. Plot data for Figure 17, normally running TDP FTS events trend.

\begin{tabular}{ccccccccc}
\hline & & & \multicolumn{2}{c}{ Regression Curve Data Points } & \multicolumn{2}{c}{ Yearly Estimate Data Points } \\
\cline { 6 - 8 } FY & Failures & $\begin{array}{c}\text { Reactor } \\
\text { Years }\end{array}$ & Mean & $\begin{array}{c}\text { Lower } \\
\mathbf{( 5 \% )}\end{array}$ & $\begin{array}{c}\text { Upper } \\
\mathbf{( 9 5 \% )}\end{array}$ & $\begin{array}{c}\text { Lower } \\
\mathbf{( 5 \% )}\end{array}$ & $\begin{array}{c}\text { Upper } \\
\mathbf{( 9 5 \% )}\end{array}$ & Mean \\
\hline 1998 & 1 & 20.0 & & & & $5.28 \mathrm{E}-03$ & $1.66 \mathrm{E}-01$ & $4.50 \mathrm{E}-02$ \\
1999 & 3 & 20.0 & & & & $3.25 \mathrm{E}-02$ & $2.54 \mathrm{E}-01$ & $1.05 \mathrm{E}-01$ \\
\hline 2000 & 0 & 20.1 & & & & $5.89 \mathrm{E}-05$ & $1.17 \mathrm{E}-01$ & $1.50 \mathrm{E}-02$ \\
\hline 2001 & 1 & 20.0 & & & & $5.28 \mathrm{E}-03$ & $1.66 \mathrm{E}-01$ & $4.50 \mathrm{E}-02$ \\
\hline 2002 & 0 & 20.0 & & & & $5.90 \mathrm{E}-05$ & $1.17 \mathrm{E}-01$ & $1.50 \mathrm{E}-02$ \\
2003 & 0 & 20.0 & & & & $5.90 \mathrm{E}-05$ & $1.17 \mathrm{E}-01$ & $1.50 \mathrm{E}-02$ \\
\hline 2004 & 0 & 20.1 & & & & $5.89 \mathrm{E}-05$ & $1.17 \mathrm{E}-01$ & $1.50 \mathrm{E}-02$ \\
\hline 2005 & 3 & 20.0 & $3.61 \mathrm{E}-02$ & $1.23 \mathrm{E}-02$ & $1.06 \mathrm{E}-01$ & $3.25 \mathrm{E}-02$ & $2.54 \mathrm{E}-01$ & $1.05 \mathrm{E}-01$ \\
\hline 2006 & 0 & 20.0 & $3.42 \mathrm{E}-02$ & $1.37 \mathrm{E}-02$ & $8.54 \mathrm{E}-02$ & $5.90 \mathrm{E}-05$ & $1.17 \mathrm{E}-01$ & $1.50 \mathrm{E}-02$ \\
\hline 2007 & 1 & 20.0 & $3.24 \mathrm{E}-02$ & $1.50 \mathrm{E}-02$ & $7.00 \mathrm{E}-02$ & $5.28 \mathrm{E}-03$ & $1.66 \mathrm{E}-01$ & $4.50 \mathrm{E}-02$ \\
\hline 2008 & 0 & 20.1 & $3.07 \mathrm{E}-02$ & $1.59 \mathrm{E}-02$ & $5.92 \mathrm{E}-02$ & $5.89 \mathrm{E}-05$ & $1.17 \mathrm{E}-01$ & $1.50 \mathrm{E}-02$ \\
\hline 2009 & 1 & 20.0 & $2.91 \mathrm{E}-02$ & $1.61 \mathrm{E}-02$ & $5.26 \mathrm{E}-02$ & $5.28 \mathrm{E}-03$ & $1.66 \mathrm{E}-01$ & $4.50 \mathrm{E}-02$ \\
\hline 2010 & 0 & 20.0 & $2.76 \mathrm{E}-02$ & $1.52 \mathrm{E}-02$ & $4.99 \mathrm{E}-02$ & $5.90 \mathrm{E}-05$ & $1.17 \mathrm{E}-01$ & $1.50 \mathrm{E}-02$ \\
\hline 2011 & 0 & 20.0 & $2.61 \mathrm{E}-02$ & $1.35 \mathrm{E}-02$ & $5.06 \mathrm{E}-02$ & $5.90 \mathrm{E}-05$ & $1.17 \mathrm{E}-01$ & $1.50 \mathrm{E}-02$ \\
\hline 2012 & 1 & 20.1 & $2.47 \mathrm{E}-02$ & $1.14 \mathrm{E}-02$ & $5.38 \mathrm{E}-02$ & $5.27 \mathrm{E}-03$ & $1.66 \mathrm{E}-01$ & $4.49 \mathrm{E}-02$ \\
\hline 2013 & 0 & 20.0 & $2.34 \mathrm{E}-02$ & $9.30 \mathrm{E}-03$ & $5.91 \mathrm{E}-02$ & $5.90 \mathrm{E}-05$ & $1.17 \mathrm{E}-01$ & $1.50 \mathrm{E}-02$ \\
\hline 2014 & 1 & 20.0 & $2.22 \mathrm{E}-02$ & $7.47 \mathrm{E}-03$ & $6.60 \mathrm{E}-02$ & $5.28 \mathrm{E}-03$ & $1.66 \mathrm{E}-01$ & $4.50 \mathrm{E}-02$ \\
\hline Total & 12 & 340.2 & & & & & & \\
\hline
\end{tabular}


Table 26. Plot data for Figure 18, normally running TDP FTR events trend.

\begin{tabular}{ccccccccc}
\hline & & & \multicolumn{2}{c}{ Regression Curve Data Points } & \multicolumn{2}{c}{ Yearly Estimate Data Points } \\
\cline { 6 - 8 } FY & Failures & $\begin{array}{c}\text { Reactor } \\
\text { Years }\end{array}$ & Mean & $\begin{array}{c}\text { Lower } \\
\mathbf{( 5 \% )}\end{array}$ & $\begin{array}{c}\text { Upper } \\
\mathbf{( 9 5 \% )}\end{array}$ & $\begin{array}{c}\text { Lower } \\
\mathbf{( 5 \% )}\end{array}$ & $\begin{array}{c}\text { Upper } \\
\mathbf{( 9 5 \% )}\end{array}$ & Mean \\
\hline 1998 & 3 & 20.0 & & & & $4.82 \mathrm{E}-02$ & $3.76 \mathrm{E}-01$ & $1.56 \mathrm{E}-01$ \\
1999 & 4 & 20.0 & & & & $7.40 \mathrm{E}-02$ & $4.38 \mathrm{E}-01$ & $2.00 \mathrm{E}-01$ \\
\hline 2000 & 3 & 20.1 & & & & $4.81 \mathrm{E}-02$ & $3.76 \mathrm{E}-01$ & $1.55 \mathrm{E}-01$ \\
\hline 2001 & 4 & 20.0 & & & & $7.40 \mathrm{E}-02$ & $4.38 \mathrm{E}-01$ & $2.00 \mathrm{E}-01$ \\
\hline 2002 & 3 & 20.0 & & & & $4.82 \mathrm{E}-02$ & $3.76 \mathrm{E}-01$ & $1.56 \mathrm{E}-01$ \\
2003 & 2 & 20.0 & & & & $2.55 \mathrm{E}-02$ & $3.13 \mathrm{E}-01$ & $1.11 \mathrm{E}-01$ \\
\hline 2004 & 7 & 20.1 & & & & $1.61 \mathrm{E}-01$ & $6.12 \mathrm{E}-01$ & $3.33 \mathrm{E}-01$ \\
2005 & 5 & 20.0 & $1.79 \mathrm{E}-01$ & $1.19 \mathrm{E}-01$ & $2.69 \mathrm{E}-01$ & $1.02 \mathrm{E}-01$ & $4.98 \mathrm{E}-01$ & $2.45 \mathrm{E}-01$ \\
\hline 2006 & 3 & 20.0 & $1.82 \mathrm{E}-01$ & $1.29 \mathrm{E}-01$ & $2.58 \mathrm{E}-01$ & $4.82 \mathrm{E}-02$ & $3.76 \mathrm{E}-01$ & $1.56 \mathrm{E}-01$ \\
\hline 2007 & 3 & 20.0 & $1.85 \mathrm{E}-01$ & $1.39 \mathrm{E}-01$ & $2.48 \mathrm{E}-01$ & $4.82 \mathrm{E}-02$ & $3.76 \mathrm{E}-01$ & $1.56 \mathrm{E}-01$ \\
\hline 2008 & 3 & 20.1 & $1.89 \mathrm{E}-01$ & $1.48 \mathrm{E}-01$ & $2.42 \mathrm{E}-01$ & $4.81 \mathrm{E}-02$ & $3.76 \mathrm{E}-01$ & $1.55 \mathrm{E}-01$ \\
\hline 2009 & 3 & 20.0 & $1.92 \mathrm{E}-01$ & $1.54 \mathrm{E}-01$ & $2.39 \mathrm{E}-01$ & $4.82 \mathrm{E}-02$ & $3.76 \mathrm{E}-01$ & $1.56 \mathrm{E}-01$ \\
\hline 2010 & 6 & 20.0 & $1.96 \mathrm{E}-01$ & $1.57 \mathrm{E}-01$ & $2.43 \mathrm{E}-01$ & $1.31 \mathrm{E}-01$ & $5.56 \mathrm{E}-01$ & $2.89 \mathrm{E}-01$ \\
\hline 2011 & 4 & 20.0 & $1.99 \mathrm{E}-01$ & $1.57 \mathrm{E}-01$ & $2.53 \mathrm{E}-01$ & $7.40 \mathrm{E}-02$ & $4.38 \mathrm{E}-01$ & $2.00 \mathrm{E}-01$ \\
\hline 2012 & 4 & 20.1 & $2.03 \mathrm{E}-01$ & $1.53 \mathrm{E}-01$ & $2.68 \mathrm{E}-01$ & $7.38 \mathrm{E}-02$ & $4.37 \mathrm{E}-01$ & $2.00 \mathrm{E}-01$ \\
\hline 2013 & 6 & 20.0 & $2.06 \mathrm{E}-01$ & $1.48 \mathrm{E}-01$ & $2.88 \mathrm{E}-01$ & $1.31 \mathrm{E}-01$ & $5.56 \mathrm{E}-01$ & $2.89 \mathrm{E}-01$ \\
\hline 2014 & 3 & 20.0 & $2.10 \mathrm{E}-01$ & $1.42 \mathrm{E}-01$ & $3.11 \mathrm{E}-01$ & $4.82 \mathrm{E}-02$ & $3.76 \mathrm{E}-01$ & $1.56 \mathrm{E}-01$ \\
\hline Total & 66 & 340.2 & & & & & & \\
\hline
\end{tabular}




\section{REFERENCES}

[1] United States Nuclear Regulatory Comission, "Regulatory Assessment Performance Indicator Guideline," 31 August 2013. [Online]. Available: pbadupws.nrc.gov/docs/ML1326/ML13261A116.pdf.

[2] United States Nuclear Regulatory Commission, "Industry Trends," 12 June 2015. [Online]. Available: http://www.nrc.gov/reactors/operating/oversight/industry-trends.html\#objectives.

[3] R. L. Johnson, P. L. Lassahn, Z. R. Martinson, R. K. McCardell and D. T. Sparks, "Fuel Rod Behavior during Tests PCM 8-1 RS, CHF Scoping, and PCM 8-1 RF," NUREG/CR-1715, 1980.

[4] United States Nuclear Regulatory Commission, "Component Reliability Data Sheets Update 2010," January 2012. [Online]. Available: http://nrcoe.inl.gov/resultsdb/publicdocs/AvgPerf/ComponentReliabilityDataSheets2010.pdf.

[5] S. A. Eide, T. E. Wierman, C. D. Gentillon, D. M. Rasmuson and C. L. Atwood, "Industry-Average Performance for Components and Initiating Events at U.S. Commercial Nuclear Power Plants," NUREG/CR-6928, 2007.

[6] C. D. Gentillion, "Overview and Reference Document for Operational Experience Results and Databases Trending," February 2012. [Online]. Available: https://nrcoe.inel.gov/resultsdb/publicdocs/Overview-and-Reference.pdf.

[7] R Core Team, "R: A language and environment for statistical computing," R Core Team, Vienna, 2015.

[8] SAS Institute Inc., "SAS 9.1.3 Help and Documentation," SAS Institute Inc., Cary, 2002-2004.

[9] C. L. Atwood, J. L. LaChance, H. F. Martz, D. J. Anderson, M. Englehardt, D. Whitehead and T. Wheeler, "Handbook of Parameter Estimation for Probabilistic Risk Assessment," NUREG/CR-6823, SAND2003-3348P, 2003.

[10] J. C. Lane, "NRC Operating Experience (OpE) Programs," Office of Nuclear Regulatory Research, 15 July 2015. [Online]. Available: http://pbadupws.nrc.gov/docs/ML1518/ML15189A345.pdf. [Accessed 2015]. 